\title{
戦略的創造研究推進事業（社会技術研究開発）
}

科学技術イノベーション政策のための科学 研究開発プログラム 研究開発プロジェクト (特別枠)

\section{「先端医療を対象とした規制・技術標準整備 のための政策シミュレーション」}

（英語表記 Scenario Planning for Making Regulatory Policies and Technical Standards in Advanced Medicine)

\section{研究開発実施終了報告書}

研究開発期間 平成 25 年 10 月～平成 28 年 9 月

研究代表者 加納 信吾

所属 役職 東京大学大学院新領域創成科学研究科 准教授 


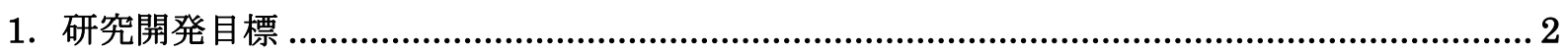

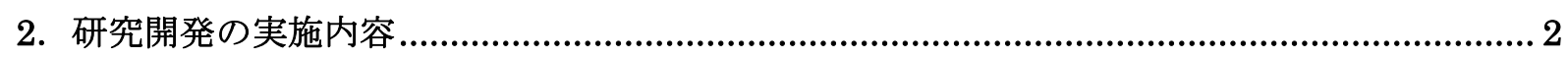

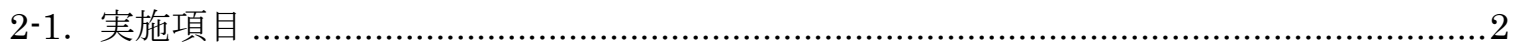

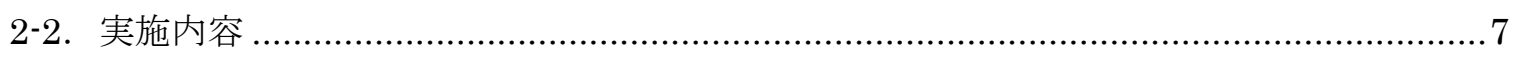

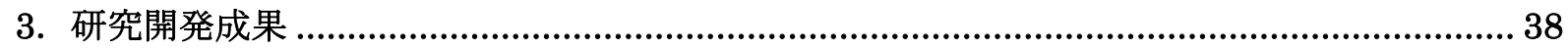

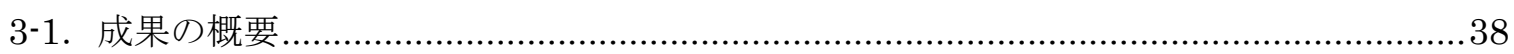

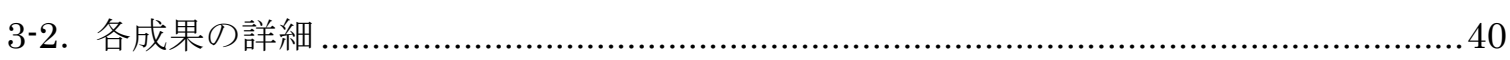

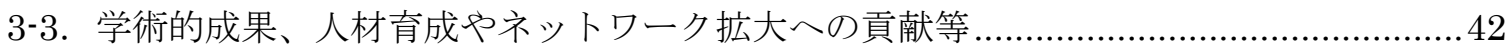

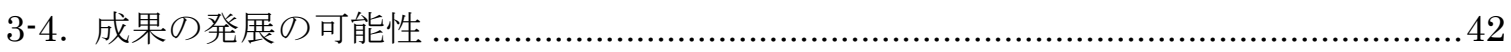

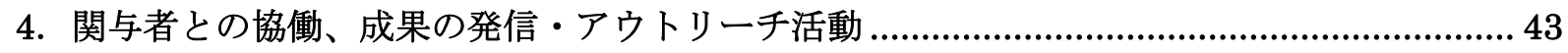

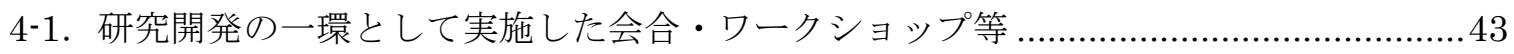

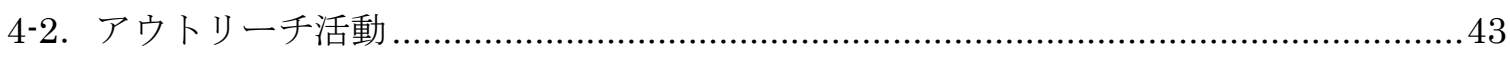

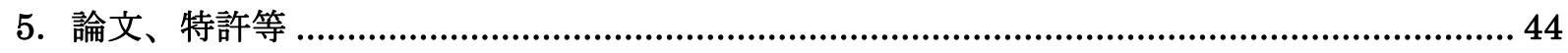

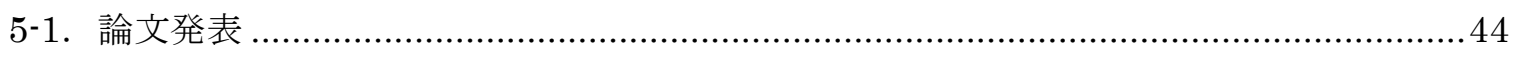

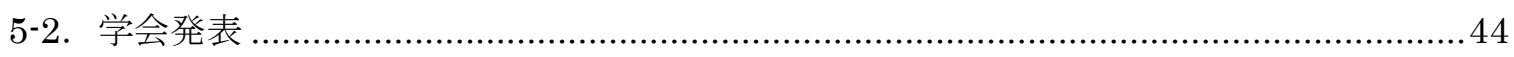

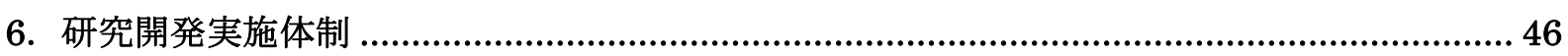

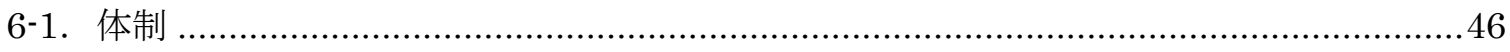

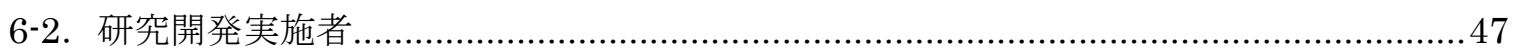

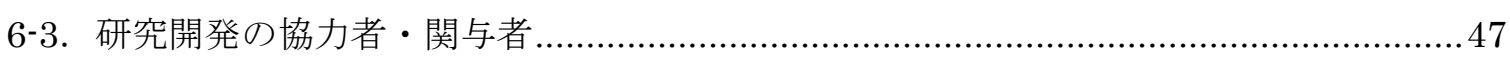




\section{1. 研究開発目標}

本プロジェクトでは、臨床応用に必要となる技術標準と規制を迅速に確立するための政策研 究・政策提案を実施すると同時に、新規政策が追加された場合のルール体系の変化をシミュレー ションする手法を提案する。ルール組成の全体プロセスを「政策バリューチェーン」として捉え、 技術開発の早期段階からのルール組成着手を実現するためのルールの研究開発促進と国際ルール 化に重点を置いた政策オプションを創出するとともに、シナリオプランニングによる政策シミュ レーション手法の実装を目指す。

\section{2. 研究開発の実施内容}

\section{2-1. 実施項目}

本プロジェクトでは、研究、実証、政策提案、社会的実装の 4 段階で設計されており、加えて セクター軸（再生医療ツール、再生医療治療、先端医療機器、個別化医療）と機能軸（ルールの 研究開発、国際ルール化、境界組織等）に分けて分析するアプローチをとっている。事例が実施 項目で重複することがあるため、本報告書では、セクター軸、機能軸で実施内容を整理し、各内 容の中で、研究(エビデンスの収集)、実証(バックワード・シナリオプランニング)、政策提案（フ オワード・シナリオプランニング）の内容を記載する。社会的実装部分は、本報告書では「3. 研究開発成果」の部分で記載する。本プロジェクトの 4 段階は、以下のように区分している(図 1)。

研究 : 個別化医療、再生医療、先端医療機器の各分野の「政策バリューチェーン」の 8 つ個別 プロセス（1)技術動向の予測、(2)ルール組成の課題認識と優先順位付け、(3)ルール設定のための 研究開発、(4)ルール組成、(5)国際ルール化（国際標準化）、(6)ルール運用組織の最適化、(7)暫定的 ルール運用、8ルール作動状態のモニタリングと修正）における事例及び改善案を収集し、各々 において「ルール複合体」と「ルール整備予想」から構成される「ルール環境」が過去にどのよ うに変遷してきたか、その中で個別プロセスがどのように実施されてきたか、また、実際の技術 の進展とルールの整備状態の間にあるギャップ状態を企業行動とともに分析し、そのギャップ状 態がどのように解消されたかに関するエビデンスの収集と分析を行い、課題を抽出する。

実証 : 研究で収集されたエビデンスに基づいて、各種イベントや環境変化を時系列に並べるロー ドマップを作成し、分野ごとに、過去のある時点から見た複数のシナリオの想定、想定し得たシ ナリオ分岐の要因、求められていた政策オプションをその時間軸的要請も含めて描き出すと同時 に実際に起きたシナリオとの差を分析する（バックワードーシナリオプランニング）。

政策提案 : 研究段階で得られたエビデンス、政策アイデアとバックワード・シナリオプランニン グでの経験に基づいて、分野ごとに将来のルール環境の予想を行い、現在の時点から未来を見て、 複数のシナリオ、シナリオ分岐の要因、求められる政策オプションを描き出す（フォワードーシ ナリオプランニング)。

社会的実装 : フォワード・シナリオプランニングに結果に基づいて、政策実装の担い手との情報 交換を行い、ルール環境の変化、シナリオ分岐の要因に関するコンセンサス形成を行い、これに 基づいて、修正された「求められる政策オプション」とそれによる将来シナリオの影響をシミュ レーションし、組織・機能設計、求められるグラントを含めた政策提案を実施するともに、シナ リオプランニングによる政策シミュレーション手法自体の政策立案プロセスへの採用を目指す。

計画段階からの修正点は、シナリオプランニングにおける主語を企業に限定せず、各々のセク 
ターの事情に合わせて、政府や境界組織とする場合も組み込んだ点にある。また、企業分析は各 セクター軸の分析の中に含めて記載している。

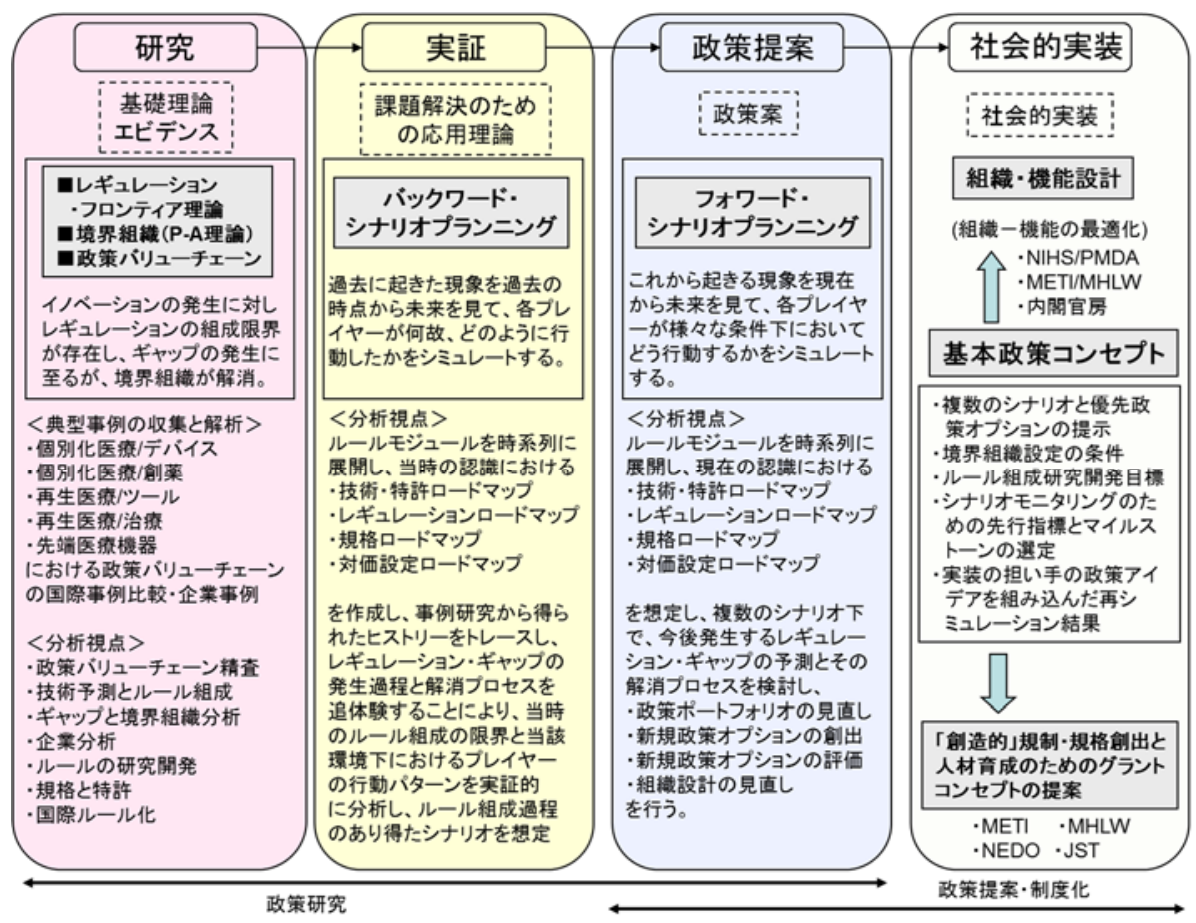

図 1 研究・実証・政策提案・社会的実装の流れ

実施項目 1. 機能軸 : レギュレーションの政策バリューチェーン

本研究の骨格をなす、レギュレーション政策のプロセスを定義するバリューチェーンの妥当性 を検討した。ルールの組成プロセスを定義する上で、国際ルールの検討から入る場合を Outside-in， 国内ルールから入る場合を Inside-out として区分して用いることとした。レギュレーション・プ ロセスとイノベーション・プロセスの相互作用を双方のプロセスを定義することにより、イノベ ーターとレギュレーターの相互作用の解析可能とするためのフレームワークを設定した。また、 海外のルール・オブ・ルールとプロセスの関係を調查した。

実施項目 2. 機能軸 : 技術予測とルール組成

日米の規制当局が実施した技術予測の事例を調查し、技術予測から優先順位付けからルールの レギュレーション・プロセスの上流からルール組成までの過程を「次世代医療機器評価指標策定 事業」の策定過程を通じて検証し、プロセスの連結状態を確認した。

\section{実施項目 3. 機能軸 : ルールの研究開発}

「ルールの研究開発」の概念を定義するとともに、イノベーターの活動からレギュレーターの 活動が開始される分離過程を検証した。マクロなアプローチとしては、テキストマイニングを用 いて、日本の再生医療のグラントの要旨からレギュレーションがどの程度進展したかを定量計測 した。ミクロなアプローチとしては、米国における人工肺チップ開発の事例分析により、評価技 術が、評価技術のためのガイドラインに適用される過程を分析した。

実施項目 4. 機能軸 : 国際ルールの組成

国際ルールは、レギュレーションの政策バリューチェーンでは常に、Outside-in 型で海外での 
合意から国内移行の形をとる。本研究では、国際ルールの組成過程について、セクター軸のグル 一プ作業として、日本が主体的に関与した例として、医薬品における不整脈防止のための

ICHS7B/E14(再生医療ツール G), DNA 知チップの精度管理のための ISO16578(個別化医療ツー ル)にて、その組成過程を分析した。また、ルール組成に関寸る国際的なイニシアティブ発揮の条 件について検討した。
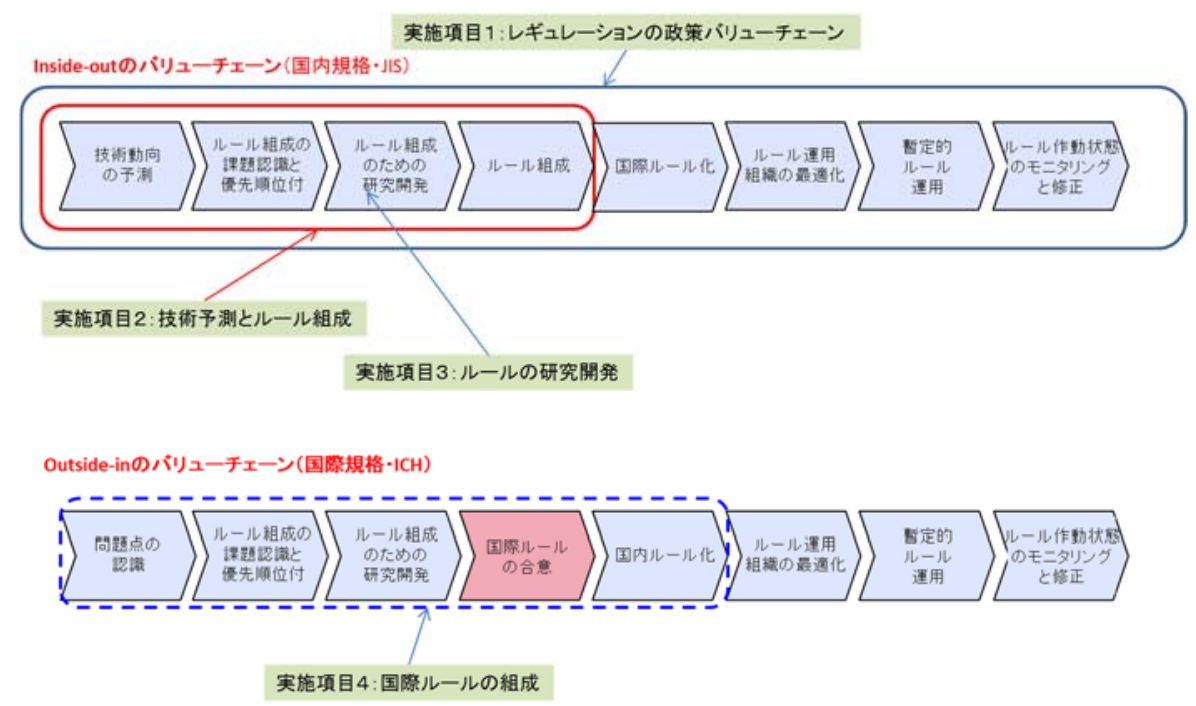

図 2 : 研究開発実施項目の位置づけ: 機能軸 $1 \sim 4$

\section{実施項目 5. 機能軸：境界組織}

イノベーターとレギュレーターを媒介する組織を「境界組織」として定義し、各分野における 重要なルールの同定とそれに関与した境界組織を同定し、その形態と機能を分析した。対象ルー ルとして、ICHS7B/E14、ISO16578、次世代医療機器評価指標を選択し、境界組織の機能と継続 性に関する分析を実施した(図 3)。

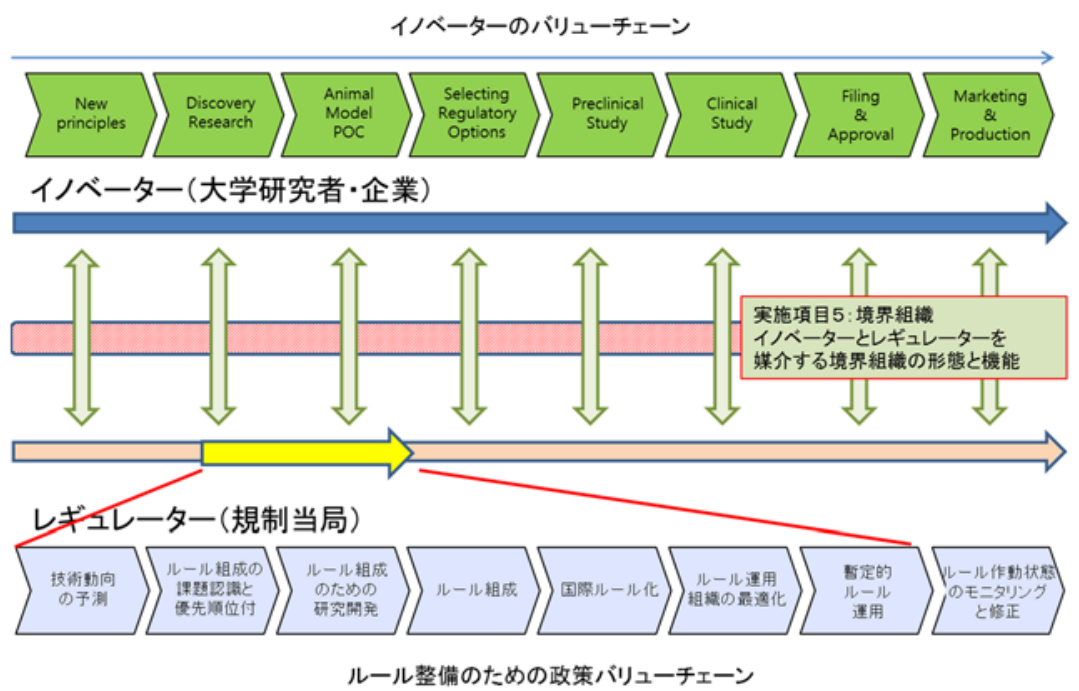

図 3 : 研究開発実施項目の位置づけ : 機能軸 : 境界組織の分析 
実施項目 6. 機能軸 : 薬事規制と技術標準のリンケージ

各国の規制当局によるガイドラインに任意規格（自国メーカー等に有利な国際規格等）が引用 されることによって、事実上の強制法規化（デファクトマンダトリー化）がなされている事例を 分析するとともに、ガイドラインに他のガイドラインや技術標準(ISO,JIS)が引用されている状態 を分析する「薬事規制と技術標準のリンケージ解析」を実施した(図 4)。

規格と特許については、実施項目 6 に統合し、ガイドラインに記載される評価項目を裏打ちす るものとしての規格と特許について検討した。

製品/サービスを取り巻く「ルールの束」/ 薬事規制と技術標準

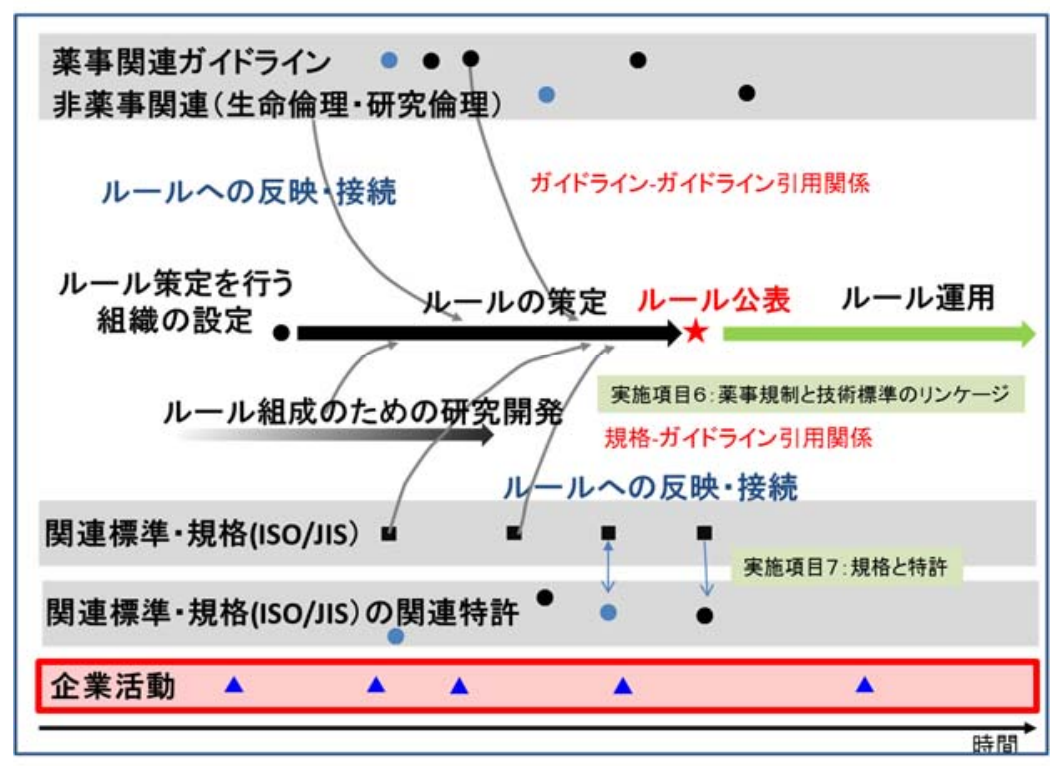

図 4 : 研究開発実施項目の位置づけ：機能軸：GL/技術標準/特許

実施項目 7. 機能軸 : リーガル・パースペクティブ

製品特異的なガイドライン整備の功罪及び 2)新規の規制整備の法的枠組みについて検討を行っ た。特に、タイムリーかつより適切な内容の規制が探求され続けるような制度設計について、主 に行政手続と行政組織の $2 つ の$ 観点から改善策の案を提示した。

実施項目 8. 政策提言の準備 : シナリオプランニングの利用に関する検討

4 回の研究会を通じて、プロジェクト参加者の Foresight 研究及びシナリオプランニング手法 に関する知識を深めると同時に、シナリオプランニング手法と政策提案の関係を整理し、政策提 案につなげるための共通フォーマットを整備した。

\section{実施項目 9. セクター軸 : 先端医療機器}

過去分析では、製品非特異的な医療機器の審査事例と製品特異的なガイドラインによる審査事 例を比較し、新規にガイドラインの整備が必要になる条件について検討した。また。評価技術の ためのガイドライン MDDT について検討した。

バックワード・シナリオプランニングでは、新規性の高い医療機器全体を対象とした全製品を カバーする分析フレームとし、(1)規制当局の新製品に対する方針（製品特異的ガイドラインを組 成するか否か) を巡る選択と(2)新しい医療機器のコンセプトの完成度により、分岐したとする過 
去シナリオを構築した。

フォワード・シナリオプランニング :「妥当な価格ロジックの構築」、「国際的なイニシアティブ と市場確保」、製品多様性に対応できるホライゾンタルルールの組成」の 3 つをシナリオ分岐と して想定した

\section{実施項目 10. セクター軸 : 再生医療（治療）}

過去事例では、成功例 4 件、失敗例 1 件を選択し、ルールマップの作成(非薬事、薬事、技術標 準)、時系列解析、境界組織分析を実施した。また、再生医療におけるガイドラインの内容につい て国際比較を実施した。

バックワード・シナリオプランニングでは、薬事法準拠か医師法準拠かの選択、規制当局との コミュニケーションの 2 つを分岐として選択し、regulatory space 上でのパスを評価した。

フォワード・シナリオプランニングでは、「保険カバー範囲」と「アプリケーション別の安全性 基準の整備」をシナリオ分岐とするシナリオを想定した

\section{実施項目 11. セクター軸 : 再生医療（ツール）}

過去事例では ICHS7B/E14（医薬品の心筋への安全性に関する国際ルール）を選択し、新規評 価技術のルール組成への組込みに関する理想モデルを構築した。

バックワード・シナリオプランニング : 理想モデルに基づいてバックワードSP を実施し、境 界組織の継続性が極めて重要でかつ不確実であり、これにより過去は分岐していたと想定した。 フォワード・シナリオプランニングでは、ICHS7B/E14の 3 週目の策定サイクルを想定し、技術 融合による次期 ICH 改定と新パラダイムの創設の 2 つのゴールについて検討した。

\section{実施項目 12. セクター軸 : 個別化医療}

過去事例では、個別化医療・ツール側では、薬事承認事例が存在する診断薬 DNA チップにつ いて、次世代医療機器評価指標（開発ガイドライン、薬事ガイドライン）及び技術標準としての ISO を選択し、詳細なルールマップの作成、時系列解析、境界組織の同定し(文献(9))、ISO マネ ジメントモデルを構築した。個別化医療・創薬側では、日本側ではルール組成のための研究開発 活動を見いだせず、米国の Voluntary Genomic Data Submission を取り上げ、分析を実施した。

バックワード・シナリオプランニングでは、日本が主導した ISO16578 を対象としたが、ISO マネジメントモデルの 9 つの要因は全てが分岐する五月雨型のシナリオとした。

フォワード・シナリオプランニングでは、「医療効率をあげるイノベーション政策」と「プライ バシーと医療費削減のトレードオフを国民が受け入れるか」の 2 つをシナリオ分岐とした。 


\section{2-2. 実施内容}

2-2-1. 機能軸 : レギュレーションの政策バリューチェーン

本研究の骨格をなす、レギュレーションとイノベーションの相互作用を分析していくためのツ ールとして、11)レギュレーション政策のプロセスを定義するバリューチェーンの妥当性を検討し、 レギュレーションのプロセスとイノベーションのプロセスの両者を並行させて分析する方法と定 期するとともに、(2)相互作用の状態を時間軸とともに分析していくために、Regulatory Space を 定義していくことにつき、検討した。

\section{1) Regulatory Space の定義問題}

ルールの制御対象となる技術領域や関与者をどう定義するかという問題は、「Regulatory Space」 の定義の問題として取り扱われ、研究者のスタンスや分析視点によって、各々異なる定義によっ て議論されてきた。例えば、Barry（2006）は、石油産業を例に、「Technological Zone」は技術 的なガイドラインや方法、形態の多様性が減じられ、共通の標準が確立された空間であり、

metrological zones（共通の測定方法）、infrastructural zones（共通の 接続基準の創出）、zones of qualification（共通の規格や評価基準によって制御対象や手順が測定された時に生じる技術空 間）の 3 つで特徴づけられるとしてルール化された技術空間を論じており、Faulker（2009）は この「Technological Zone」概念を再生医療分野での分析に適用している。Hogarth（2012）は、 ファーマコゲノミクスでの事例分析から、ルール組成の意思決定前の「準備段階の制御空間

(pre-regulatory space)」が重要であることを指摘しており、この他にも「Regulatory Space」 の捉え方としては「Biomedical Platform」(Cambrosio et al. 2006)、「ongoing, deliberative regulatory space」（Wilson-Kovacs and Hauskeller,2012）などが報告されてきた。これらの既 存研究では、個別の技術に着目し、regulatory space を論じるに際して、ルールが組成されてい る状態とルールが組成されていない状態の差をどう見るかがひとつの焦点となっているが、ルー ルが組成されないまま実用化に向かう状態（例えば、日本での医師法・医療法による細胞免疫療 法のように）や、ルールが組成されず実用化が進まない状態を含めて、どのように包括的に regulatory space を定義していくかという点が課題となっている。

\section{2）ルール組成のプロセス定義上の課題}

一方、Faulker（2009）が指摘するように「Innovation-first/regulation-after」から

$\lceil$ co-development of a regulatory arena and novel technology」への転換を考える場合に、新た なルール組成が必要であるという認識はどの段階から発生するか、また認識の発生から実際のル 一ル組成までにどのような工程を経ているかという分析は必須となる。両者のプロセスが同じで あればルール組成のパラダイム転換はどのように起こり得るのか、異なるプロセスを経るのであ れば何がプロセスに加味されるのかが検出されなければ、その違いを論じることはできない。

Hogarth(2012) の「pre-regulatory space」は、準備段階の制御空間の存在を指摘しており、従 来のプロセスに追加されたプロセスがあるという問題 提起を行っている。この観点からは彼の指 摘は、regulatory space の定義とルール組成のプロセスの両面からの 問題提起であると捉えるこ ともできるが、プロセスに違いがあるかどうかは、まず基準となる一般的なプロセス定義を行い、 これをコントロールとしてプロセス内の変化、新規プロセスの有無を観測していく必要がある。

初期段階におけるルール組成の必要性をモニタリングすることについては、「技術予測」とその 後のアクションとしての「(ルール組成の) 優先順位の設定」について、Wild ら(2008)は、エマ ージングな医療技術に対する政策的な意思決定を構成する 5 つの機能的プロセスとして、 identification (\& filtering)、prioritization、 early assessment、dissermination、monitoring を 列挙し、これを Horizon Scanning System (HSS) と概念的に定義し、欧州における「EuroScan」 
の 13 の事例を報告している。また、Wild ら(2008)は、ルール組成の優先順位についても、ルー ル組成が必要な技術分野や技術を抽出する必要性が認識しており、Markiewicz ら(2014)は、それ に適した方法についても議論が展開されている。しかし、技術予測における実現可能性評価とル ール組成の全体のプロセスをカバーした分析フレームワークは提示されていない。

3)本研究のプロセス定義

そこで、本研究では、今後求められてくるルール組成のプロセスが新しいプロセスの設定を要 するかどうかを検討するする目的も含めて、ルール組成の政策体系全体を解析対象とするため、 ルールが組成される前工程から運用・修正に至る後工程までを含めて「政策バリューチェーン」 を『(1)技術動向の予測、(2)ルール組成の課題認識と優先順位付け、(3)ルール組成のための研究開 発、(4)ルール組成、(5)国際ルール化（国際標準化）、(6)ルール運用組織の最適化、(7)暫定的ルール 運用、8ルール作動状態のモニタリングと修正、という８段階の個別プロセスを作動させる政策 体系』として定義する(図 5 )。

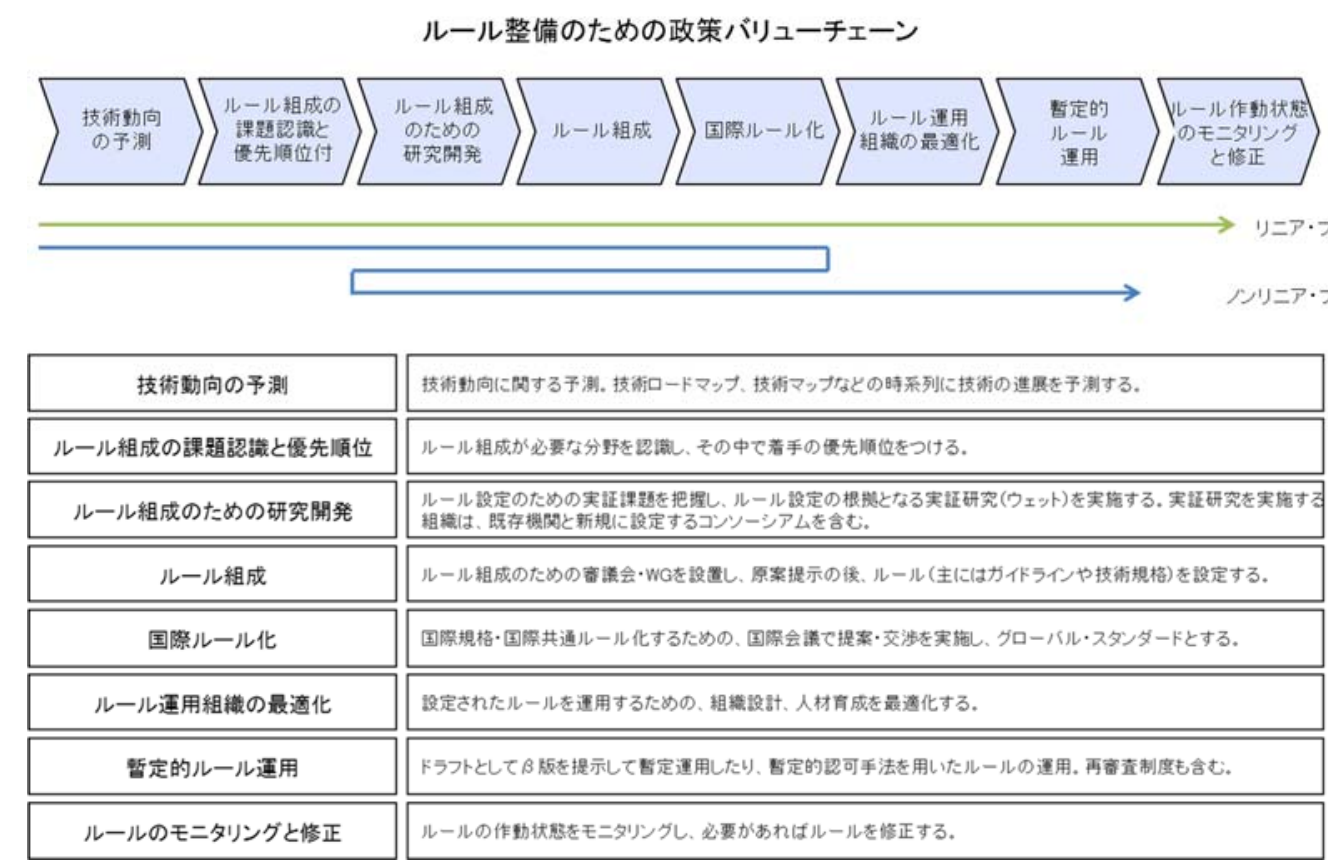

図 5 ルール整備のための政策バリューチェーン

4)イノベーションとレギュレーションの相互作用のプロセス定義

レギュレーション・プロセスとイノベーション・プロセスの相互作用を双方のプロセスを定義 することにより、イノベーターとレギュレーターの相互作用の解析可能とするためのフレームワ ークを設定した(図 6)。

5)レギュレーションのプロセス定義の派生形

ルールの組成プロセスを定義する上で、国際ルールの検討から入る場合を Outside-in，国内ル ールから入る場合をInside-out として区分して用いる(図 7)。ICH や ISO の整備では、先に国際 合意があり、後から国内移行する一方、ローカルなルールのみが存在したり、ローカルルールか ら国際ルールに転換される場合も存在する。 


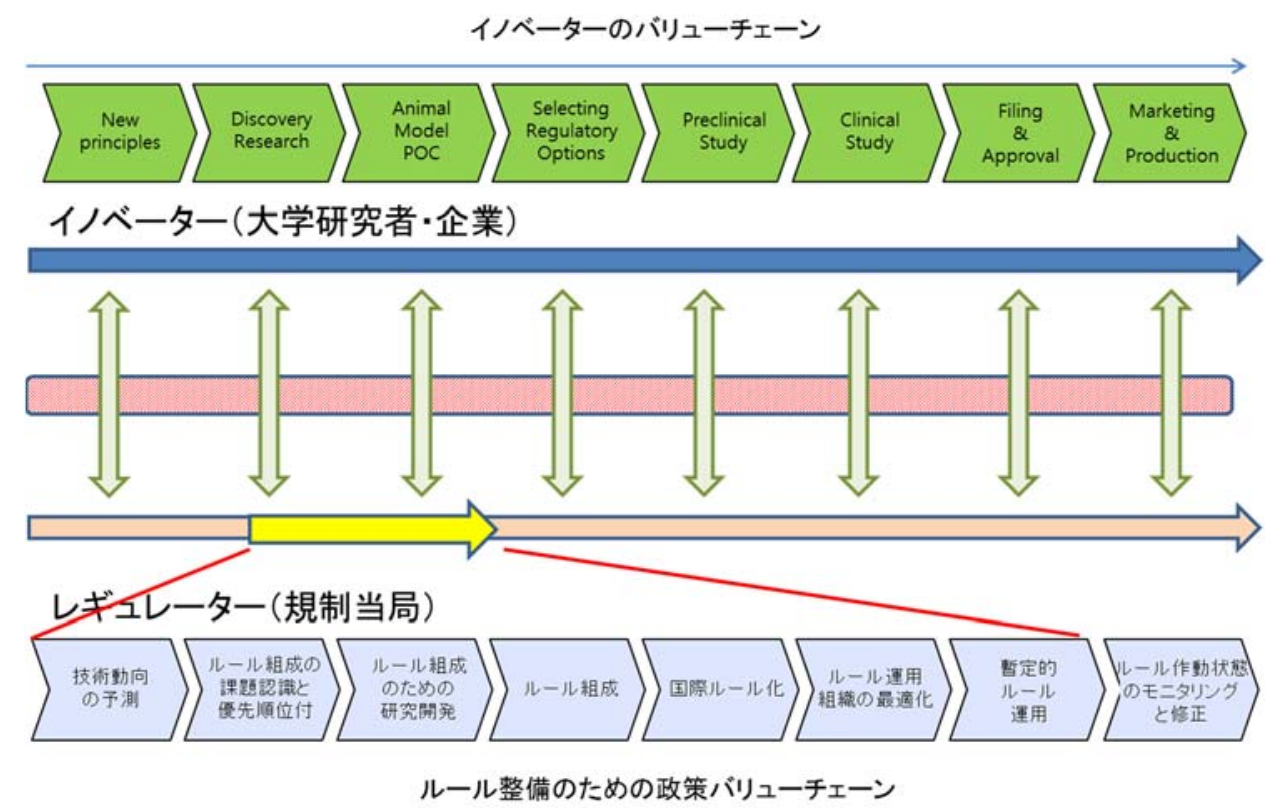

図 6 イノベーター・レギュレーターの相互作用

\section{Inside-outのバリューチェーン(国内規格·JIS)}

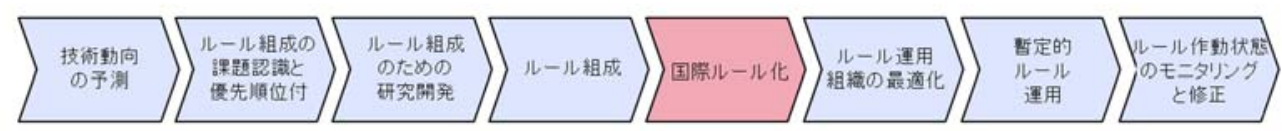

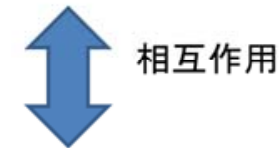

Outside-inのバリューチェーン(国際規格・ICH)

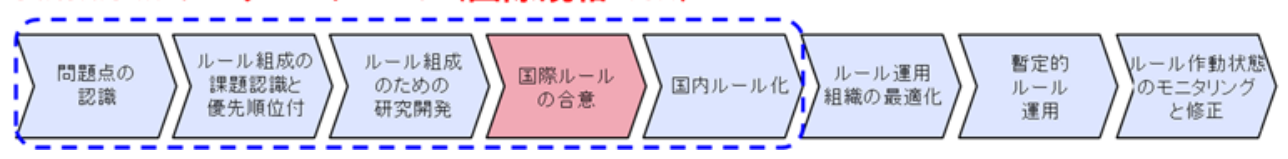

図 7 Inside-out と Outside-in の違い

6) 本研究の regulatory space の定義

イノベーションとレギュレーションの相互作用の状態を時間軸とともに分析していくためには、 技術開発の進展と規制整備のための準備活動の進展の双方を考慮しながら、しかも時系列的に変 動するレギュレーションの対応限界を想定し、分析可能にしておく必要がある。従来の regulatory space の定義では、こうしたダイナミックな状態定義に成功しておらず、したがって、静的な状 態を定義するか、時間軸を無視した概念定義に留まっていたが故に、相互作用の分析に失敗して きた経緯がある。

薬事法によるルールが組成されずに医師法・医療法の制御下で医療の実用化が進展したガンの 細胞免疫療法は、ポジティブリストである薬事法による先端医療技術の制御限界を端的に示して いる。こうした制御限界もしくルールの組成限界は、 $\mathrm{X}$ 軸に技術開発の進展度、 $\mathrm{Y}$ 軸にルール組 成の当局側の能力を置いた際に、技術開発の進展に伴い下に凸に低下していく境界線として表現 できる。この境界線は、当局側のルール組成能力が高ければ早期段階でもルールを組成できるが、 能力が低ければ組成できず、その閾值は技術開発の進展とともに低下していくことを示しており、 
これを「レギュレーション・フロンティア」と本研究では定義する。境界線より上側が On the Rule Space(薬事法によるポジティブリスト的なルールの制御下での活動), 下側が Off the Rule Space (ポジティブリストによるルール制御下になく、医師法によるネガティブリスト的な制御のみが 存在する状態）となる。さらに、「医療での実用化のためにルールが必要となる技術開発の進展度 (On the Rule Point)」を想定すると、この進展度に到達した段階で、必要なルールが組成されて いなければ、レギュレーション・フロンティアとの間にギャップが発生し、このギャップをブリ ッジするためにはルールの組成を待たなければならない状況となる。医療技術の実用化が円滑に 進むためには、On the Rule R\&D（別の表現をとるならば、医療の実用化に必要な規制や技術標 準が裏打ちされて研究開発が計画可能な状態で研究開発が進むこと=On the Rule space 上での 研究開発）の状態に持ち込むことが条件となる（図 8)。

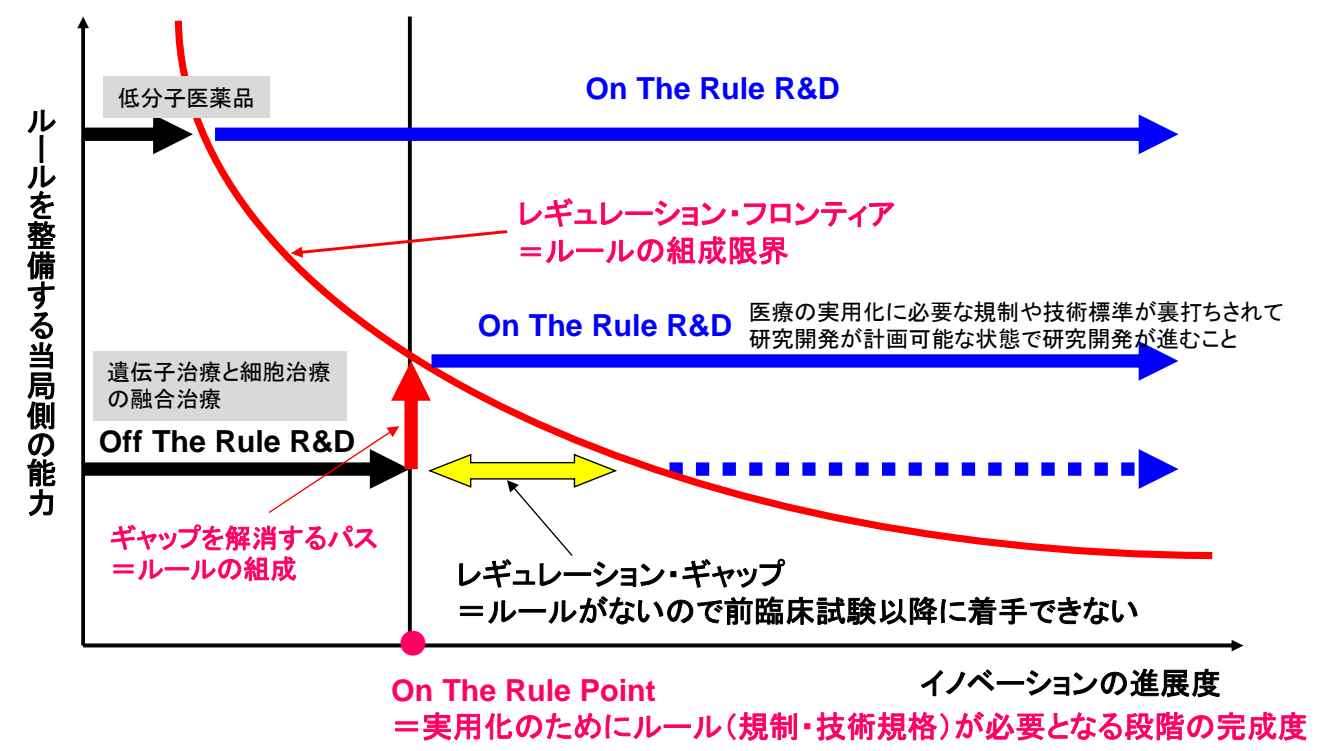

図 8 レギュレーション・フロンティアの概念

レギュレーション・フロンティアの概念上の縦軸は、規制当局の能力要件としているがこれは 政策バリューチェーン上のルール組成の進捗状況としても捉えることができる。したがって、こ の 2 つを組み合わせて、ルールを整備する当局側の能力に政策バリューチェーン上のプロセスを ステップワイズして重ねることで、分析対象としている技術が、技術開発の進捗に応じてどのよ うにルール組成に裏打ちされてきたかを表現することができる（図 6 ）。これを本研究では「レギ ユレーション・パス」と呼ぶ。レギュレーション・フロンティアに対して、レギュレーション・ パスがどのような経路を辿ったかを見ることにより、分析対象技術の進展とルール組成の進捗と の関係を可視化することが可能となる。これを規制当局の対応限界を考慮した、イノベーター・ レギュレーター相互作用の分析フレームワークとして提示し、以降の分析に用いる。

\section{【参考文献】}

[1] Barry, A., 2006. Technical Zones. European Journal of Social Theory, 9(2), 239-253.

[2] Cambrosio, A., Keating, P., Schlich, T., and Weisz, G., 2006. Regulatory objectivity and the generation and management of evidence in medicine. Social science \& medicine, 63, (1), 189_199.

[3] Faulkner, A., 2009. Regulatory policy as innovation: constructing rules of engagement of a technological zone for tissue engineering in the European Union. Research policy, 38 (4), 
637-646.

[4] Hogarth Stuart, 2012. Regulatory experiments and transnational networks: the governance of pharmacogenomics in Europe and the United States, Innovation: The European Journal of Social Science Research, 25:4, 441-460

[5] Markiewicz, K. , Til J. A. van, and Ijzerman, M. J. , "Medical devices early assessment methods: systematic literature review.," Int. J. Technol. Assess. Health Care, vol. 30, no. 2, pp. 137-46, Apr. 2014.

[6] Wilson-Kovacs D., Hauskeller C., 2012. Cardiac stem cell research: regulation and practice in the UK and Germany, Innovation: The European Journal of Social Science Research, 25:4, 409-423

[7] Wild C. and Langer T., "Emerging health technologies: informing and supporting health policy early.," Health Policy, vol. 87, no. 2, pp. 160-71, Aug. 2008

【本研究の成果発表】

$<$ 書籍 $>$

(1) Shingo Kano(東大), "Technology Provider and Receiver Interactions: The Capability

Threshold Concept and Its Application to Technology Assessment,", KIT Scientific Publishing, Karlsruhe, p147-161, 2016

<学会発表 $>$

（1）加納信吾(東大),林裕子(山口大), 中野壮陛(医療機器センター), レギュレーション・フロンティ ア概念に基づく先端医療のルール組成過程の解析, 2013 研究・技術計画学会要旨集 28:755-758、 研究技術計画学会、於政策研究大学院大学、2013 年 11 月

(5) Shingo Kano(東大), How innovation and regulation interact? A new definition of regulatory space and its implication for technology assessment,科学技術イノベーション政策の ための科学 研究開発プログラム 第 3 回国際ワークショップ "TA under Pressure", 於JST市ヶ 谷、July 11 th 2014

（8）加納信吾(東大)，「イノベーションとレギュレーションの相互作用-先端医療のルール組成を 事例として」, 日本 MOT 学会 2014 年度年次研究発表会要旨集, 於東京大学、2015 年 3 月 14 日 (16) Shingo Kano(東大), Interaction Analysis between Innovation and Regulation - The concept of regulatory science as a process (RaaP) and its applications ', 16R0141, PICMET'16 Conference、於ハワイ、2016 年 9 月 6 日

\section{2-2-2. 機能軸: 技術予測とルール組成}

$\mathrm{H} 17$ 年実施の厚生省砂川班アンケート、FDAの医療機器予測レポートの両者の比較、日本に おけるルール組成の実態を分析することにより、技術予測（優先順位付）がルール組成に与える 影響を評価する研究を実施した。砂川班アンケートの技術項目を詳細に分析し、技術予測におけ る技術分類（疾患ニュートラル／疾患特異的）を類型化し、並行して次世代医療機器ガイドライ ンの類型化（プラットフォーム/アプリケーション区分）を行い、技術分類とルール分類の間に は一定のリンク・パターンが存在すること、リンク・パターンには技術の特徴が反映されている ことを明らかにした(文献(6)、(11))。この結果は、特定の新技術が出現した場合に、汎用性が高い 技術の場合にプラットフォーム型のガイドライン作成を行うか、プラットフォームとアプリケー ションの両者のガイドライン作成を行うかについて重要な示唆を与えたと考えている。 


\section{Policy Value Chains for Rule Making in Medicine}

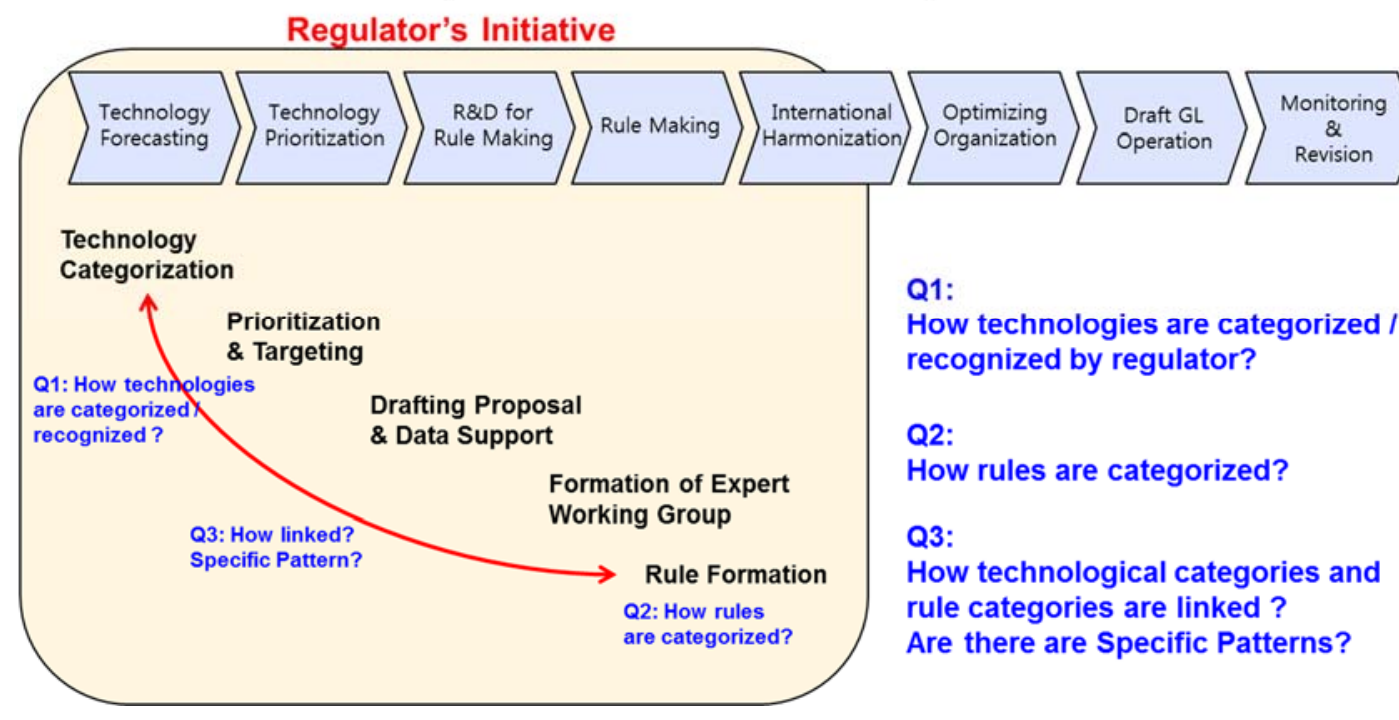

Policy Value Chains for Medical Device Rule Making in Japan

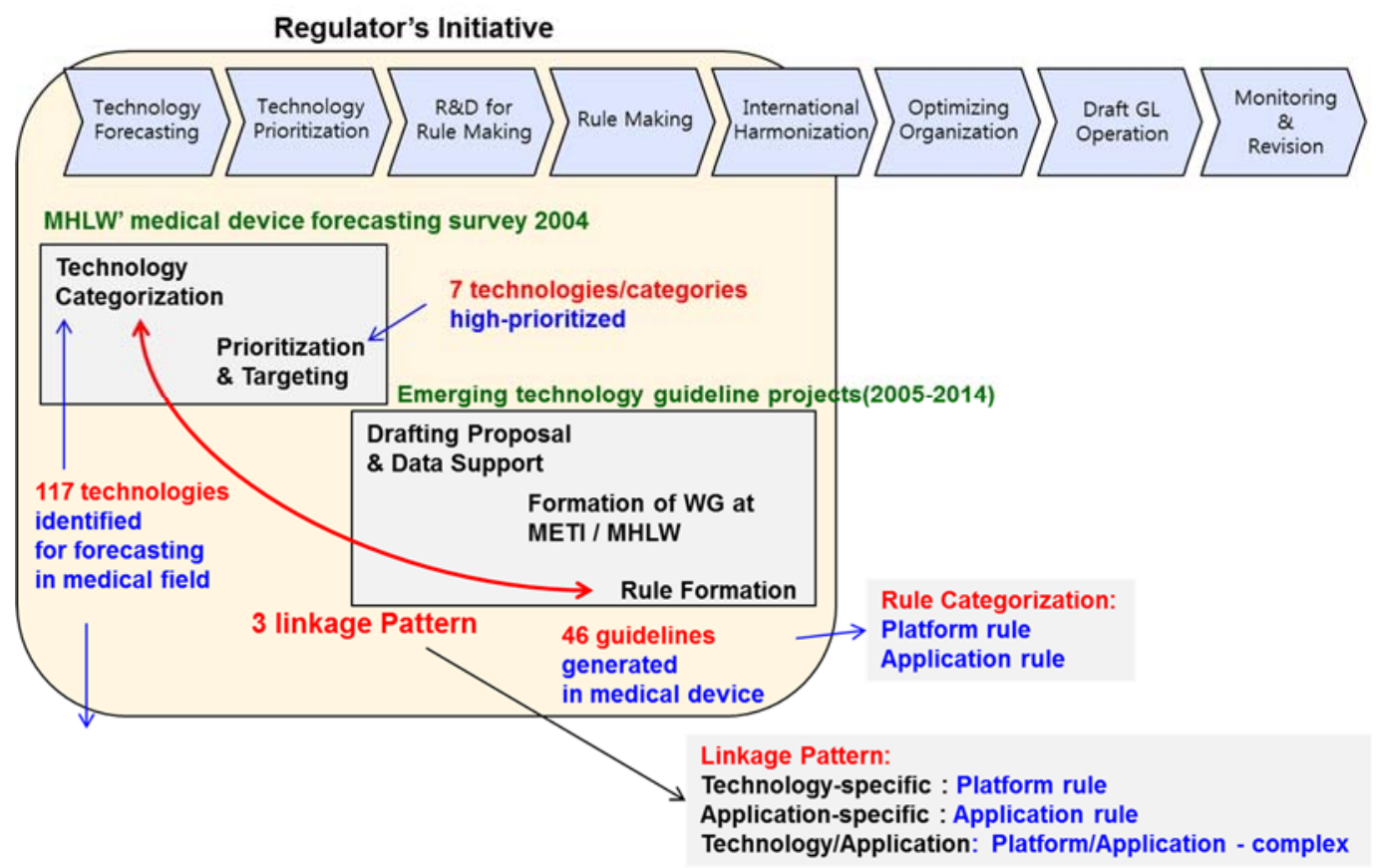

図 9 技術予測からルール組成までの連携の分析事例

\section{【本研究の成果発表】}

$<$ 学会発表 $>$

(6) Shingo Kano(東大), Sayaka Ito(東大), How technology forecasting affects the jurisdiction of technology - A case of Japanese medical device forecasting survey -, Technology Assessment in East Asia: Experiences and New Approaches, 2nd European TA Conference: The Next Horizon of Technology Assessment, Berlin, Germany, February 25, 2015

（11）伊藤紗也佳(東大)，加納信吾(東大)，「技術予測における技術分類概念が医療のルール策定に 与える影響の解析〜次世代医療機器評価指標ガイドラインを事例として〜」，日本 MOT 学会 
2014 年度年次研究発表会要旨集、於東京大学、2015 年 3 月 14 日

\section{2-2-3. 機能軸 : ルールの研究開発}

「ルールの研究開発」の概念を定義するとともに、イノベーターの活動からレギュレーターの 活動が開始される分離過程を検証した。マクロなアプローチとしては、テキストマイニングを用 いて、日本の再生医療のグラントの要旨からレギュレーションがどの程度進展したかを定量計測 した。ミクロなアプローチとしては、米国における人工肺チップ開発の事例分析により、評価技 術が、評価技術のためのガイドラインに適用される過程を分析した。

\section{1)ルールの研究開発の概念}

NIHS 医療機器部主催のコンファレンス「医療機器規格の国際標準化を支援する体制構築に関 する研究」報告会の資料をもとに、医療機器におけるルールの研究開発の特徵とは何かをプロジ エクト参加者全員で議論した。この議論は「レギュラトリー・サイエンスとは何か」という定義 の問題から始まり、イノベーターの活動からレギュレーターの活動がいつどのような形で分離さ れるか、それはどのように観測されるかという問題提起がなされ、このための検証系の開発を本 プロジェクトでは目指し、定量測定、事例分析による定性分析の両面からアプローチした。

ルールの研究開発グループは、本プロジェクト全体に共有する分析軸としての「ルールの研究 開発」は、製品・サービス開発のための研究開発とは異なる、第三の科学であるという認識に立 ってきたが、これを明確にするため、ルールの研究開発を担う機能を「レギュラトリー・リサー チ・エンジン」として定義し、その機能整備や機能強化のための要件についての研究を実施した。

レギュレーターの活動は、イノベーターが開発した原技術とその評価技術に対して、評価技術 を評価し、評価項目を設定して審査技術にバインドさせることにある。従来の科学技術政策の立 案時には、原技術の評価技術への資金投入をもって、レギュラトリー・リサーチへの資金供給を 実施していると解釈しているケースがみられるが、この部分はイノベーターとレギュレーターの 活動がオーバーラップする部分であることには留意する必要がある(図 10)。

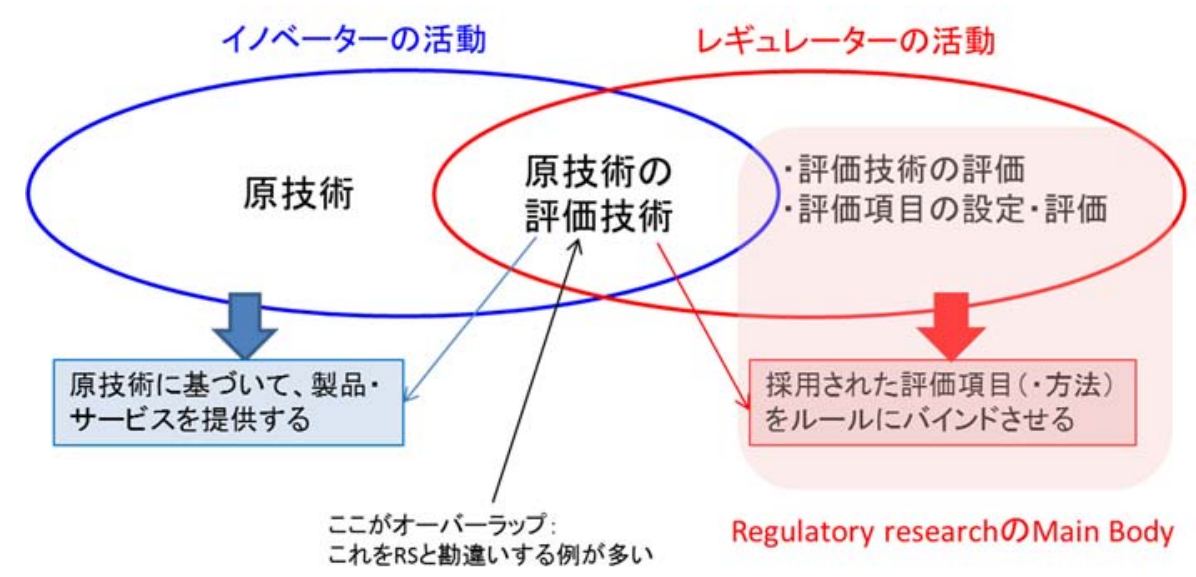

図 10 累積レギュラトリーサイエンス度とガイドライン組成開始の関係

2)レギュラトリーサイエンスの分離に関するマクロ分析

レギュラトリーサイエンスがいつイノベーション活動から分離するのかについてのエビデンス ベースの議論を実施するために、国内の再生医療グラントデータを網羅的に収集し、レギュラト リーサイエンスの発生過程を、テキストマイニングを用いて、特定分野のレギュラトリーサイエ 
ンスの進展度の時系列測定を行い、製品開発の進捗度に関係なく、研究活動の蓄積が一定のレベ ルを超えた段階で、ガイドライン策定活動が始まることを初めて定量的に検証した（図 11）。2 事例のうち、軟骨の事例では、研究蓄積のない中での実用化をガイドライン組成が後追いするの に対して、心筋シートでは、十分な研究蓄積がある場合にはガイドライン策定に十分なエビデン スが揃い、ガイドライン策定後に臨床治験が進むパターンが観察された。いずれもガイドライン 策定のためのワーキンググループが形成されたのは、トータルのレギュラトリーサイエンス度が 総スコアの半分の值をとるときであり、現状日本ではこの 2 例の観測のみ可能であり、一般化に は限定がつくものの、レギュレーターのイニシアティブを議論する上で、これまで測定できてい なかったパラメーターを代理変数ではあるもの測定可能とし、レギュレーションの進展度とレギ ユレーション上のイベントを照合し、レギュレーション関係者が証言する「技術が煮詰まった段 階でガイドラインの整備に着手する」というコメントに合致する結果となった (詳細な方法論は、 (15) 石田瑞(東大), 加納信吾(東大), 「先端医療におけるレギュラトリーサイエンスの発生過程に 関寸る研究」, 2015 研究・技術計画学会要旨集 30: 229-232, 於早稲田大学、2015 年 10 月 11 日 参照)。

軟骨分野における重要度得点(累積)

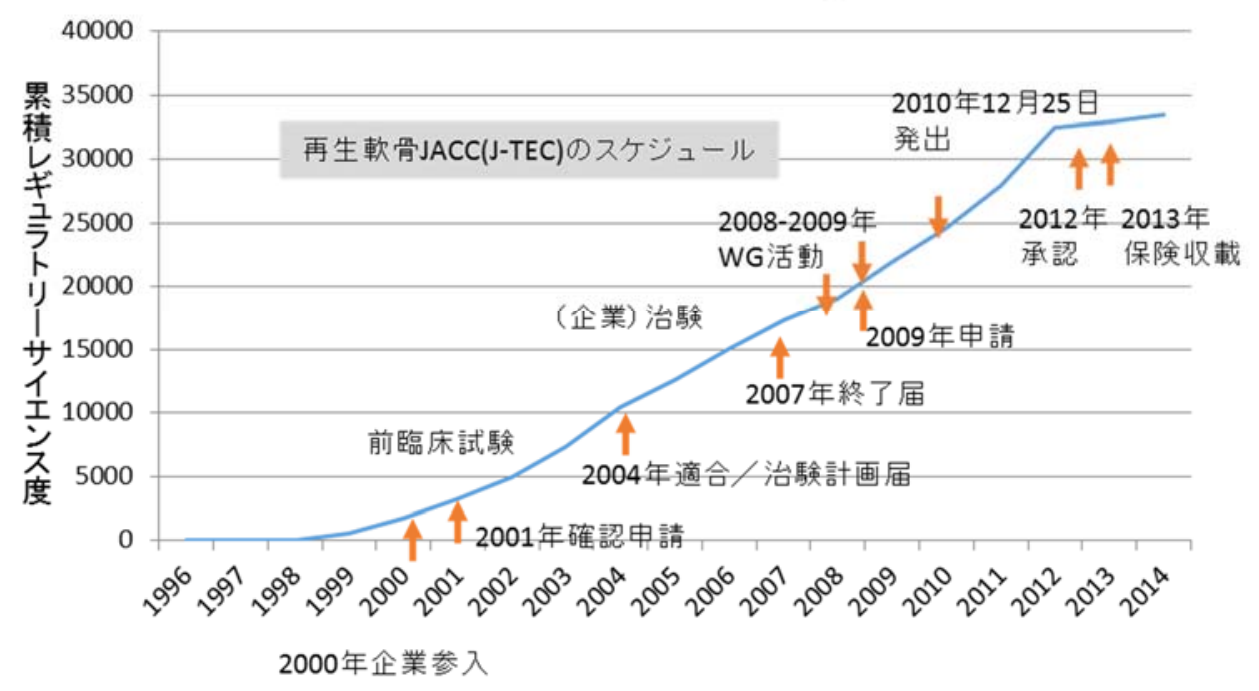

図 11 累積レギュラトリーサイエンス度とガイドライン組成開始の関係

3)レギュラトリーサイエンスの分離に関するミクロ分析

イノベーターの活動からレギュレーターの活動が分離する過程を事例ベースでミクロに観察す るため、NIH と FDA のコラボレーション・プログラムの中から人工肺チップの事例を選択し、 評価技術をガイドラインに載せるためのガイドライン (Guidance on Qualification Process for Drug Development Tools: DDT) [1]に向けて、イノベーターの活動をレギュレーターが誘導する 過程（ガイドライン・ターゲティング）を分析した。

人工肺チップは、The DARPA-FDA-NIH Microphysiological Systems Program として 2011 年にスタートし、人体の各器官を模擬的に体外で再現する微小な生理学的システム(in vitro microphysiological systems representative of major organs/tissues) として、候補医薬品に対す るバイオマーカー、血中濃度、有効性、安全性を臨床試験の前段階で評価するためのデバイス作 成を目的とし、肺、心臓、腎臓、筋肉、皮膚、脳、睪丸、骨䯣、肝臓の人工チップ製作を目指い して、最初のアプリケーションとして、the Heart-Lung Micromachine for Safety and Efficacy Testing project(肺と心藏の人工チップ)がハーバード大学の Wyss Instituteにて開発が進められ ている(図 12)[2]。 

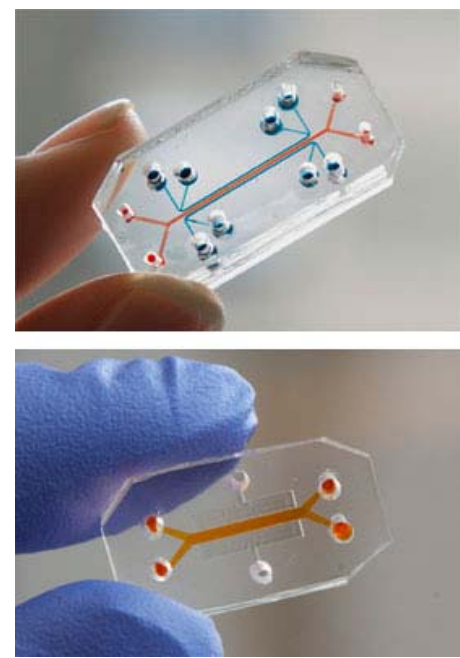

図 12 人工肺チップ
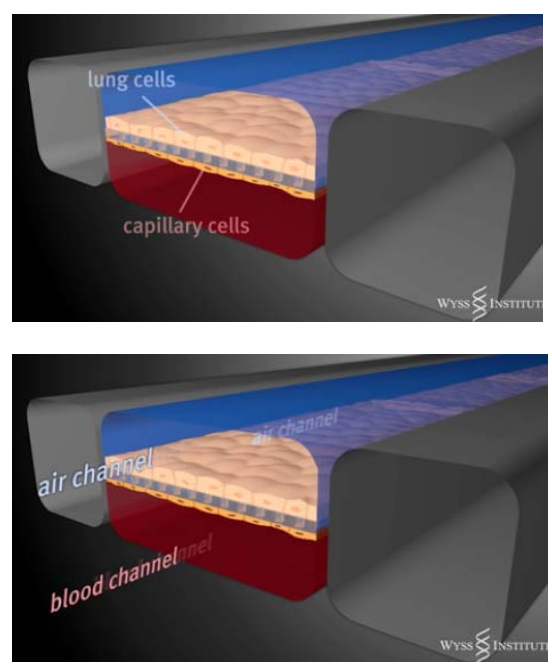

(Wyss Institute HP より)

DDT はルール・オブ・ルールに該当するガイドラインであり、特定の技術に非依存的な汎用ガ イドラインとするため、Context of use(技術が利用される文脈：COU)を一般的に定義し、COU における当該利用技術の妥当性を検証してオーソライズする(Qualification=評価技術の評価と 妥当性の証明)プロセスを明示し、その技術の使用方法を正規のガイドラインとして認定するまで のプロセスを詳細に定義している。特定領域の製品ではなく、製品の評価技術を GL に載せるた めの汎技術的 GL は、米国の「ガイドラインのためのガイドライン」である Good Guideline Practice とプロセス定義上は内容的にオーバーラップしつつも、入口部分のプロセスを評価技術 のために詳細に定義し、詳細なフローチャートをガイドラインの中で示して、新規に出現してき た評価技術が円滑に医療技術の評価に利用される仕組みを評価技術の保有者に開示している。

人工肺チップにこの DDT ガイドラインに適用されるように、FDA は研究段階から Context of use を定義し、FDA が要求するデータの項目についてのアドバイスをハーバード大学に対して行 っている[3]。

人工肺チップの事例は、イノベーターの活動からレギュレーターの活動が分離していく過程を 端的に表しており、イノベーターをレギュレーターがガイドしていきながら、同時にガイドライ ンを組成していく例として興味深い。日本でも同様の試みとして、革新的医薬品・医療機器・再 生医療製品実用化促進事業が実施されているが、これらは「加工細胞の品質評価法(平成 24 年 タート)」を除いて、全て製品に関寸るものであり、評価技術に関寸る汎用性の高いガイドライン からスタートするアプローチとは異なり、プロセスを一般定義していない。

日本には、評価技術に対する汎用的なガイドラインは存在せず、今後はこの種のガイドライン を整備することにより、再生医療や安全性薬理分野での評価技術を進展させることができるもの と想定された。医療機器分野でも同様の評価記述のためのガイドラインMDDT(Medical device development tool)があり、性能評価技術を審査に使えるように促す仕組みを FDA は用意してお り、これは先端医療機器 $\mathrm{G}$ にて事例分析している。 


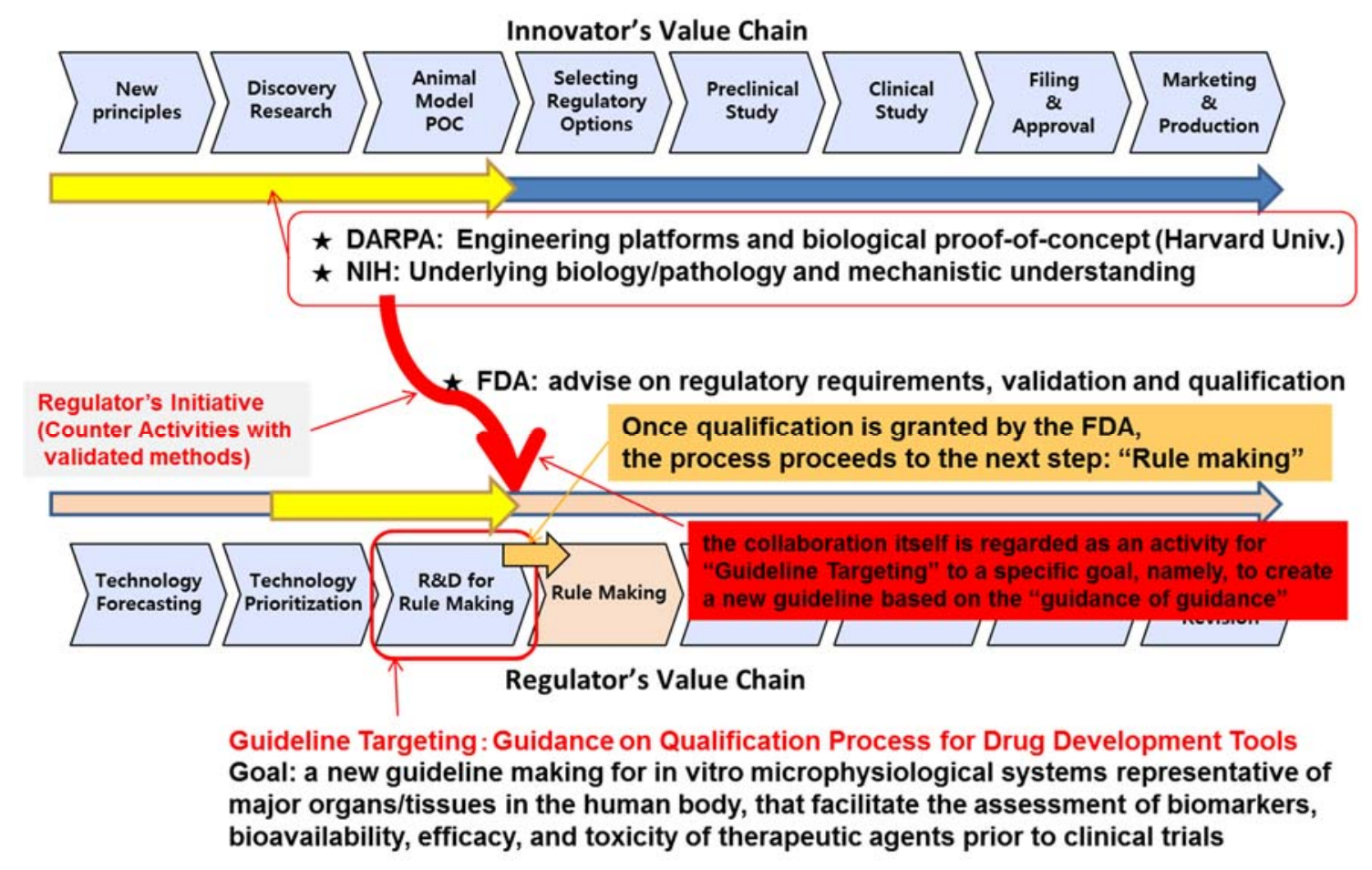

図 13 ガイドライン・ターゲティングと DDT

\section{【参考文献】}

[1] FDA homepage: FDA-NIH Joint Leadership Council Charter

Available: http://www.fda.gov/scienceresearch/specialtopics/regulatoryscience/ucm201654.htm(2016/11/10)

[2] FDA Draft Guidance on Qualification of Drug Development Tools: Available:

http://www.fda.gov/downloads/Drugs/GuidanceComplianceRegulatoryInformation/Guidances/ UCM230597.pdf

[3] Suzanne Fitzpatrick, PhD, DABT, US FDA, "FDA/NIH/DARPA Microphysiological Systems Program and Qualification of Drug Development tools,"

【本研究の成果発表】

<論文>

P-(4) Shingo Kano (2016), Interaction Analysis between Innovation and Regulation - The concept of regulatory science as a process (RaaP) and its applications -, ID: 16R0141, PICMET'16 Conference Paper

<学会発表 $>$

（15）石田瑞(東大)，加納信吾(東大)，「先端医療におけるレギュラトリーサイエンスの発生過程に 関する研究」, 2015 研究・技術計画学会要旨集 30: 229-232, 於早稲田大学、2015 年 10 月 11 日 (16) Shingo Kano(東大), Interaction Analysis between Innovation and Regulation - The concept of regulatory science as a process (RaaP) and its applications -, 16R0141, PICMET'16 Conference、於ハワイ、2016 年 9 月 6 日

(18) 加納信吾(東大), 先端医療の薬事規制におけるルール・オブ・ルールに関する研究，第 31 回 研究・イノベーション学会年次学術大会 $2 \mathrm{I} 03$, 於青山学院大学、2016 年 11 月 6 日 


\section{2-2-4. 国際ルール化}

1)エビデンスからの理想モデルの構築

国際ルール化の過去事例としては、各セクターグループで取り扱っている事例の中から、特に 国際ルールとして成立した事例を選択して解析した。再生医療ツールから ICHS7B/E14, 個別化 医療デバイスから ISO/TC 34 ISO16578 を事例選択し、薬事ガイドラインや技術標準形成におけ るイニシアティブ発揮の要件をモデル化して記述した（図 14)。過去のシナリオについてはセク ター軸で実施した。

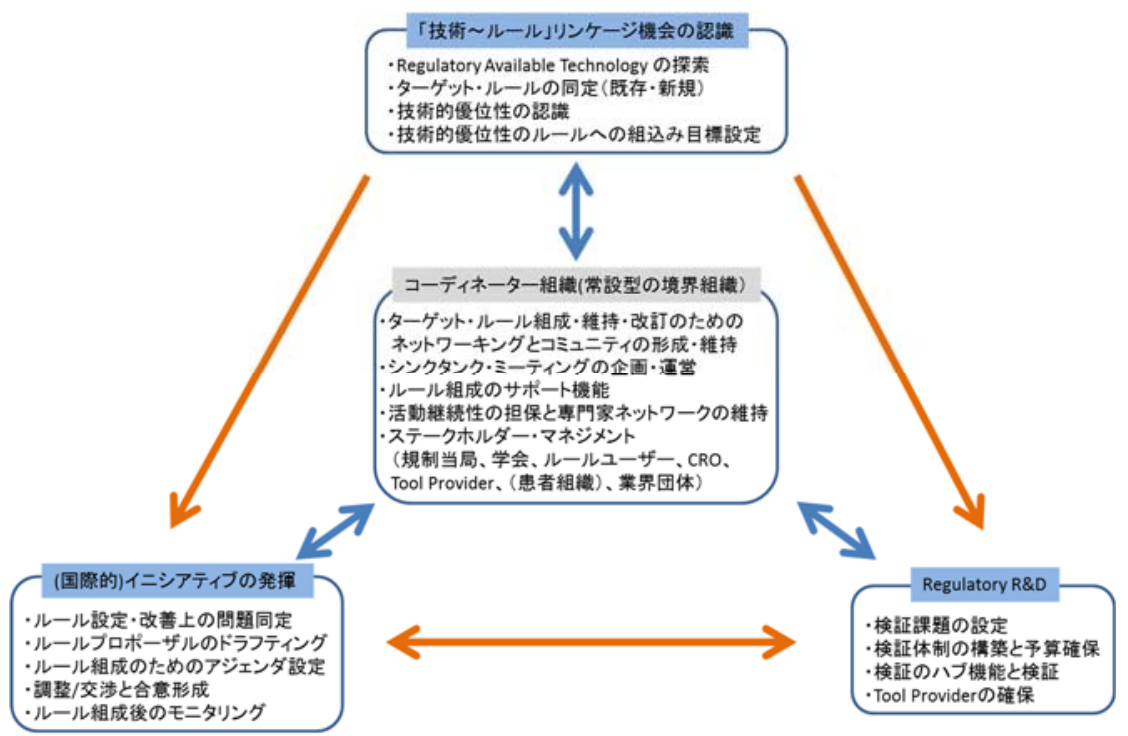

図 14 新規（評価・計測）技術をルール組成へ展開する構図（理想モデル）

2)国際ルール化における選択肢の検討

ルールの研究開発は、国際的なルール組成のイニシアティブ競争に関連しており、レギュラト リー・リサーチ・エンジンを機能していることを前提とした場合に、日本のポジショニングとし ての選択肢の分岐を整理した（文献(14)）。先端医療におけるルール組成とその運用においてグロ 一バルなイニシアティブを発揮するためのいくつかの要因を想定し、その組み合わせがもたらす 複数の状況を仮想的に設定して比較することにより、日本の Regulatory Initiative における目標 設定の妥当性は何によって検証されるかという論点を割り出すことを目的とした。

まず、企業が開発国を選択する基準として、先端医療技術の実用化を目指す企業が事業計画を 立案する際に、最初に検討すべき点としては以下の 3 点が挙げられる。(1)対価設定 : いくらで製 品が売れるかの予測性が低ければ製品開発に着手できない、(2)開発環境 : 臨床開発するためのル 一ルがあるか、どれくらいの審査期間を要するか。その負荷はどれくらいか、(3)開発成果の普遍 性 : A 国での臨床データを B 国でも使って申請ができるか、開発のやり直しとなるか、これらの 要件が想定製品に対して一定の精度で予測できなければ開発できないし、より予測可能性の高い 国、高い対価設定が期待できる国で開発するのが合理的な企業行動となる。医薬品ではまず米国 で臨床開発が実施され、医療機器ではまず欧州で臨床開発されるのは、先端医療製品の開発をこ れらの条件が良い国でスタートさせているためである。企業が初発品の臨床実施国を選択してい る要因は、各国の規制当局の戦略の裏返しであり、より先端医療製品が普及するためのルール組 成と運用を実施するに際して国際協調においてに対してリードしていくことを「Regulatory

Initiative」として本研究では定義した。日本は先端医療における規制の整備と運用をどのような レベルで実現することを政策目標として設定すべきかを検討するため、その論点となり得る要因 として、Regulatory Position, Regulatory Umbrella, Incentive System の 3 つの優先パラメータ 一を列挙し、それぞれのパラメーターがとり得るレベルとその組合せにより実現する複数の世界 
像を提示した。特にレギュラトリー・ポジションの 4 分類（図 15）は、日本のゴールセッティン グが、レギュラトリー・リサーチ・エンジンとの関連で整理されることを示した。

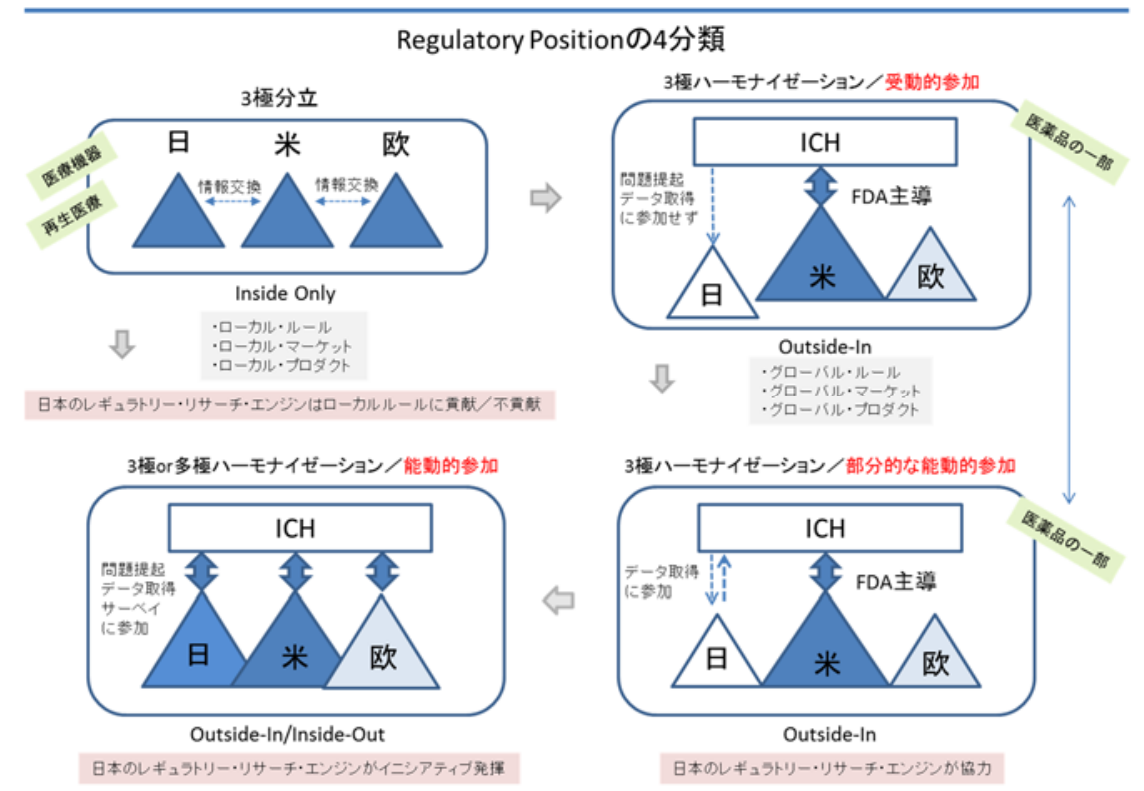

図 15 レギュラトリー・ポジションの 4 分類

また、医療機器、再生医療では日米欧が全く異なるレギュレーション体系を維持していることか ら、ルール組成において国際イニシアティブを発揮することが難しく、2つのアプローチから調 查を実施した。

第一のアプローチは、再生医療におけるルール組成はどのようにしてハーモナイゼーションに 至るのかを検討するために、同一製品に対する日米欧のガイドラインの内容を比較する視点であ る。このため、培養軟骨を事例として、日米欧のガイドラインの詳細を比較し（文献(10))、更に ハーモナイゼーションの方向性に関する検討を実施した（文献 P-(2)）。日本で最も多いガイドライ ンは，狭い製品区分に対して包括的な情報を要求する、体性幹細胞（自己/同種），iPS 細胞（自己 /同種), $\mathrm{ES}$ 細胞を対象とするいわゆる「5 指針」があり、「次世代医療機器の評価指標」も日本の このスタイルに大きく影響していた。一方、欧州は日本とは対照的に，幅広い製品区分に対して、 事務手続き、品質及び治験などの特定の情報区分に特化したパターンのガイドラインが最も多い。 細胞治療・医療機器・遺伝子治療を包括的に規制する ATMP の概念が影響している。こうした差 異から、ハーモナイゼーションへの道のりは遠いことが推測され、中長期的にも地域毎の対応が 必要となる。

第二のアプローチは、医療機器分野におけるハーモナイゼーション活動の実態調査である1。日 米の当局（FDA-PMDA）において実施されている、「Harmonization by Doing（HBD）」は、心 臟分野における日米当局者の交流活動であるが、日米双方の担当官にヒヤリングした結果、これ までほとんどコミュニケーションされてこなかったものの、双方が考え方を共有することにより、 考え方には相違がなかったことが判明したこと、また HBD 活動は依然として分野限定的であり、 八ーモナイゼーションが体系的に進展する可能性は現状想定されていないことが判明した。しか

1岩元 真, 方 眞美, 鈴木 由香, 医療機器審査の迅速化に向けた米国 FDA との Collaborative

Scheme 及び Harmonization By Doing (HBD) 活動，レギュラトリーサイエンス学会誌、Vol.

5 (2015) No. 3 p. 227-234 
しながら、差異がないとの当局同士の感触は最も差異がない製品領域に限定的な見解であるのか、 否かについては追加検証を要する。

3) ISO におけるマネジメントのモデル化と未来への適用

国際ルール化は Outside-in 型のルール組成であり、医薬における ICH 形成のマネジメント、 医療における ISO 形成のマネジメントは、プロセス定義は異なるものの、プロセスが定義されて いるという点で明示的なマネジメントがなされるという点で共通している。当グループでは、

ISO16578 を事例として、「Before, On Process, After」の 3 段階モデルを構築し、技術の目的的 概念化と ISO の体系化が競争優位をもたらすことを説明した(ISO イニシアティブモデル)(図 16)。 このモデルは一般化可能であり、特に On process のマネジメントだけでなく、Before 段階と After 段階の重要性を一般定義したモデルの汎用性は高く、個別の ISO 策定におけるシナリオプランニ ングへの適用可能性は高いと判断された。ただし、モデルにおける 9 つのファクターは全て必要 条件であり、分岐は失敗脱落としてシナリオ上は記載されるため、五月雨式のシナリオツリーに なることから、シナリオ分岐を記載する必要性は低いと判断された。

未来事例としては、ISO/TC276（バイオテクノロジー）を想定した。個別の国際技術標準整備 に必要なこれを未来シナリオにも適用し、「日本の独自性を国際ルールに組み込もうとするか否か

(国際的なポジションの追求の程度)」、「イニシアティブが発揮されるか否か (イニシアティブ不 全症候群)」で決定されうるとして、将来シナリオについて検討した。「Japan コミットメント」、 「絵に描いた餅」「「ガラパゴス」の3つのシナリオが想起された(図 17)。

全体シナリオとしては、「境界組織の常設化」「メンタルモデルの改善」、「技術標準ポートフォ リオの構築」等のサブのシナリオ分岐として想定することができ、これらによっても未来は分岐 することが議論された。

ISO Initiative Model

\begin{tabular}{|c|c|c|}
\hline Before Rule & Rule Making & After Rule \\
\hline $\begin{array}{l}\text { Rule Target Validation } \\
\text { For Innovation }\end{array}$ & Innovation to Standard & Standard to Re-innovation \\
\hline $\begin{array}{l}\text { Target Technology } \\
\text { Identification } \\
\text { (対象技術や想定製品 } \\
\text { の同定) }\end{array}$ & $\begin{array}{l}\text { Agenda Creativities } \\
\text { (課題設定能力) }\end{array}$ & $\begin{array}{l}\text { Implementation } \\
\text { (5か国以上実施、認証機関の } \\
\text { 設置) }\end{array}$ \\
\hline $\begin{array}{l}\text { Market Identification } \\
\text { (対象市場の同定) }\end{array}$ & $\begin{array}{l}\text { Supporting Data } \\
\text { (規格の根拠となるデータ } \\
\text { の取得) }\end{array}$ & $\begin{array}{l}\text { Facilitate Modular } \\
\text { Innovation(re-innovation) } \\
\text { (規格を活用した研究開発) }\end{array}$ \\
\hline $\begin{array}{l}\text { Domestic Kick-off } \\
\text { (国内委員会での合意) }\end{array}$ & $\begin{array}{l}\text { Consensus Building } \\
\text { (コンセンサス形成) }\end{array}$ & $\begin{array}{l}\text { Linking Standards } \\
\text { (モノとモノの標準、モノとサービス } \\
\text { の標準をリンクさせる) }\end{array}$ \\
\hline
\end{tabular}

図 16 ISO イニシアティブモデル 


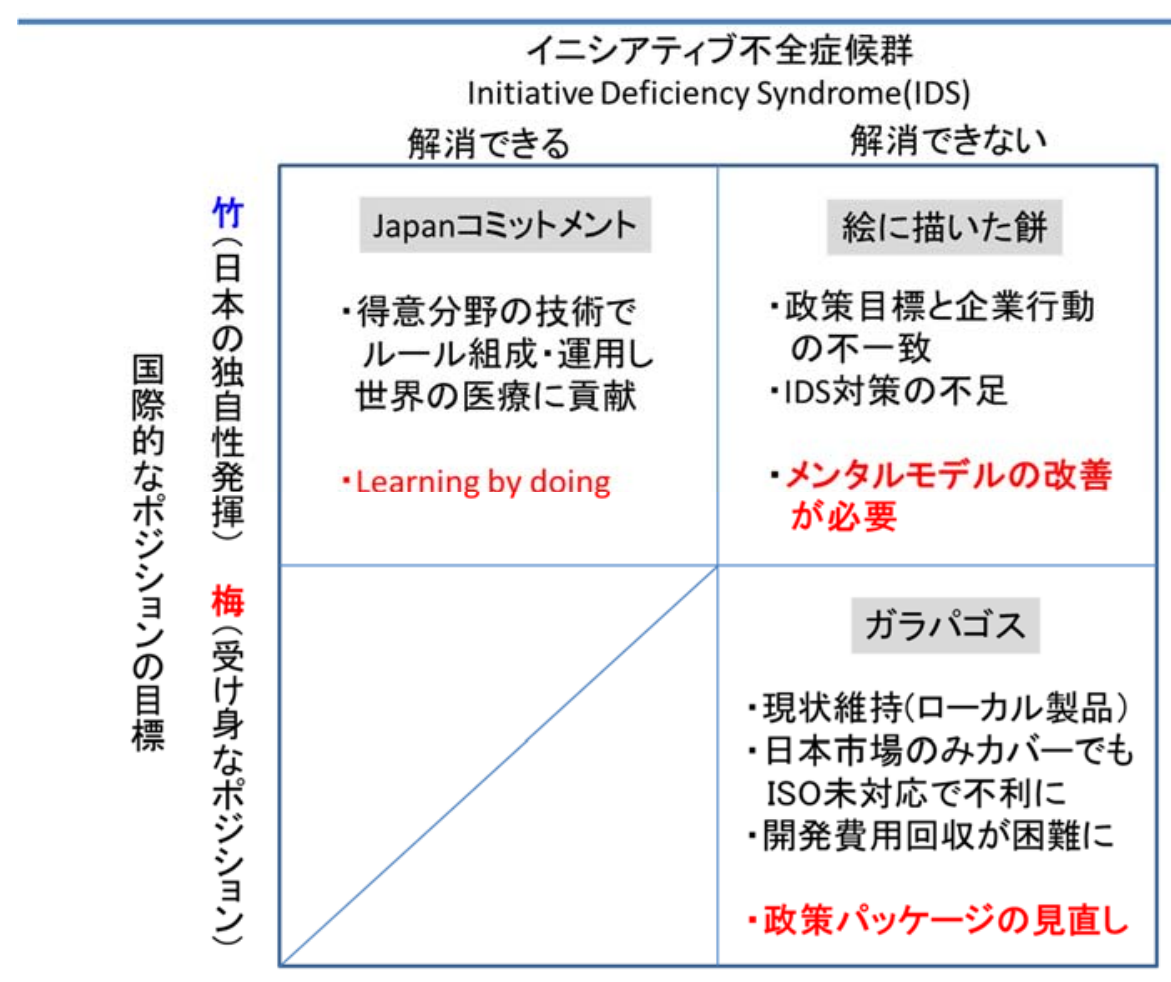

図 17 ISO 策定における将来シナリオ

\section{2-2-5. 機能軸 : 境界組織}

1)ルール組成を担う組織体

技術開発の進展に対して、規制当局側がルール組成に着手寸る場合、それが他国で既にルール 化されているものでなければ世界で初めてルール化に取り組むことを意味しており、薬事規制に おけるガイドラインであれ、技術標準や技術規格の整備であれ、規制当局側による新技術の制御 のための活動は参照文献がない中で開始される。この段階から「regulator と innovator が相互作 用寸る場」が形成されていくことになるが、どのような場がどのようなメンバーで設定され、そ の場ではどのように活動が行われているか、何が誰によって課題設定され、何を情報ソースとし て、何が検証され、何が結論されているかが分析されなければ、「co-development of a regulatory arena and novel technology」への転換を議論するべースはできあがらない。ルール組成の初期過 程を担う組織体はどのような組織と機能を持つべきかについては、初期フェーズにおけるイノベ ーターとレギュレーターの情報交換に着目する。

(境界組織分析におけるバリューチェーンのフェーズ分け)

ルール組成の政策バリューチェーンに沿って、Before（前工程） $\rightarrow$ On Process（ルール化） $\rightarrow$ After (後工程) $\rightarrow$ Before 2 (次のプロセスの前工程) のフェーズ別に境界組織の機能を、(1)境界 組織の管理スキームの設立・維持機能及び関係者を集めるネットワークキング機能、(2)技術〜ル ールのリンケージ機会の認識、(3)アジェンダ設定機能、(4)レギュラトリー・リサーチのための資 源確保機能の 4 つの要素機能により分析するフレームを設定した(図 18)。このフレームワークで、 ルール組成の政策バリューチェーンのフェーズに応じて、どのような境界組織がどのような媒介 機能を担っているかをマッピングすることができ、ルール組成過程におけるステークホルダー(メ インはイノベーターとレギュレーター）の体系的な整理が可能となった。この政策バリューチェ ーンを用いたルール組成過程の国際比較や、個々の技術に関する比較をすることにより、どのフ 
ェーズが抜け落ちているため、ルール組成が滞っているかといったバリューチェーン上の機能不 全や「ルールの研究開発」と「国際ルール化」の連動状態を分析することが可能となる。

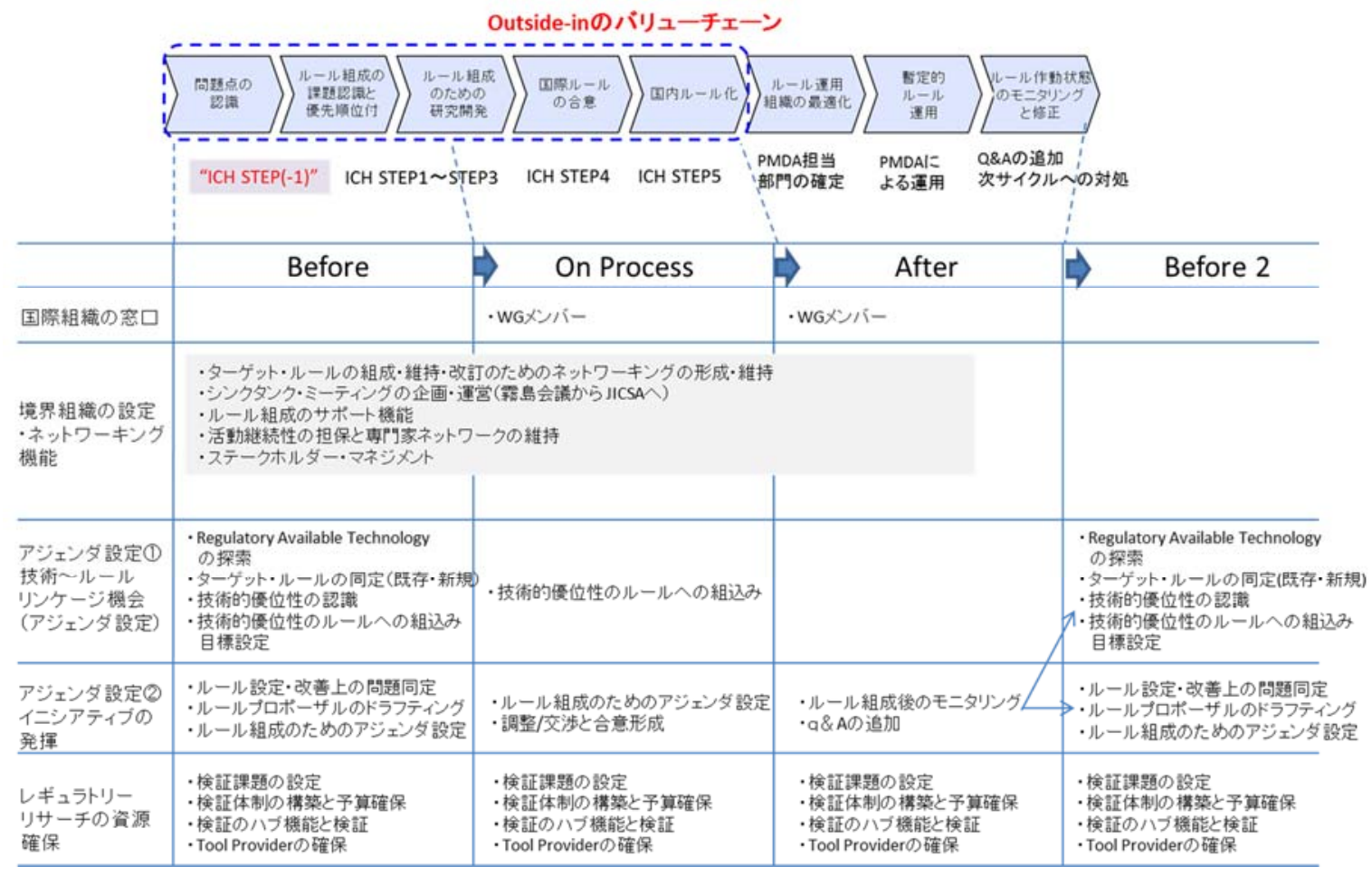

図 18 境界組織分析のための分析フレームワーク

（境界組織の分類とその特徵）

本来的に、規制当局に対しては、先端医療技術に関する情報の非対称性（技術知識の不足）が 存在しており、一方で開発企業や大学研究者に対しては政策決定に関する情報の非対称性（政策 知識の不足）が存在することから[1],[2]、この双方向の情報の非対称性を緩和する場として、従 来型の境界組織（審議会やガイドライン WG 等）だけでなく、業界団体や規制当局側の研究組織 の活動も含めた「広義の境界組織」の分類と機能を分析していくことが求められる。

境界組織の主要な機能を果たすための組織設計には多様な組み合わせが考えられる。レギュレ ーター主導、イノベーター主導、中立、また、一つの分野の製品を扱うシングルタスク型、複数 の分野の製品を扱うマルチタスク型、等のバリエーションがありえる。既存の業界団体や中立組 織の組織（例えば、医療機器センター）がルール組成における境界組織として機能する場合から、 新しい技術で業界が形成される以前のもの(バイオチップコンソーシアム)、再生医療のように新産 業の場合には新たにルール組成のための境界組織が業界団体としても機能し得る場合（再生医療 イノベーションフォーラムなど）もあり、文献(2)にその分類概念を提案した。技術・産業の特性 に応じて、その国の社会システム・業界慣行に配慮した組織設計やインセンティブの設定が想定 されるが、シングルタスク型とマルチタスク型では機能的には共通部分も多いため、HESI や医 療機器センターのような複数のテーマを扱う境界組織のほうが、継続性を考慮したときに有利で ある点は指摘しておきたい。

(分析対象とした事例)

各セクター・グループからリストアップされた境界組織の事例は、ルール組成において境界組 織が例外なく必須であることを示しており、境界組織分析を主要な分析フレームワークとして設 定したことが妥当であったとの確信を持つに至っている。境界組織を分析するための一般的なフ レームワークを提示し、各セクターにおける重要な境界組織に対して以下の事例分析を実施した 
(詳細な事例分析の結果の一部は、セクター軸側でも報告)。再生医療・治療(再生医療安全確保 法の WG・次世代医療機器ガイドライン培養軟骨の両 WG)、再生医療・ツール(ICHS7B 整備に おける QT-PRODUCT、米国 ILSI/HESI、安全性薬理研究会、ICHS7B-EWG)、個別化医療・ツ ール(次世代医療機器ガイドライン DNA チップの両 WG、米国 MACQ プロジェクト、JMAC、

ISO16578 を担当した ISO TC34)、個別化医療・創薬(ヒューマンサイエンス振興財団規制動向調 查 WG)、先端医療機器(次世代医療機器ガイドラインにおける両 WG 全般)などを分析対象とした。

(事例解析の示唆)

マイクロアレイ、ICH S7B/E14における事例解析では、活動していた境界組織を同定し（図 19)、の結果から、境界組織の分析フレームワークに基づいて、イノベーター、レギュレーターと 境界組織の機能を分析し(図 20、21)、以下のことが明らかになった。
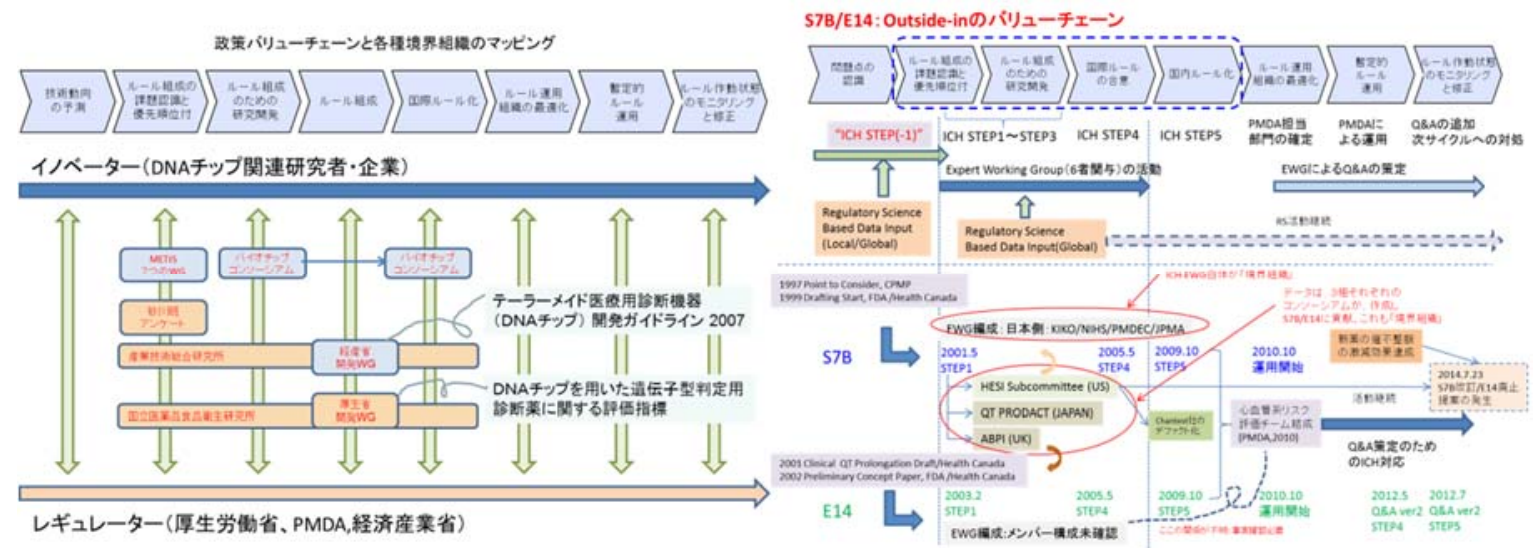

図 19 日本の DNA チップにおける境界組織と ICHS7B における日米欧の境界組織

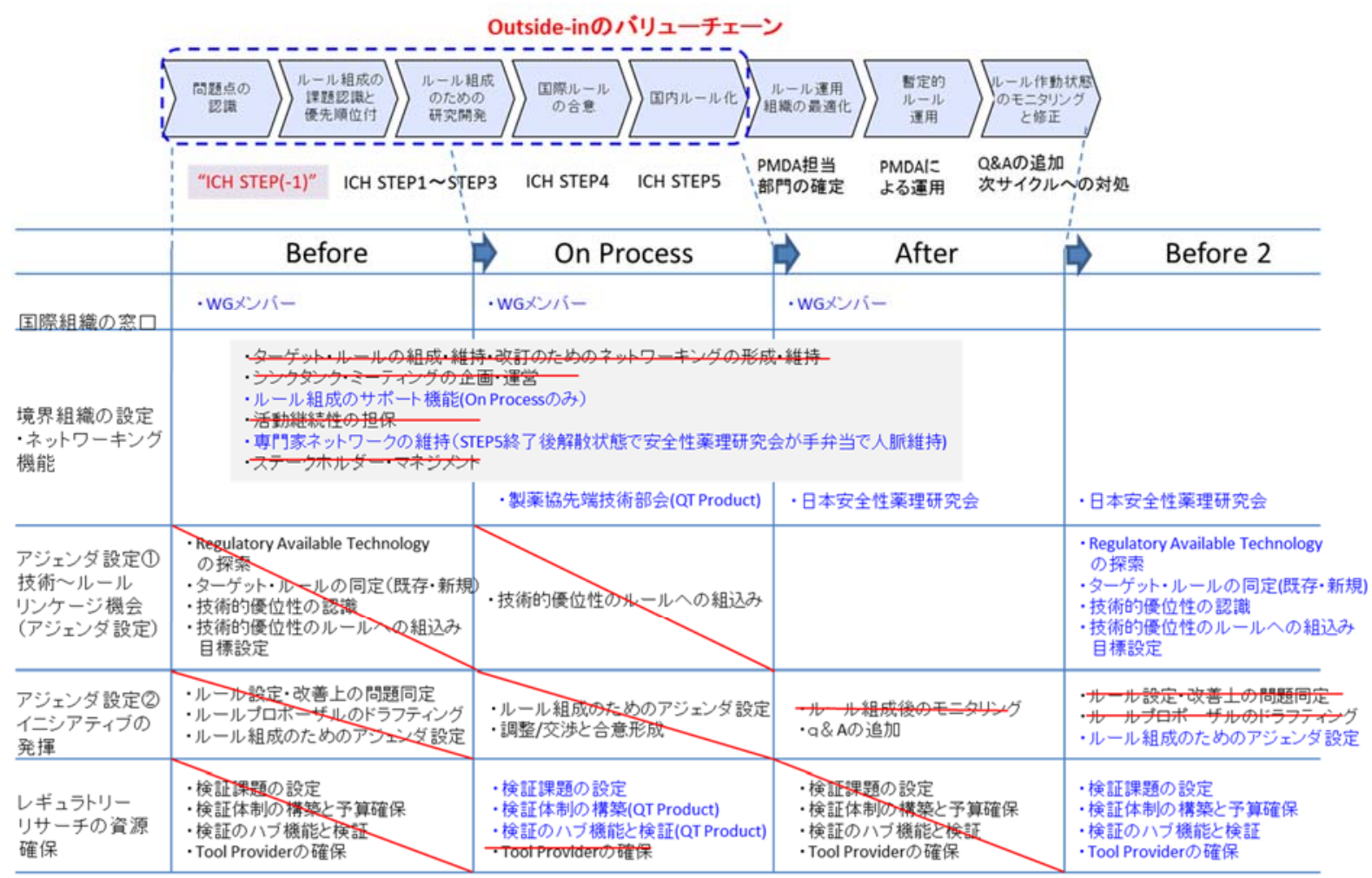

※青字は日本側で成立したもの

図 20 ICHS7B における日本の境界組織(1997-2010) 


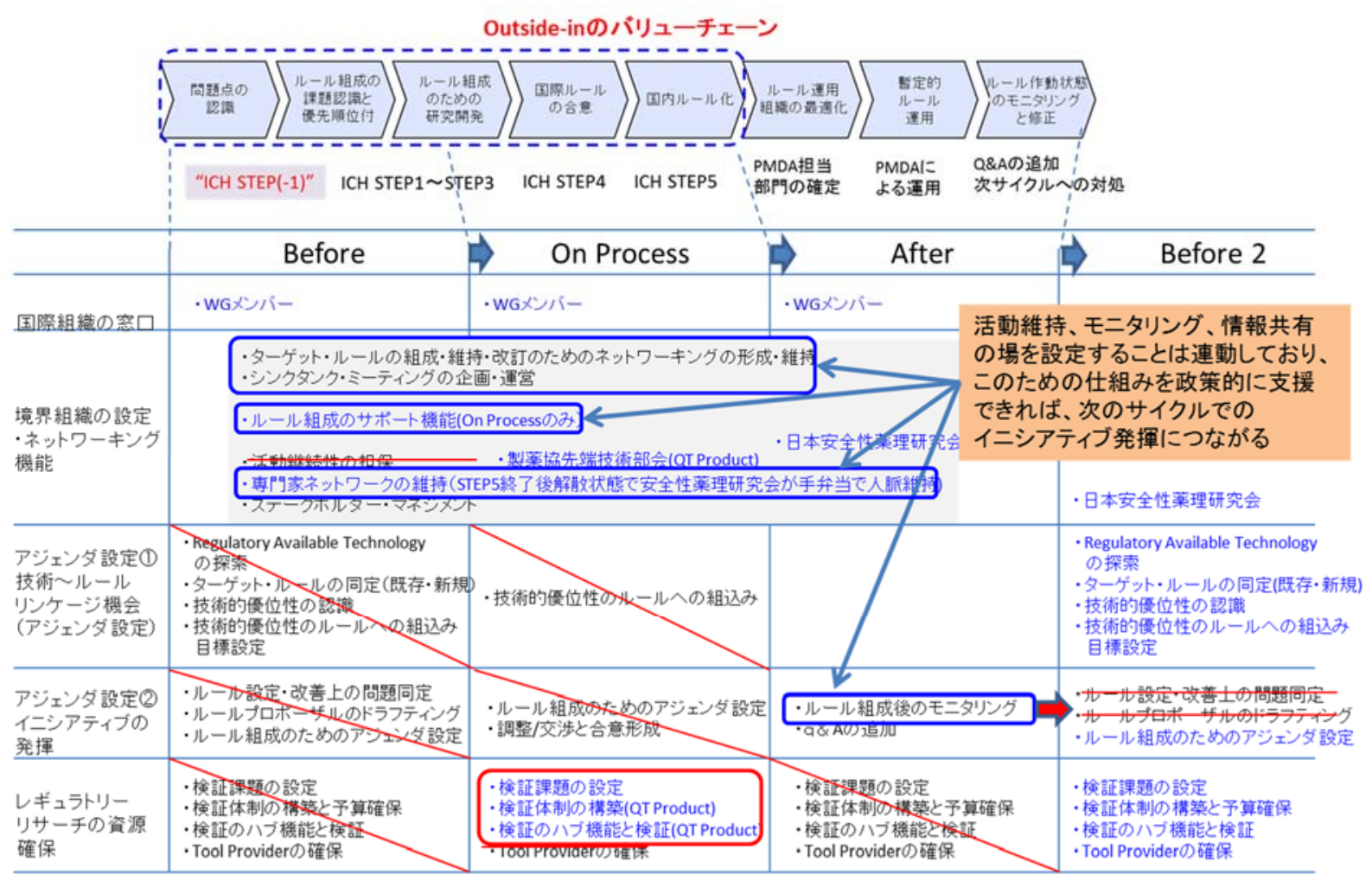

※青字は日本側で成立したもの

図 21 ICHS7B における日本の境界組織(1997-2010)の改善点（青枠部分）

・境界組織の継続性 : あるイノベーターに特定の新技術(デファクト化している技術)に対して は、イノベーター（例えば企業）が直接規制当局とやり取りを行うため、境界組織は必要で はない。しかし、いくつかのイノベーターに共通する新技術、新分野ではコンソーシアムや ワーキンググループのような形で境界組織形成される。米国側に存在する HESI のように、

ICH-EWG の下部組織的となる継続的な境界組織が Before/After 段階においてルールの組成 と改訂における国際的な主導権発揮に対して果たす役割は大きい。また、人材、研究資金、 研究機器などの研究資源の確保、ステークホルダーのネットワーキングにおいて、継続性に よる優位性があることが観察できた。ICH S7B/E14では、日本側では E14 の国内移行が遅 れたことにも原因があるが、ICH-EWG の下部組織的となる日本側のカウンター組織が継続 的に存在しえなかったことにより、2 周目のサイクルにおいてイニシアティブをとることが できなかった。

・レギュレーターと境界組織の戦略共有 : アメリカは after 段階におけるルールの作動状況の モニタリングによりを検証しており、これにより次の戦略変更に貢献し、継続して次のトピ ックを創出するイニシアティブを発揮した。例えば、HESI はS7B/E14 が合意された後でも、 モニタリングを継続し、新しい技術を導入したガイドラインを作成する次のトピックへの前 段階（Before-2）に繋がり、E14 の廃止とS7B の改定の提案に貢献した。また、FDA の戦 略と連携し、境界組織側が科学的な可能性を探るための課題を共有するために、FDA とのシ ンポジウムの共同開催、データベースの共同作成が行われた。その間、境界組織側に暫定的 な WG が派生して、重要事項の根回しが行われる場合もあり、ヒト iPS 細胞由来心筋細胞に よる心筋毒性の測定や in silico の技術進歩により、before2 の段階でもイニシアティブを引 き続きとることができた。 
【参考文献】

[1] Guston H.David, 1999. "Stabilizing the boundary between US politics and science: the role of the Office of Technology Transfer as a boundary organization, Social Studies of Science, 29(1), 87-112

[2] Guston H.David, 2003. Principal-agent theory and structure of science policy, revisited: 'science in policy' and US report on Carcinogens, Science and Public Policy, 30(5), 347-358 [3]林裕子、日米のヒトゲノム計画に見る日本の科学技術政策決定過程に関する媒介機能とその課 題、研究技術計画 21(2), 202-213, 2007

【本研究の成果発表】

<論文>

(1) Hayashi,Yuko; Kano,Shingo(2015) "Policy value chain of making regulation in ICH

S7B/E14", "12th International Conference on Innovation and Management" <学会発表 $>$

（2）林裕子(山口大)，加納信吾（東大），「境界組織に着目したレギュレーターとイノベーター間 相互作用の分析フレームワーク構築」, 日本 MOT 学会 2013 年度年次研究発表会要旨集、於東京 理科大学、2014 年 3 月 15 日

（3）林裕子(山口大), 加納信吾(東大)，「戦略的レギュレーションがもたらすイノベーション：先 端医療を事例として」, 日本 MOT 学会 2013 年度年次研究発表会要旨集、於東京理科大学、2014 年 3 月 15 日

（12）林裕子(山口大)，加納信吾(東大)，「医療分野の国際ルール組成における境界組織の分析

-ICHS7B/E14 を事例として-」, 日本 MOT 学会 2014 年度年次研究発表会要旨集、於東京大学、 2015 年 3 月 14 日

(13) 林裕子(東大), 加納信吾(東大),「先端医療のレギュレーション策定における媒介機能の分析」, 2015 研究・技術計画学会要旨集 30：15-19,於早稲田大学、2015 年 10 月 11 日

（17）林裕子（山口大学） “Policy value chain of making regulation in ICH S7B/E14”，第 12 回 International Conference on Innovation and Management, Wuhan University of Technology(中国) 2015 年 11 月 21 日 (土)

(21) 林裕子(山口大), 加納信吾(東大), 政策バリューチェーンにおける媒介組織・機能の変遷, 第 31 回研究・イノベーション学会年次学術大会 1A02、2016 年 11 月 6 日(予稿集提出 9 月 30 日) (22) Yuko Hayashi(山口大), US-Japan Comparative study on strategic regulation of new Biomedical Technologies - A case study on Microarray, International Conference on Innovation and Management, Nov. 17-19, 2014, Vaasa, Finland

\section{2-2-6. 機能軸 : 薬事規制と技術標準のリンケージ}

医療分野における米国のガイドラインでは、自国メーカー等に有利なルールとして発行された 国際規格（ISO 等）を直接引用して策定するケースがみられ[1]、国際ルールの策定と国内ルール の策定が一体化され、戦略的に自国のガイドラインを策定する傾向を有する。このように、各国 の規制当局によるガイドラインに任意規格（自国メーカー等に有利な国際規格等）が引用される ことによって、事実上の強制法規化（デファクトマンダトリー化）がなされることは、医療分野 に特有であることが報告されている[2]。これを受け、先行研究では、医療分野の規制（薬事規制 等）と技術標準の相関性の検証として、薬事法の認証基準告示において、医療分野の JIS 規格 459 件のうち 195 件が引用されていることが報告されている[2]。

しかしながら、この報告[2]での分析は、薬事法の認証基準告示（ガイドライン）に引用された JIS、ISO、IEC の引用件数の集計にとどまっており、ガイドラインを構成する引用文献を包括的 
に検証したものではなく、個々のガイドラインがどのような薬事規制と技術標準を引用している かを、他のガイドラインとの相対的な関係を含めて明らかにした報告は未だない。

そこで、当グループでは、日本の薬事規制として、次世代医療機器・再生医療等製品評価指標 を事例として選択し、これらのガイドラインに引用されている国内外のガイドライン、国内外の 規格、論文、書籍等の文献を分析寸ることにより、近年の日本における製品特異的なガイドライ ンにおける薬事規制と技術標準の関係性を明らかにするあと同時に、ガイドラインが技術特性に よってどのように異なるかを解析することを目的とした(図 22)。

製品/サービスを取り巻く「ルールの束」/ 薬事規制と技術標準

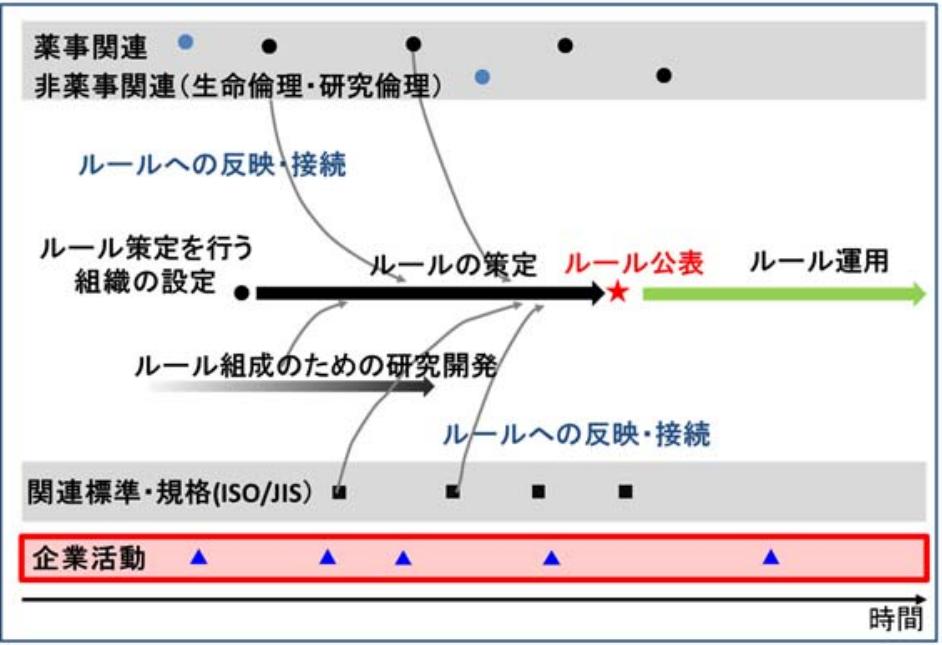

図 22 ガイドラインと技術標準の引用関係

事業開始年度である 2005 年から 2016 年 9 月現在に至るまでに厚生労働省及び経済産業省にて 合同で検討を進められ制定された、次世代医療機器・再生医療等製品評価指標（開発ガイドライ ン 36 件）を選択し、これらの指標が引用する国内外の規格、国内外の関連ガイドライン、書籍、 論文等の文献を抽出し、抽出した文献を、(1)国際規格（ISO、IEC、ASTM のいずれかに分類された 規格)、(2)JP 規格（JIS、日本国内における業界基準のいずれかに分類された規格）、(3)US 規格 (ANSI、 AAMI、UL のいずれかに分類された規格)、(4)EP 規格（RoHS 指令のみ）、(5)JP ガイドライン（日本 政府により制定された関連ガイドライン)、(6)US ガイドライン（米国政府により制定された関連 ガイドライン)、(7)EP ガイドライン（欧州政府により制定された関連ガイドライン）、 8)論文・書 籍（国内外を問わない専門家により執筆された論文・書籍）の 8 つに分類し、各分類における引 用件数を算出し、各 GL を因子分析の第一因子、第二因子によりクラスター解析した結果を図 23 に示す。

引用関係は、日本優位、新規出現分野、海外先行など技術の特徴を反映しており、引用関係に よりガイドラインがプロファイリングされる可能性が示唆された。

【参考文献】

[1]US Food and Drug Administration. Self-monitoring blood glucose test systems for over-the-counter use: draft guidance for industry and Food and Drug Administration staff. http://www.fda.gov/downloads/MedicalDevices/DeviceRegulationandGuidance/GuidanceDocu ments/UCM380327.pdf. Accessed April 8, 2014.

[2] 医療安全WG 中間報告書, 平成 24 年 12 月, 日本工業標準調查会標準部会, 医療用具技術専 門委員会

【本研究の成果発表】

<学会発表 $>$ 
（19）及び(19）-2 木戸舞(東大), 加納信吾(東大), 薬事規制と技術標準のリンケージ解析 -次世代医 療機器・再生医療等製品評価指標を事例に-, 第 31 回研究・イノベーション学会年次学術大会 $2 \mathrm{I} 04$, 於青山学院大学、 2016 年 11 月 6 日(予稿集提出 9 月 30 日)

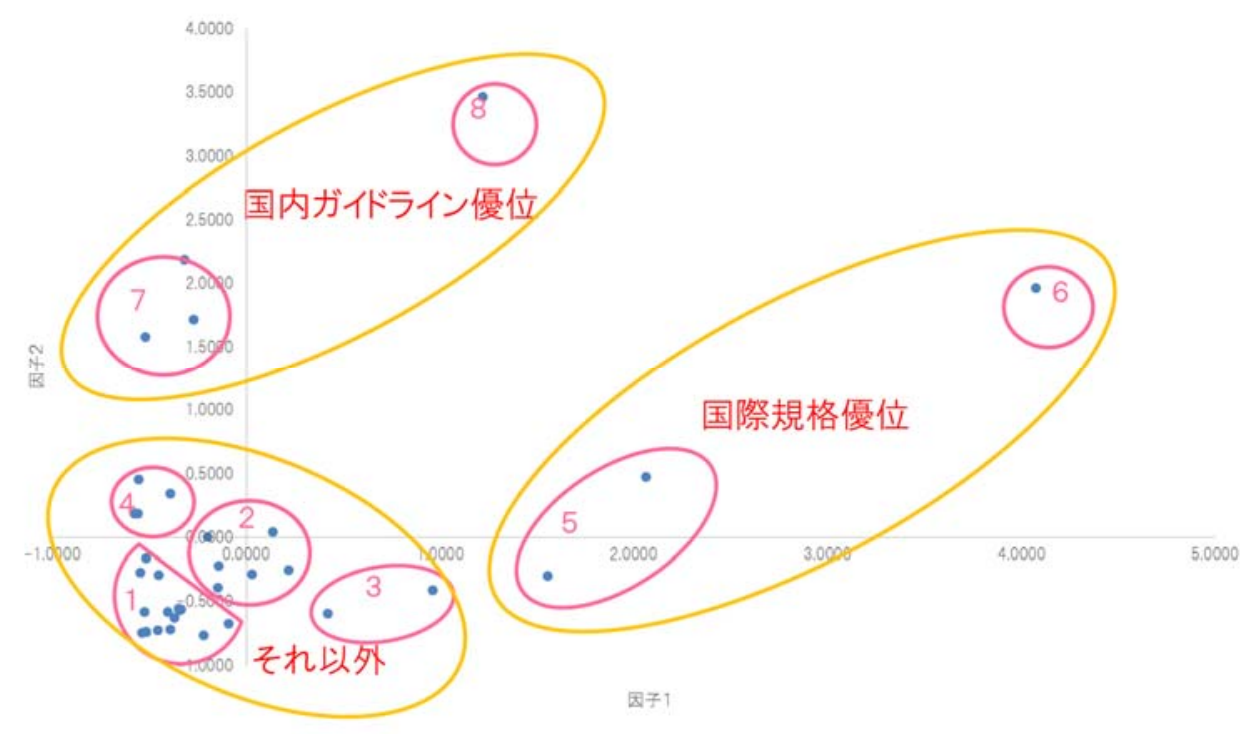

図 23 開発ガイドラインの引用関係によるマッピング

\section{2-2-7. 機能軸 : リーガル・パースペクティブ}

1)製品特異的なガイドライン整備の功罪

医療規制の組成における、製品特異的なガイドライン組成のヒストリカルビュー並びにその功 罪について精查し、今後の医療機器規制における製品特異的な規制整備の動向について検討した。

特に、米国における医療機器規制の変遷について、1976 年以前（医療機器の特性を踏まえた規 制のない時代）は医薬品規制が転用されたいたこと、1976 年以後（医療機器の特性を踏まえた規 制の導入された時代）は、市販前承認手続きが使われるのは 1 パーセントで、ほぼすべての医療 機器が $510 \mathrm{k}$ という手続きで市販される（審査は、すでに市販されている製品との実質的同等性 のみ）状態にあったこと、2012-2015 年の期間は、規制見直し、リスク分類の見直し \& 510Kの 申請要件の明確化、市販後調查の強化と効率化（UDIs）が実施されていることにつき、報告がな された（図 24）。

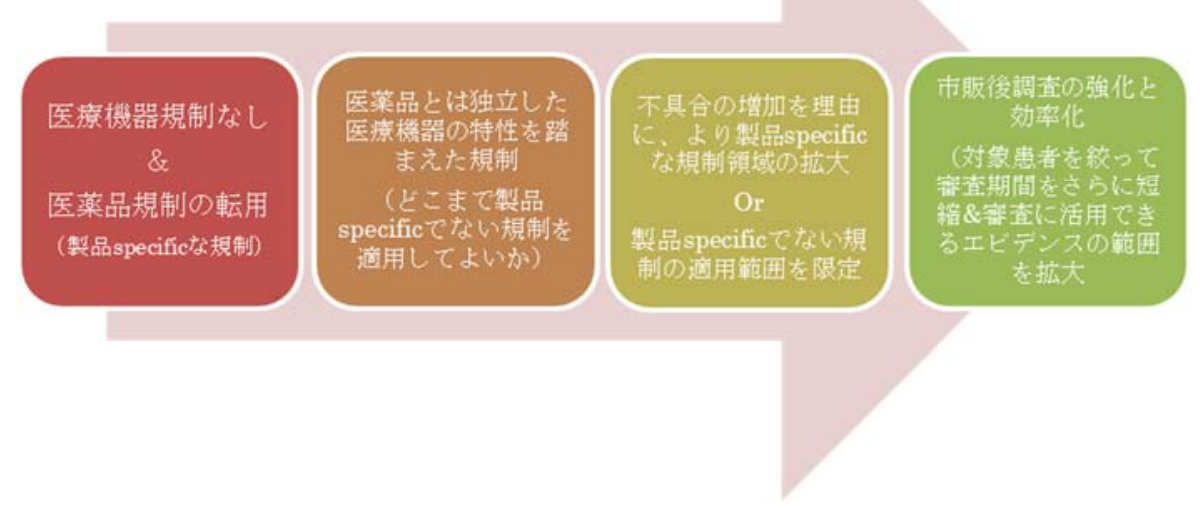

図 24 製品非特異的な規制領域の拡大の歴史 
米国は、510k: Pre-Market Notification（実質的同等性を審査すれども、個別の認証基準を作 るわけではない）を導入しており、審查期間は極めて短く、市販の 90 日前に通知して販売するこ とが可能となっている。費用は、およそ 1 万 8,200 ドル（2005 年）であり、特許延長制度の対象 外であることが特徵である。年間 3000 件の申請のうち 99 パーセントは、PMA ではなく $510 \mathrm{k}$ の手続きで市販されており、要件としては「これまで市販された製品と実質的に同等であること (クラス 3 の医療機器でも、3/4 はPMA を回避してこの手続きで販売)」となっている。

元来、1976 年以前に市販されていた機器に追加的な審査をしないで販売させる規制であったが、 この手続きがイノベーションを促進したと言われている。日本が医療機器規制においては、実質 的同等性に類似の概念を導入するか否かが今後の医療機器におけるルール組成上の一つの課題と される。

製品特異的なルールの組成限界を考慮すると、今後の効率的なルール体系の整備とイノベーシ ヨンの促進という観点からは、CE マークによる認証を行う欧州型とも異なり、今後のルール組 成上、レファレンスとしての $510 \mathrm{k}$ についての検討を実施した。

2)新規の規制整備の法的枠組み

リーガル・パースペクティブでは、タイムリーかつより適切な内容の規制が探求され続けるよ うな制度設計について、主に行政手続と行政組織の 2 つの観点から改善策の案を提示する。より 具体的にいえば、現行法の行政手続法と国家行政組織法について改善すべき点について説明する。

1 つ目の行政手続きの面では、ある政策を実装する際に複数の代替的政策と比較分析すること が義務付けられていく方向性が重要だと考えられる。そもそも、規制タイミングを最適化してい くためには、過去から将来にかけて政策を追跡して、よりよい現実的な政策を実現し続ける必要 がある。もっと言えば、そのようなインセンティブを法的に生み出しておく必要があるものの、 現時点では十分なインセンティブが存在していない。たとえば、これまで日本における規制では、 ある場面では立法主導で、他方、大多数の場面では既存政省令の改正という形をとって、目の前 の課題への対応が重視されてきた。それは、立法については違憲にならない内容であればよく、 行政立法やガイドラインの策定では法律による行政の原理に反しない限り、目の前の課題対応に 最も効果的な方法を採ることが官僚にとっては望ましいからである。担当部署での任期が 2 年か ら 3 年と短い官僚にとって最も重要なのは、目の前の課題に対応することであって、よりよい規 制を追求していくことではない。

行政手続法において、ある政策を実装する際に複数の代替的政策と比較分析するプロセスを経 ると、これまで法律と政省令の両方の制定に深く関与してきた官僚の役割について、大きな変化 が見られることになるだろう。すなわち、法律と政省令を融通無碍な道具として使い、目の前の 課題対応に奔走させるのではなく、法律による行政の原理のもとで、よりエビデンスベイスドな 政策形成によって絶え間なくよりよい規制内容を探求する役割を担うことができるようになる。 官僚にしてみれば、国民の代表者から構成される国会には大枠だけの内容からなる法律を承認し てもらい、当該法律で詳細については政省令へ委任し、それでも残されてしまう点については官 僚の裁量で処理するのが現在の行動原理である。これは、法律による行政の原理からの要請であ ると同時に、目の前の政策課題を円滑に処理していくためには当然のことと言える。他方、官僚 が法律の起草から梁くコミットし、政省令とガイドラインで法執行においても責任を負うとすれ ば、政策の実装後に法令の中身や法執行について法的な責任が問われる余地は大きくならざるを 得ない。しかし、政策を実装する際に複数の代替的政策と比較分析するプロセスを経ることは、 行政手続きとして他の代替案と比較の上で、合理的な注意を払ってよりよい政策を実装し続ける ための証跡が明確に残ることになり、これまでよりも官僚ないし行政機関の過失責任を軽減する 方向につながるだろう。

なお、ある政策を実装する際に複数の代替的政策と比較分析することが義務付けられていく方 向性は、すでに米国でも欧州でも見られる。米国では行政手続法 (Administrative Procedure Act) 


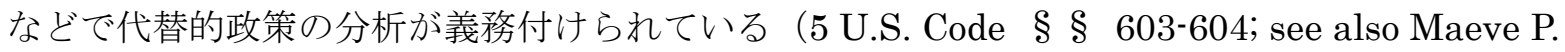
Carey, Cost-Benefit and Other Analysis Requirements in the Rulemaking Process, Congressional Research Service Report, R41974, Dec. 9, 2014)。また、欧州では欧州議会手続 き規則（Rules of Procedure of the European Parliament）における立法手続き上の財源と補完 性確認に加えて、欧州委員会で 2015 年に「よりよい規制に関するガイドライン」（Better

Regulation Guidelines）が制定されている。

$2 つ$ 目の行政組織の面では、国家行政組織法において省庁を跨ぐような境界組織について規定 を置くことが考えられる。これまでは行政組織のスリム化の観点から、独立行政法人の活用が進 められてきた。しかしながら、先端医療分野については内閣の統轄の下に、企画、運営、そして 国の行政機関相互の調整という行政機能を一体的に発揮するような新しい境界組織が想定される べきものと思われる。

本研究では、米国のようにシンクタンクのような民間の境界組織を作るという提案に加えて、 行政組織としても境界組織を生み出しうる可能性を模索した。確かに、内閣官房健康・医療戦略 室のように個別の法律に基づいてパッチワーク的に境界組織を作り出すことは現在でも可能であ る。しかしながら、より一般的な組織法の中に、境界組織が一定の要件の下で設置しうることを 明らかにし、その要件と境界組織が備えるべき内容について定めておくことができれば、先端医 療の発展においてよりタイムリーな政策の実装が可能となる。本研究では、境界組織が備えるべ き性質や役割を分析しており、このようなエビデンスに基づいて国家行政組織法に境界組織の設 立が裏付けられれば、先端医療に関するより優れた行政組織の設立やファンディングの運用は一 段と改善されうるものと思われる。

最後にまとめになるが、行政手続と行政組織における改善すべき点は、どちらも行政の裁量を 縛るようでいて、実は法律による行政の原理のもと、政策の可能性をより大きくするものである。 確かに一見すると、官僚の裁量は行政手続法と国家行政組織法の改正によって制限されるように 思われなくもない。しかしながら、場当たり的に、目の前の課題対応のための法律を起草する傾 向があるのが官僚組織で、政省令やガイドラインを通じて自由自在に運用するのも官僚という世 界では、政策に対する予見可能性は著しく低くなり、先端医療分野への投資に影響が生じてしま う。また、それは同時に官僚や行政機関の責任を召致する可能性さえある。行政手続と行政組織 について、行政手続法と国家行政組織法の改正することは、官僚と行政機関が法律のもとで裁量 を行使し、最善の政策を探求し続けるインセンティブを生み出す第一歩であり、究極的には実証 的な証拠に基づく政策の実現に繋がるものつながるものと思われる。

\section{2-2-8. 政策提言の準備 : シナリオプランニングの利用に関する検討}

シナリオプランニングをベースにした政策提案を実施する場合に、重要で不確実な要因と提案 すべき政策との関連性を明確にする必要がある。本プロジェクトでは、各シナリオに共通する事 象として、フォワード・シナリオプラニングにおけるシナリオと政策提案との関係について議論 し、本プロジェクトの立場は、「シナリオ分岐に対する介入に必要な政策」を「政策パッケージ」 として捉え、シナリオ・ロジック（シナリオ分岐の組合せ）を望ましい分岐に誘導することが求 められる政策であり、提案されるべき政策のもっと大きな枠組みは、「シナリオ分岐」VS「政策 パッケージ」の対応関係で検討を進める点について、プロジェクト内で合意形成を行った(図 25)。 


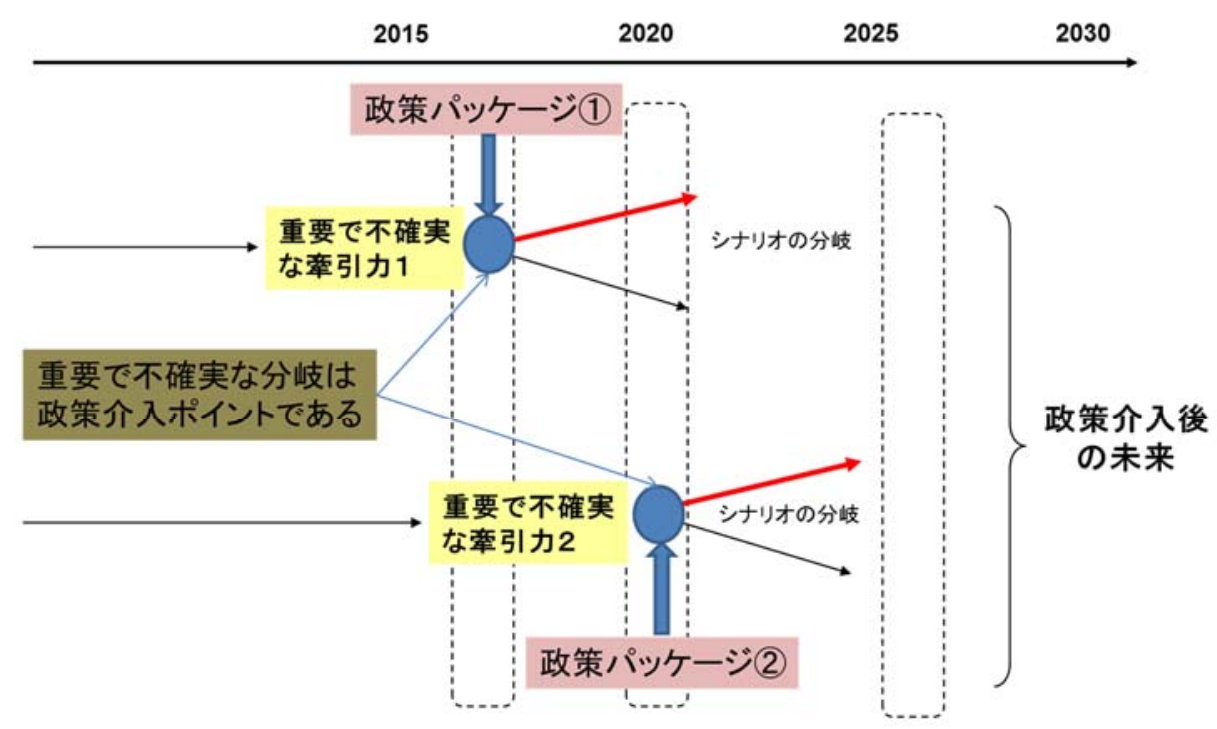

未来は、「政策介入」によって、特定の方向に誘導される

図 25 シナリオ分岐と提案される政策パッケージ

また、政策パッケージは最上位のシナリオ分岐を構成する、独立事象としてのシナリオ分岐事 象と、その独立事象に連動して変動する従属事象は同一の政策パッケージ内に含まれることから、 「分岐＝政策パッケージのターゲット」として、個別の詳細な政策ではなく、「重要で不確実な分 岐」をシフトさせる政策群として想定することとした(図 26)。

ドライビングフォースの例と政策パツケージによる介入

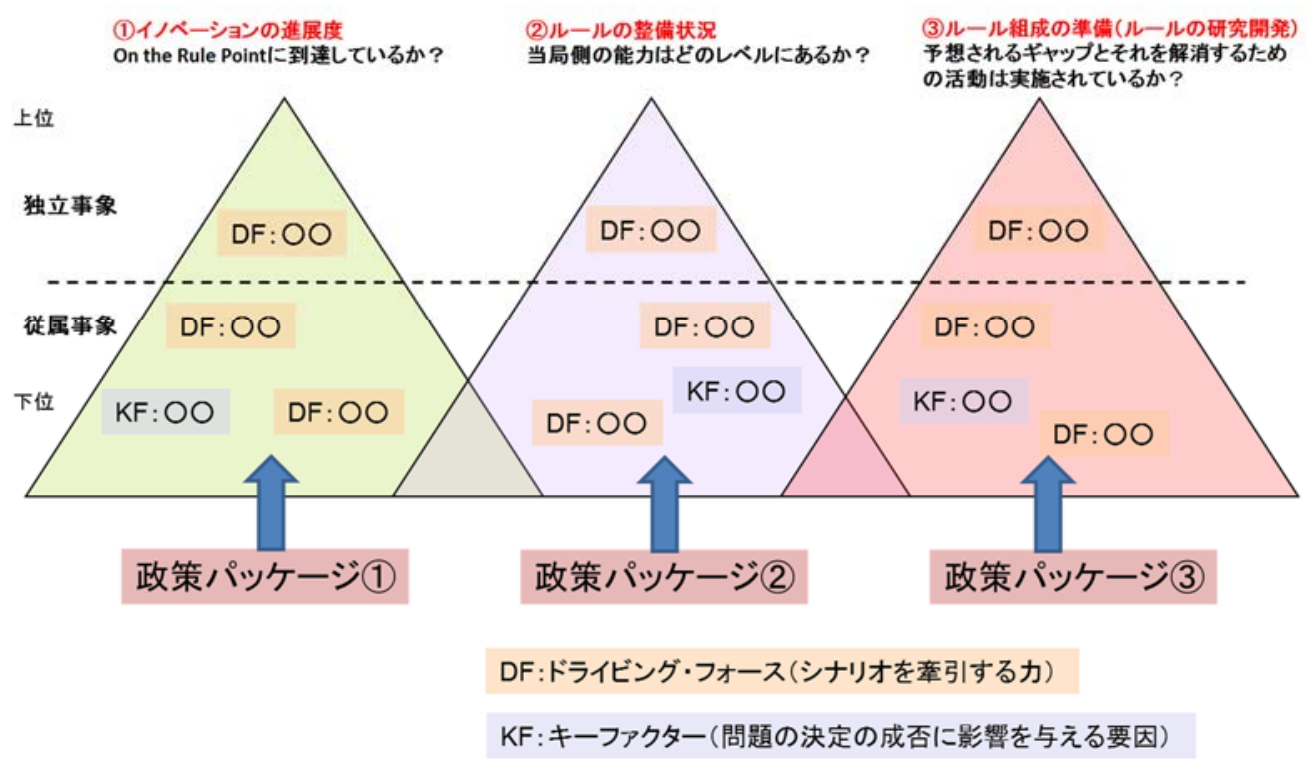

図 26 政策パッケージにおける独立事象と従属事象

例えば、個別化医療において想定された重要で不確実な分岐は、「医療費抑制」、「個人情報の利 用」、「技術標準化」であったが、政策パッケージとして目的記載されると、「医療費抑制効果のあ る政策群」がターゲットドメインとなり、数ある従属事象の中から、「医療費抑制効果のあるイノ ベーションの促進」が政策提案の一部となる。この取扱いは、 5 年〜 10 年先の将来シナリオに対 
応した政策提案における、記載内容の分解能をどの程度とすることが、政策研究者と政策立案者 とのコミュニケーションにおいて最適かという課題に対応するものであるが、政策効果のターゲ ットとす心゙き、「独立事象」と「従属事象」のパッケージに対する、打ち手を本プロジェクトでは 「政策パッケージ」と呼び、こうした分解能の妥当性を今後の政策立案者との対話により検証し ていくこととした(図 27)。

\section{重要で不確実な分岐に対する政策パツケージによる介入}

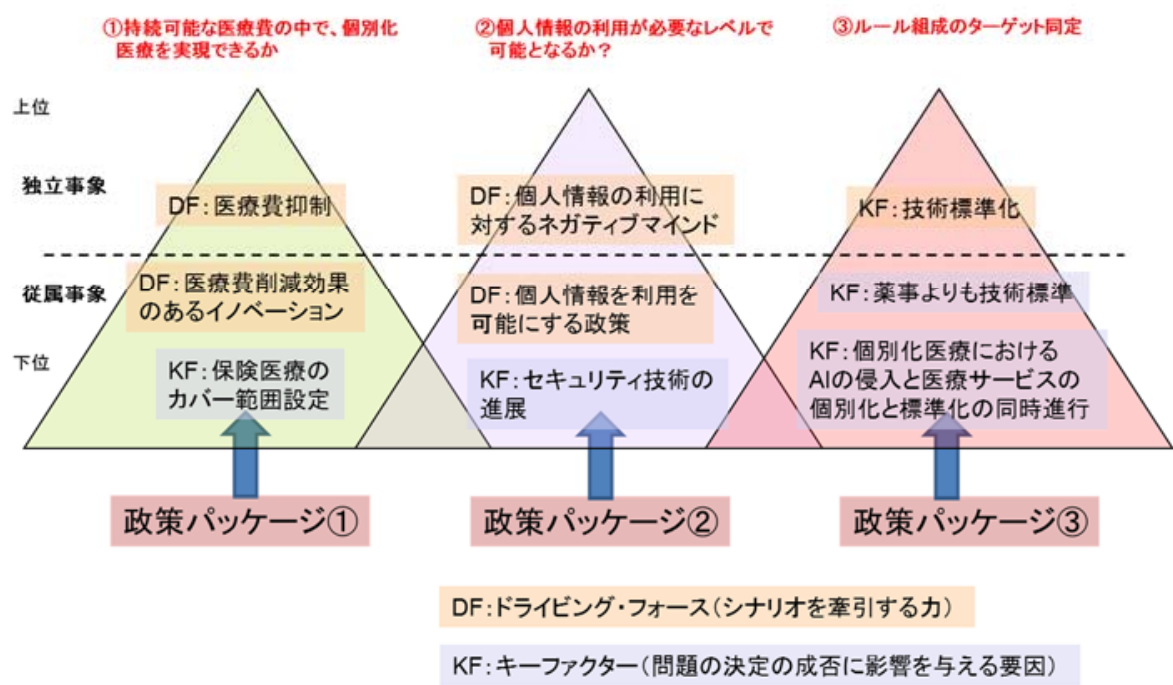

図 27 個別化医療シナリオにおけるシナリオ分岐と政策パッケージの例

\section{2-2-9. セクター軸 : 先端医療機器}

過去分析 : 薬剤溶出ステント,単体プログラム,径カテーテル大動脈弁治療(TAVI),カプセル内視 鏡, 手術用ロボット、医療機器のソフトウェアなどの様々なタイプの医療機器の事例解析を実施し た。医療機器においては、製品非特異的な医療機器の審査ルールの大枠が規定されており、これ に上積み寸る形で次世代医療機器ガイドラインにより製品特異的なガイドラインが整備されてい る一方で、既存承認製品を巧みに参照しながら申請された場合には規制当局の運用によって新類 型と解釈せずに対応している事例（径カテーテル大動脈弁治療(TAVI)）も存在している。医療機 器ではこのように新規性の解釈が難しい事例が多いことを事例から明らかにした。

医療機器分野においても、DDT ガイドラインに相当するガイドライン (Medical device development tool : MDDT)があり、 a clinical outcome assessment, a test used to detect or measure a biomarker, non-clinical assessment method or model を対象とした性能評価技術を 審査に使えるように促す仕組みを FDA は用意している。先端医療機器 G について MDDTを翻訳 するとともに詳細に分析している。

バックワード・シナリオプランニング : 事例分析を受けて、過去事例に対応したバックワード・ シナリオプランニングとしては、個別の医療機器を対象とするのではなく、新規性の高い医療機 器全体を対象とした全製品をカバーする分析フレームとし、(1)規制当局の新製品に対する方針 (製 品特異的ガイドラインを組成するか否か）を巡る選択と(2)新しい医療機器のコンセプトの完成度 により、分岐したとする過去シナリオを構築した(図 28-1)。

フォワード・シナリオプランニング : フォワード SP におけるテーマ設定は、先端的な医療機 器全般に該当する課題を取り扱うこととし、次世代医療機器評価指標に関する検討で課題となっ た、どこまで製品特異的なガイドライン組成を行うことが、先端技術の制御方法として妥当であ るのかという点が大きな論点のひとつとなった。このため、ルール組成のための政策リソースに 
限界のある中で、製品特異的ではないMDDT のようなホライゾンタルルールの有用性が着目され、 シナリオ分岐のひとつとして採用されることとなった。製品特異的ルールについては、製品の新 規性と類似性の境界の判断が難しく、この点についての検討は、リーガル・パースペクティブ G で検討を実施した。また、厚生省が提唱しはじめた、国際的なイニシアティブについても日本製 品の海外市場確保との関連性からその重要性が検討され、シナリオ分岐に採択された。また、製 品開発の促進という観点からは日本における価格設定の予測性が低い点が問題視され、この点も シナリオ分岐に組み込まれた。最終的に、「妥当な価格ロジックの構築」、「国際的なイニシアティ ブと市場確保」、「製品多様性に対応できるホライゾンタルルールの組成」の 3 つをシナリオ分岐 として想定した(図 28-2)。

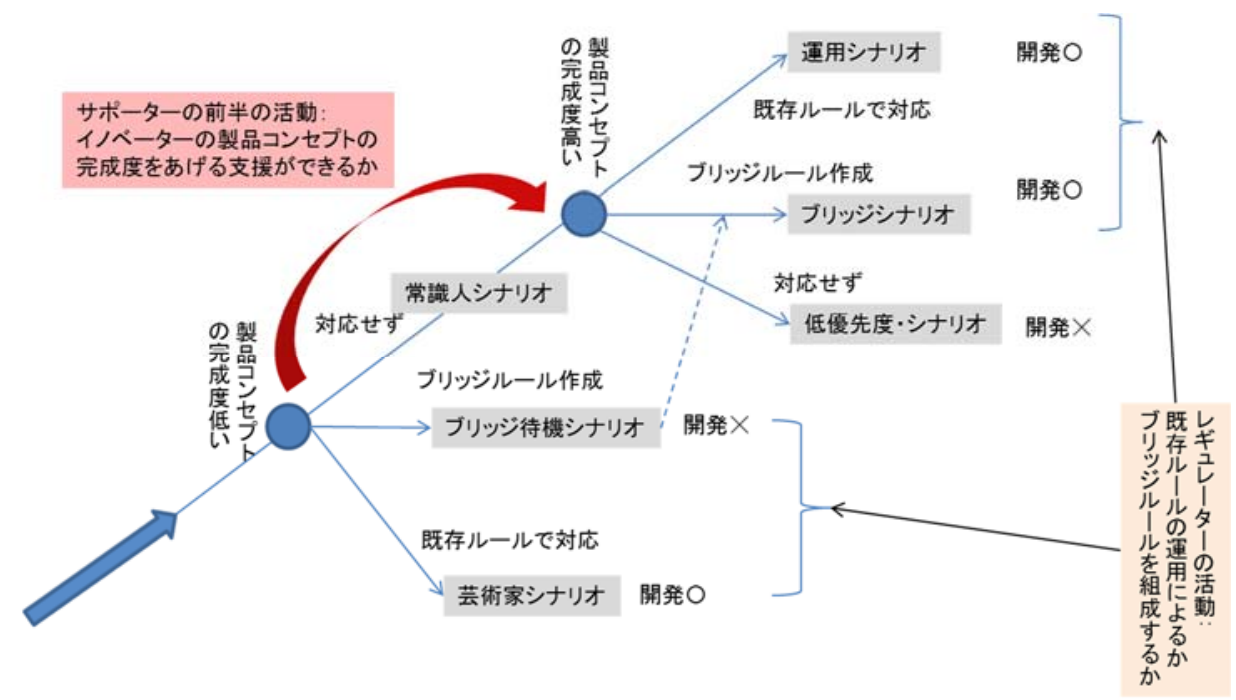

図 28-1バックワード SP : 先端医療機器におけるシナリオ分岐

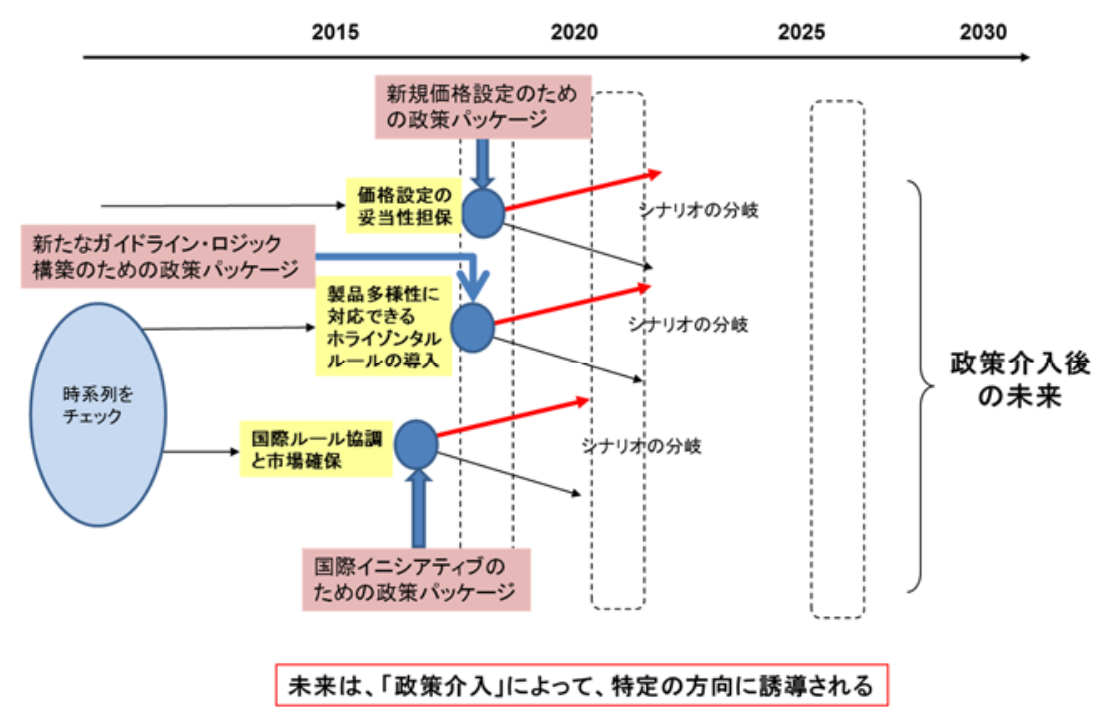

図 28-2 フォワード SP : 先端医療機器におけるシナリオ分岐

$3 つ$ る分岐から、優先順位をつけて 2 つを選択し、将来シナリオとするという本プロジェク トのやり方では、 3 通りの 2 つの選択が存在することになるが、価格設定の妥当性、国際的なイ ニシアティブの 2 つを選択すれば、図 29 のように、「両刃の剣シナリオ」、「出稼ぎシナリオ」、「国 
内メリハリシナリオ」、「縮小均衡シナリオ」の 4 つが生成された。

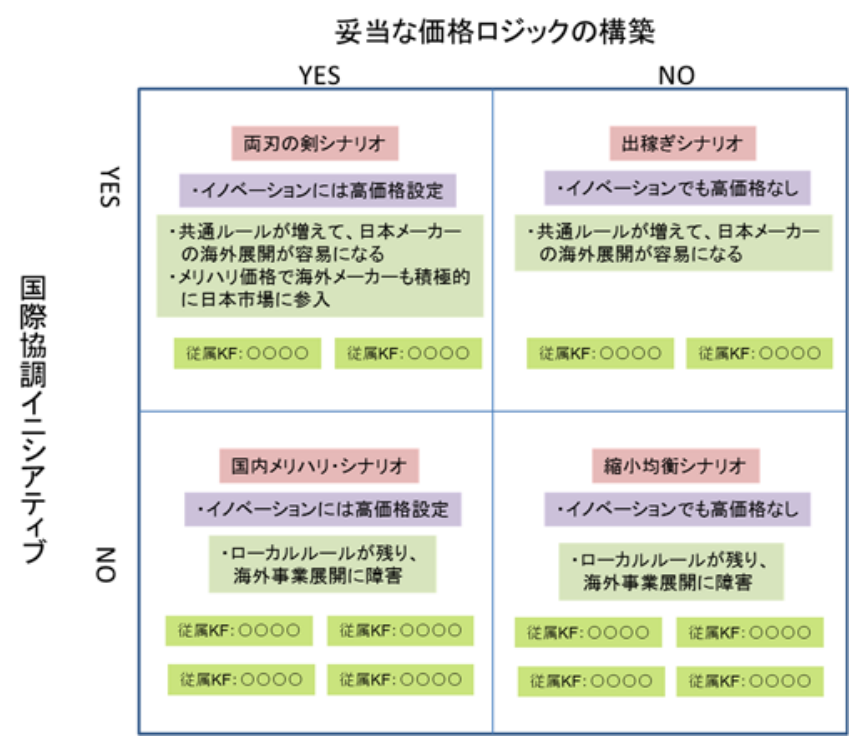

図 29 フォワード SP : 先端医療機器におけるシナリオ・ロジックの例

\section{2-2-10. セクター軸 : 再生医療（治療）}

過去事例 : 成功例 4 件（培養軟骨、培養皮膚、がん免疫療法 2 件）、失敗例（角膜）を選択し、 詳細なルールマップの作成(非薬事、薬事、技術標準)、時系列解析、境界組織分析を実施した。

また、再生医療におけるルール組成の国際比較を実施するため、製品軸と情報軸から統一的に 比較制度分析を実施するフレームワークを構築し、日米欧における再生医療分野での技術の制御 スタイルの違いを明らかにした(文献(10))。

バックワード・シナリオプランニング : 薬事法ルートもしくは医師法ルートの選択、規制当局 とのコミュニケーションの 2 つを分岐として選択した（図 30）。また、当局とのコミュニケーシ ヨンについては regulatory space 上での相互作用の評価を実施し(図 31)、ルートの選択問題につ いては別途事例解析を実施した（論文(20)）。

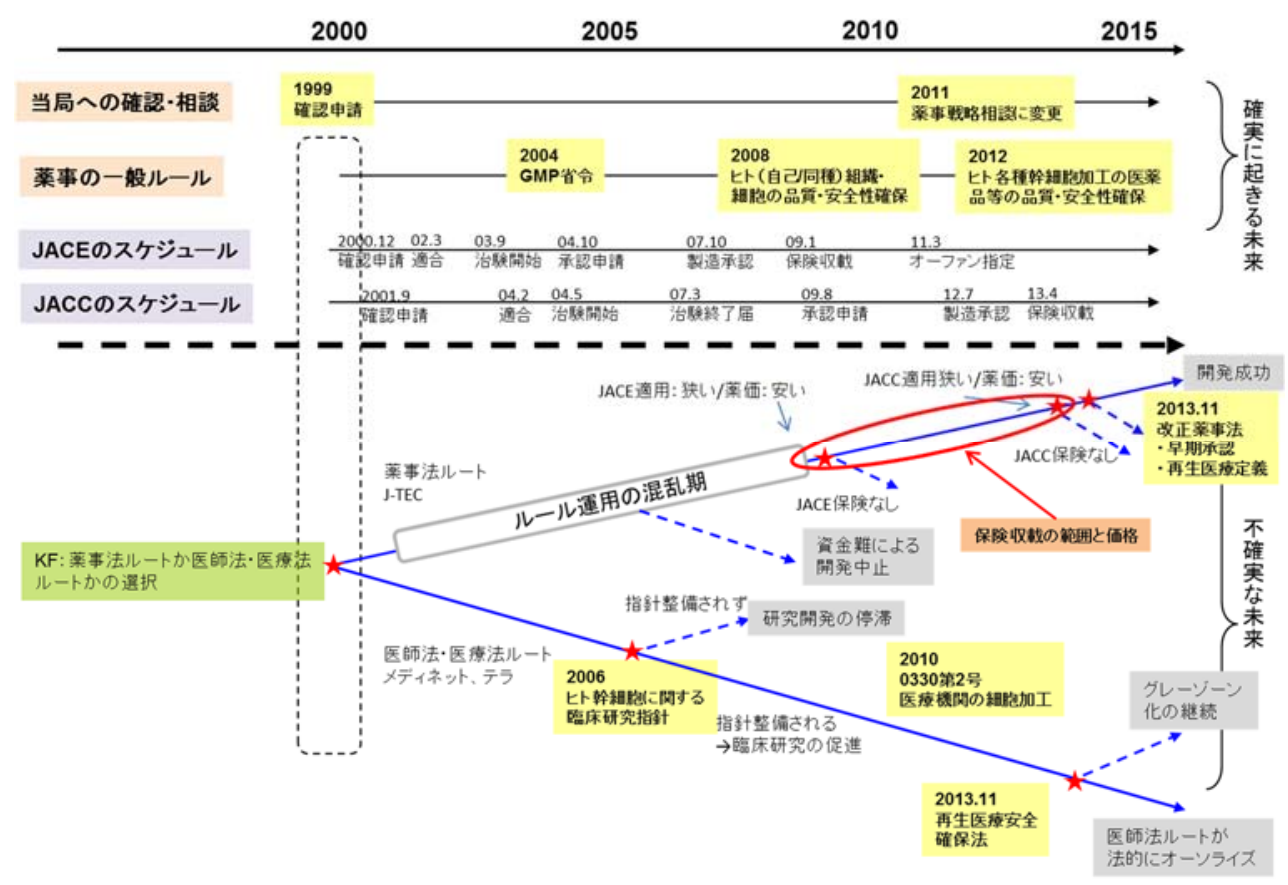

図 30 バックワード SP : 再生医療治療(1999-2015) 
フォワード・シナリオプランニング : 未来事例の選択においては、再生医療における最も重要 な論点は、過去事例と未来事例の間に大規模な法改正があることから、現在と未来の間の接続可 能なモデルは想定されなかったこと、一定のルール整備がなされた結果、今後の課題はルールの 整備よりも藏器誘導後の評価技術の有無とその運用にあり、また、治療がどの程度、保険の償還 対象となり得るかであり、また幹細胞そのものの安全性基準の策定よりも個々の再生医療の治療 手段に対する安全性基準を整備するための評価技術の開発と評価技術に基づく基準の整備が重要 であるとの判断に至った (専門家意見)。

したがって、イノベーション側の進展としては、適用疾患の優先順位、安全性の確認方法（イ ノベーター・レギュレーター両者)、バンクの利用による自家から他家へのシフトなどが候補とな つた。レギュレーター側の進展としては、新法下の運用体制（特定認定等再生医療委員会と厚生 科学審議会）と運用内容、安全性の確認方法（イノベーター・レギュレーター両者）、ISO の整備 が再生医療の進展にどう影響を与えるか、ガイドラインにおける一般記載と個別記載の切り分け の見直し、医療経済的な側面としては、保険医療における対価設定などがキーファクターやドラ イビングフォースとしてリストアップされた。

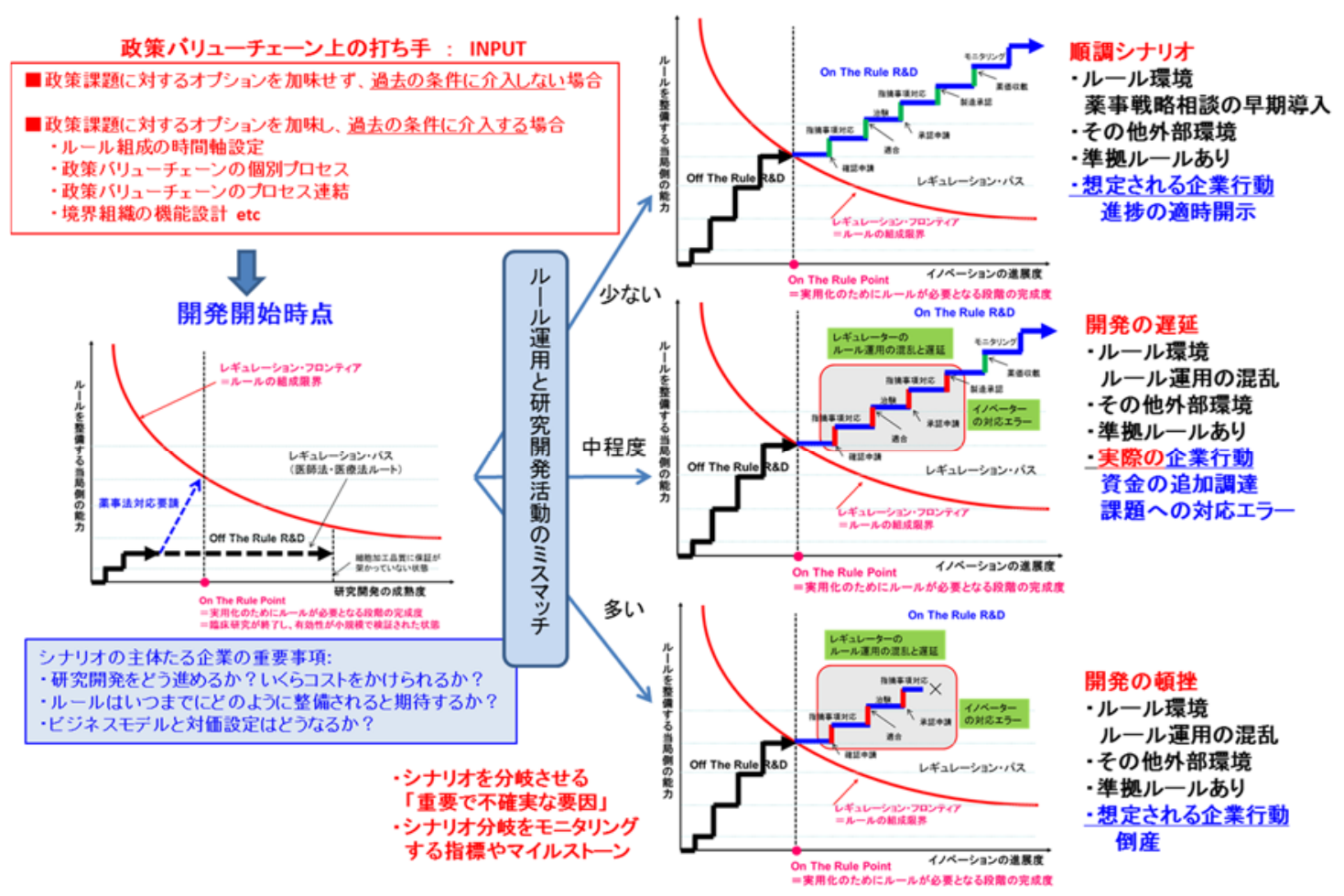

図 31 バックワードSP のシナリオ分岐の詳細と regulatory space

全体としては、iPS 細胞を活用した臨床応用の個別の事例の選択も候補にあがったが、現状で は最も進んでいる加齢黄班変性症も含めて、安全性の評価技術の妥当性評価が「最重要の一般化 された課題でかつ不確実」との指摘もあり、シナリオ分岐としては、安全性評価技術の開発を重 要で不確実とした。将来シナリオとしては「保険カバー範囲」と「アプリケーション別の安全性 基準の整備」をシナリオ分岐とするシナリオを想定した（図 32)。求められる政策パッケージは、 安全性評価技術を確立させるための評価技術ガイドライン整備、評価技術の研究開発の促進、保 険のカバー範囲を拡大寸るための、コストダウン技術の開発への研究費補助である。 


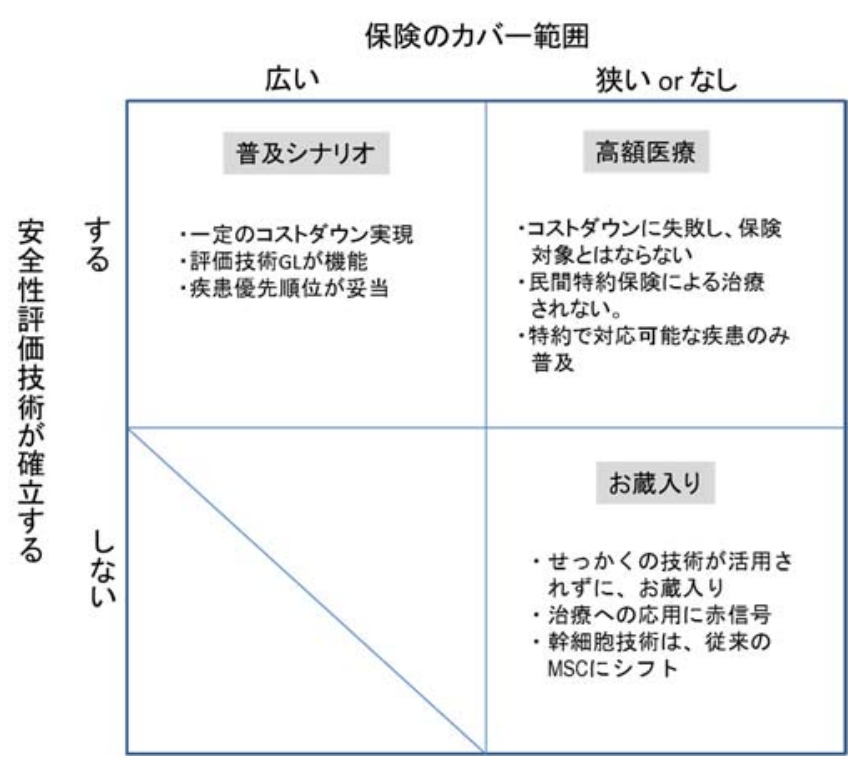

【本研究の成果発表】

図 32 フォワード SP : 再生医療・治療

<論文 $>$

(2) Kuni Itoh and Shingo Kano (2016), Comparison of international guidelines for regenerative medicine: knee cartilage repair and replacement using human-derived cells and tissues, Biologics, Volume 44, Issue 4, July, Pages 267-270 <学会発表 $>$

（10）伊東久仁(東大)，山中隆幸(東大)，加納信吾(東大)，「日米欧 再生医療関連ガイドラインの国 際比較 ガイドラインの分析フレームワークの構築」, 日本 MOT 学会 2014 年度年次研究発表会 要旨集、於東京大学、2015 年 3 月 14 日

\section{2-2-11. セクター軸 : 再生医療（ツール）}

過去事例：ICHS7B/E14（医薬品の心筋への安全性に関する国際ルール）新規評価技術のルー ル組成への組込みに関する理想モデルを構築した（2-2-5 : 機能軸 : 国際ルール化を参照）。

バックワード・シナリオプランニング : 理想モデルに基づいてバックワード SP を実施し、境 界組織の継続性が極めて重要でかつ不確実であり、これにより過去は分岐していたと想定し、継 続性がモニタリングや情報共有にも連動しており、これを実現するための政策課題の抽出（境界 組織強化のための政策）を実施した（図 33）。

フォワード・シナリオプランニング : 過去分析から導出した「ガイドライン作成サイクル」を モデルとして採用し、第一サイクル（過去）を ICHS7B/E14 の整備、第二サイクル（近未来）を ICHS7B/E14 の修正、第三サイクル（長期）を拡大型の安全性薬理ガイドラインとした。

・未来シナリオ(1) : 技術融合による次期 ICH 改定（第三サイクル）

現在の ICHS7B/E14 の改定作業(第二サイクル)の後にくる、各種技術融合が起き得るかという シナリオ分岐と、日本が単独でもルール化にチャレンジするかというシナリオ分岐の組合せが未 来を決めるというマトリックス型の 4 つのシナリオを提案した。図 32 に示したマネジメント要因 については、各種要因を統合して、レギュラトリー・リサーチ・エンジンが機能するか否かが未 来のシナリオを分けるとした(図 34)。Inside-out 型の医薬品ルール組成を実施する場合にはその ための科学的根拠と協力な GL 組成能力以外にも、日本単独で進むだけの判断が求められるが、 これはレギュラトリー・リサーチ・エンジンの強化とも連動している。 


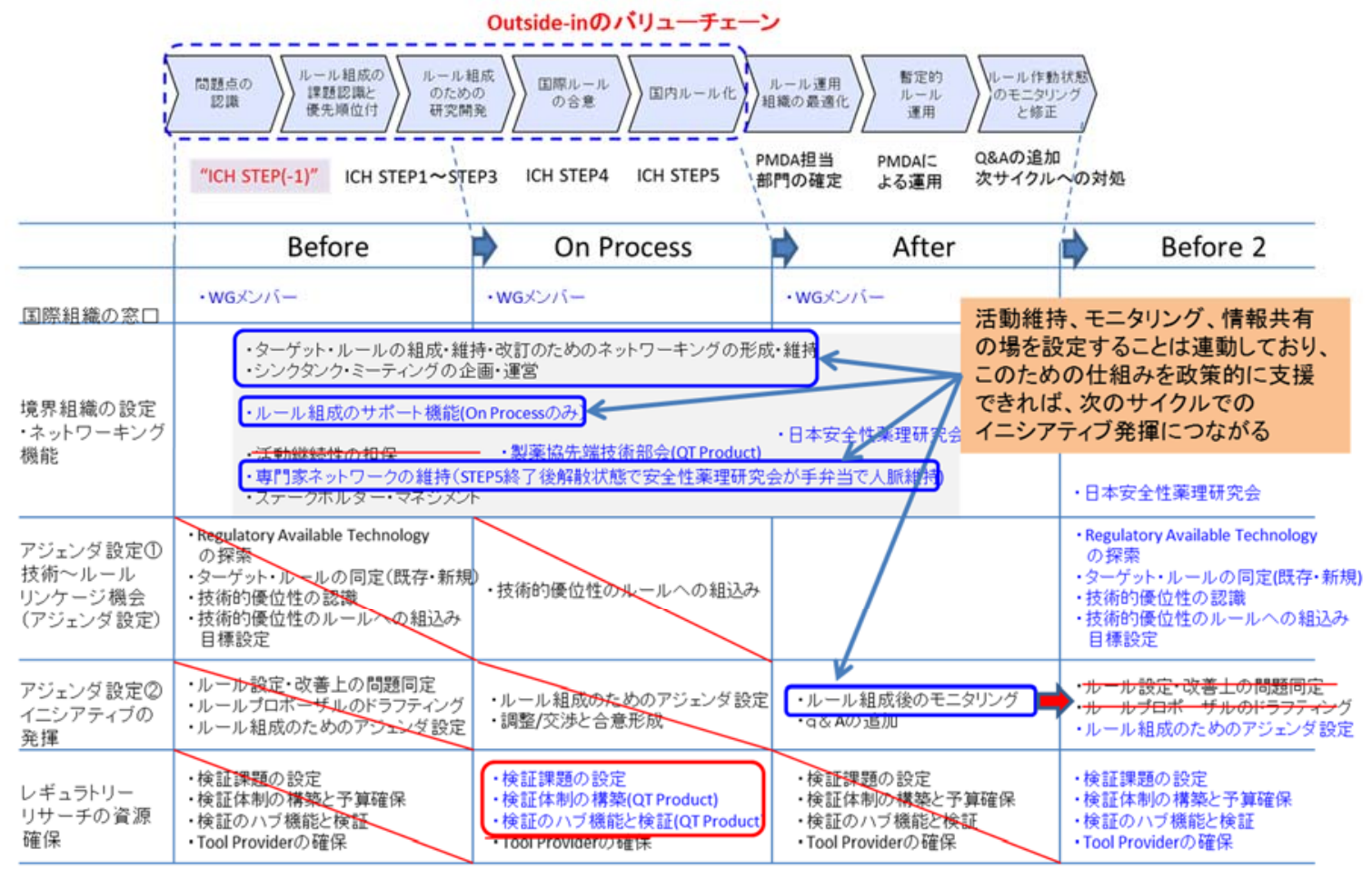

※青字は日本側で成立したもの

図 33 バックワード SP : 再生医療ツール（心筋毒性）（青枠が分岐候補）

第三サイクル:フォワード・シナリオプランニング: 案1

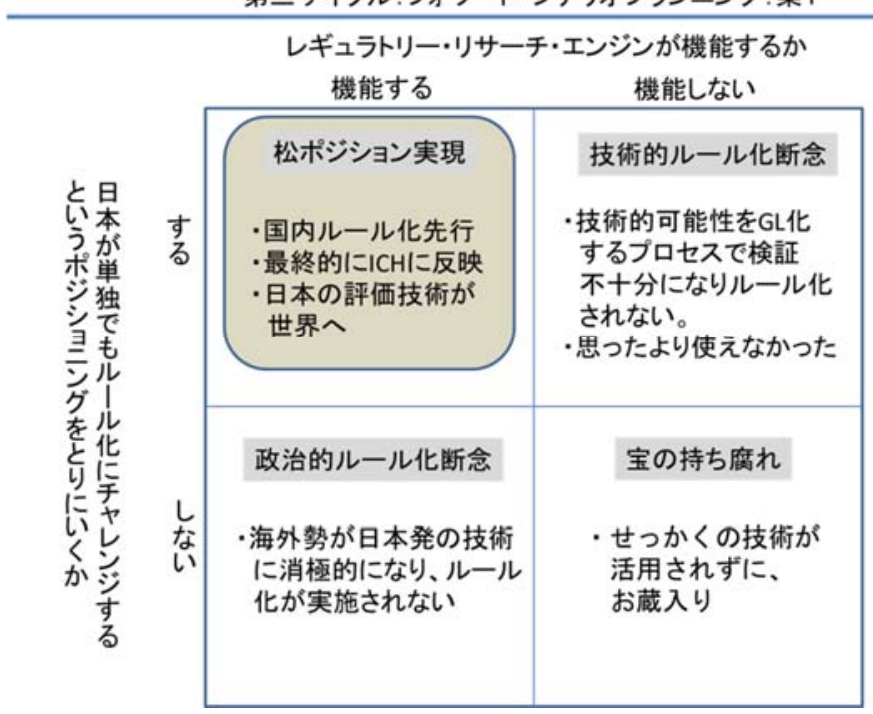

図 34 フォワード SP : 再生医療ツール : 技術融合による次期 ICH 改定のシナリオ分岐

・未来シナリオ(2) : 新パラダイムの創設（第三サイクル拡張版）

更に時間軸を長くした場合、安全性薬理試験の新パラダイム提唱に向けた将来シナリオを検討 し、「個別化安全性薬理パラダイムの追求」「レギュラトリー・リサーチ・エンジンが機能するか」 で未来が分岐することを提案した（図 35）。「パラダイムの創設者」、「アイデア倒れ」、「米国追従 型」、傍観者」の 4 つのシナリオを提示した。求められる政策は、新規パラダイム追及一の政策 支援並びに、レギュラトリー・リサーチ・エンジンの強化である。 
【本研究の成果発表】

<学会発表 $>$

（12）林裕子(山口大), 加納信吾(東大)，「医療分野の国際ルール組成における境界組織の分析

-ICHS7B/E14 を事例として-」, 日本 MOT 学会 2014 年度年次研究発表会要旨集、於東京大学、 2015 年 3 月 14 日

（17）林裕子（山口大），“Policy value chain of making regulation in ICH S7B/E14”，第 12 回 International Conference on Innovation and Management, Wuhan University of Technology （中国） 2015 年 11 月 21 日 (土）

\begin{tabular}{|c|c|c|c|}
\hline \multirow{10}{*}{ 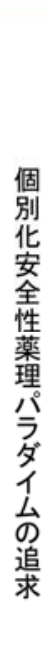 } & & \multicolumn{2}{|c|}{ レギュラトリー・リサーチ・エンジンが機能するか } \\
\hline & & 機能する & 機能しない \\
\hline & & バラタイムの創設者 & アイデア倒れ \\
\hline & $\frac{d}{3}$ & 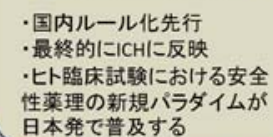 & $\begin{array}{l}\text { •パラタイイをGL化するプロセ } \\
\text { スで䐿証不+分になりルール } \\
\text { 化されない。 }\end{array}$ \\
\hline & & IETKF:0000 & 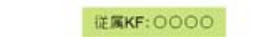 \\
\hline & & 隹两DF: 0000 & 徤面DF: 0000 \\
\hline & & 米国追従型 & 傍観者 \\
\hline & 孛 & $\begin{array}{l}\text { ·現状の延長線上にある } \\
\text { 課題のみか処理される }\end{array}$ & $\begin{array}{l}\text { ·現状の延長線上にある } \\
\text { 課題すら処理されない }\end{array}$ \\
\hline & & 往两KF: 0000 & 供唡KF: 0000 \\
\hline & & 很雨DF: 0000 & 徒西DF: 0000 \\
\hline
\end{tabular}

図 35 フォワード SP : 再生医療ツール : 新パラダイムの追求における将来シナリオ

\section{2-2-12. セクター軸 : 個別化医療}

過去事例 : 個別化医療・ツール側では、薬事承認事例が存在する診断薬 DNA チップについて、 次世代医療機器評価指標（開発ガイドライン、薬事ガイドライン）及び技術標準としてのISO を 選択し、詳細なルールマップの作成、時系列解析、境界組織の同定し(文献(9))、ISO マネジメン トモデルを構築した（国際ルール化 G との共通部分）。対価設定という観点から、診断薬 DNA チ ップとビーズの比較研究を事例研究として取り上げ、2000 点にキャップしたことによる影響の評 価を実施し、今後の診断のマルチプレックス化における対価設置における政策課題の抽出を行っ た(文献(23))。

個別化医療・創薬側では、日本側でのルール組成のための研究開発活動として実施された顕著 な制度やシステムは存在せず、pre-regulatory space における情報収集事例として、米国の

Voluntary Genomic Data Submission を取り上げ、分析を実施した。また、個別医療におけるプ レイヤーは誰かという問題もあり、個別化医療における企業の能力についても検討した(論文(1))。

バックワード・シナリオプランニング : 日本が主導した ISO16578 成立におけるバックワード $\mathrm{SP}$ を実施にあたっては、理想モデルと過去のギャップを分析した(図 36)。日本勢の DNA チップ における技術的な強みの認識は On Process 段階に入って初めてなされたこと、対象市場の設定は 医療をターゲットとしつつも食品から着手されたのは、日本の ISO のサポート体制が脆弱であつ たため、動きやすい食品からスタートした点にあった。日本が国際規格の組成を主導する場合求 められる政策課題の抽出を実施した。要因は全て必要条件であり、五月雨型のシナリオとなる（図 
37)。政策支援は、3 段階ともに想定され、ISO のキックオフの促進、英語対応、ISO 連結のため の戦略研究の支援である。

フォワード・シナリオプランニング : 未来事例としては単一項目診断から同時多項目診断（マ ルチプレックス）のシフトを取り扱い、個別化医療・創薬と個別化医療・デバイスは診断と治療 が一体化して進展していくことが予想されることから、個別医療ツールと個別医療創薬は統合し た。特定の治療手段において、個別化医療がどのように適用され得るのかという点に関しては、 乳癌治療における個別化医療の実際を、医療費効率化という観点から検討した。

個別化医療の全体シナリオとしては、個別化医療の進展に対する大規模な研究開発費の投入が ロジックとして成立するための条件として特定の技術要素を考慮するよりも技術が実現する結果 を重視し「医療効率をあげるイノベーション政策」が重要であるとの判断からこれを第一のシナ リオ分岐とし、医療ビックデータの活用が可能になる条件として、各種データの利用に関する国 民的合意形成とそのための技術的手段が提供されるかという観点から、「プライバシーと医療費削 減のトレードオフを国民が受け入れるか」をシナリオ分岐とした（図 38）。

\begin{tabular}{|c|c|c|}
\hline Before Process & On Process & After Process \\
\hline $\begin{array}{l}\text { Rule Target Validation } \\
\text { For Innovation }\end{array}$ & Innovation to Standard & Standard to re-innovation \\
\hline $\begin{array}{l}\text { Domestic Kick-off } \\
\text { (国内合意を得られるか) } \\
\text { Market Identification } \\
\text { (医療か食品か) }\end{array}$ & 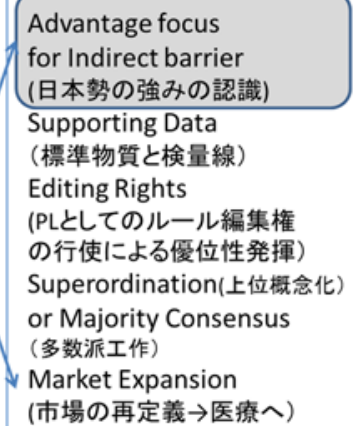 & 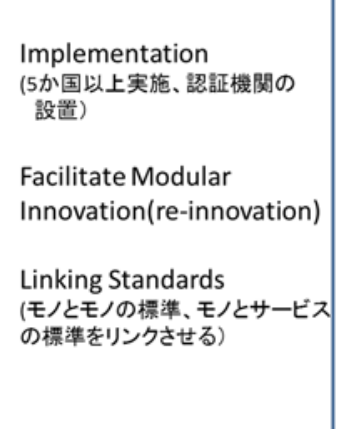 \\
\hline
\end{tabular}

図 36 バックワード SP 要因分析 : 日本主導 ISO16578 のモデルによる分析

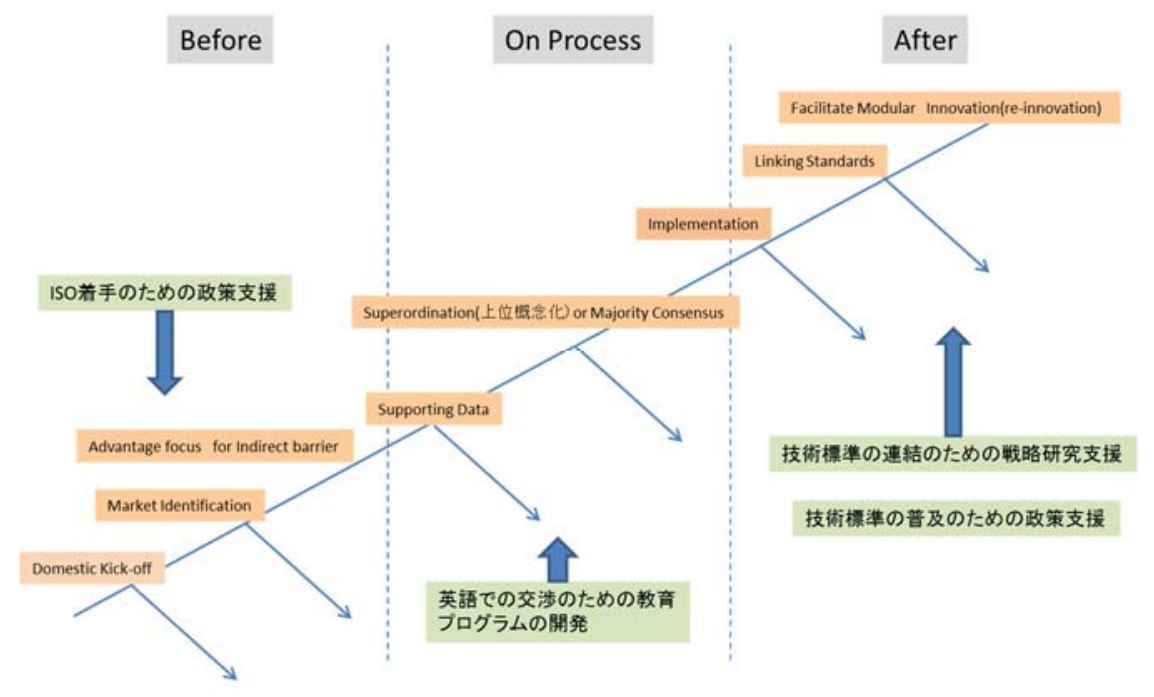

図 37 バックワードSP : 日本主導 ISO16578 と政策誘導 
【本研究の成果発表】

P-(2) Haruya, M., Kano, S. (2015), A New Look at the Corporate Capability of Personalized Medicine Development in the Pharmaceutical Industry, R\&D Management, Volume 45, Issue 1 , pages 94-103

（23）松岡修，山中隆幸，加納信吾，「検査の価值評価とイノベーション 子宮頸がんウィルス検査 の事例研究」，日本 MOT 学会 2014 年度年次研究発表会要旨集 2015 年 3 月 14 日

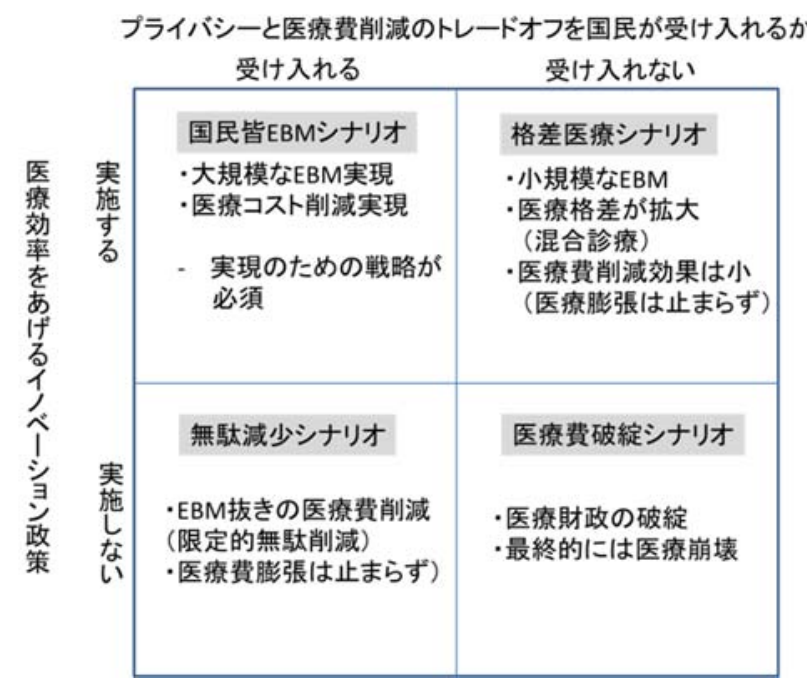

図 38 個別化医療実現にむけた将来シナリオ

\section{3. 研究開発成果}

\section{3-1. 成果の概要}

1) フォワード・シナリオプランニングから出てくる課題

また、フォワード・シナリオプランニング（FSP）から出てくる課題としては、想定したシナ

リオ分岐から技術標準、薬事規制の整備上の問題だけを抽出すると、図 39 のようになる。

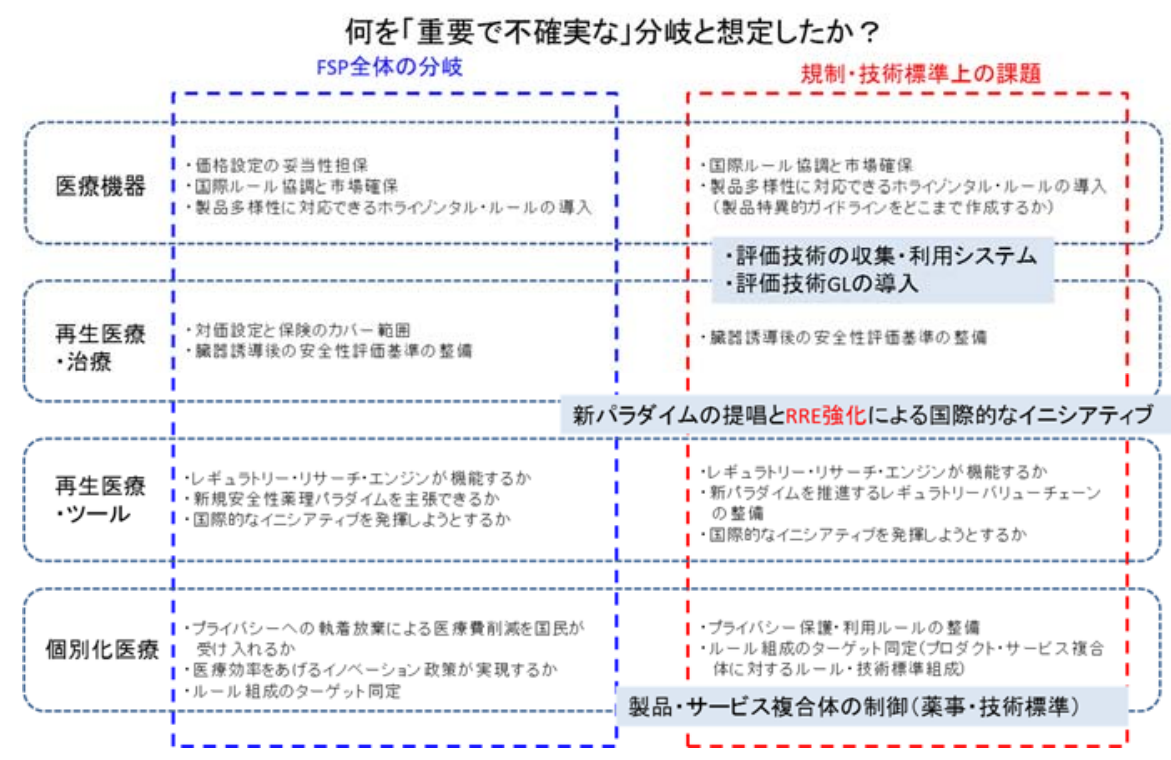

図 39 各セクターのフォワード SP の分岐一覧と政策対応 
2 ） セクター軸・機能軸から出てくる共通課題と政策提言の種類

セクター別・機能別の分析結果から得られる共通の課題を整理しておく。これらは政策課題に 転換されて、ターゲットとなるステークホルダーに提案される。

ます、本研究の結果を別の視点で整理すると、3つの課題が浮かび上がってくる。

第一にメンバーの議論を通じて確認されたのは、レギュラトリー・サイエンスに関する概念が 受け手によって異なっており、レギュラトリー・リサーチの国策上位置づけが不明確で、資金供 給上の問題が生じている点にある。また、レギュラトリー・サイエンスとイノベーターのサイエ ンスの違いを理解しないまま、両者を同じグラントで競合させるエラーも起きており、ファンデ イング・システムを分離した上で、両者の協業を促す必要がある。

第二に、レギュレーションを巡る構造上の問題である。レギュレーションは、DDT の部分で見 たように、本質的に評価技術の評価、ルールを作成するルール、ガイドラインをつくるガイドラ インといった 2 重構造をとっており、これを前提にした、システムをデザインする必要がある。 現状では日本はこの構造をとっておらず、また、レギュレーター自身がレギュレーションの政策 バリューチェーンをコントロールするためには、技術予測の段階から政策手段を保有している必 要があるが、単発的な技術予測と優先順位付けを実施するケースはあっても、構造化されていな い点も初動を遅らせる原因になっていると考えられる。また、ひとつの技術分野や製品分野にお ける政策バリューチェーンの連続性が担保されておらず、ヒトの移動とともにアセットが消失す るケースが多く、活動の連続性を維持するための仕組みが必要となっている。

第三に、ルールの作成に関与寸るのは、レギュレーターだけでなく、イノベーターの積極的な 関与が必要だが、技術標準の策定において企業側の関与が経営課題となっていないなどのマイン ドの問題も指摘されている。またレギュレーター側でも、政策バリューチェーンを統括するプレ イヤーが不在のため、レギュラトリー・リサーチとオペレーションの連動性が低く、目標設定が 行いにくい状況にあることが課題として指摘できる。

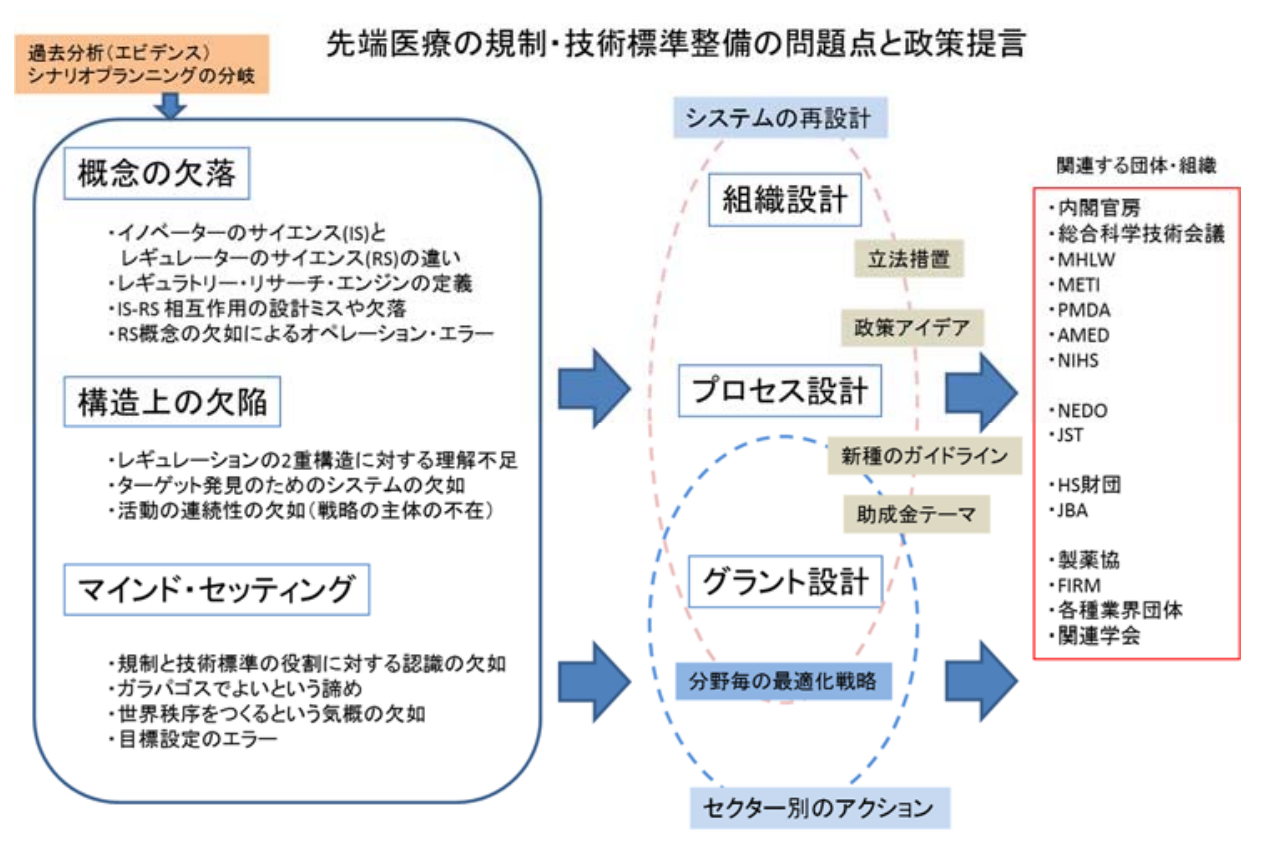

図 403 つの課題・政策提案の種類・政策提案の構造・ステークホルダーの関係

3 ）具体的な政策提案と政策の構造・種類の対応関係

シナリオプランニングから出てくるシナリオを分岐させる「重要で不確実な要因」は、本研究 
ではそのまま、具体的な政策ターゲットであり、また上記 2 ）の3つの課題も同様に具体的な政 策テーマに変換されうる。これらは組織設計、プロセス設計、グラント設計に落とすことができ、 さらには、手段として、立法措置、政策アイデア、新種のガイドライン、助成金テーマに区分し て、各々の政策テーマがどのような手段に対応すると想定しているかを整理した（図 41）。

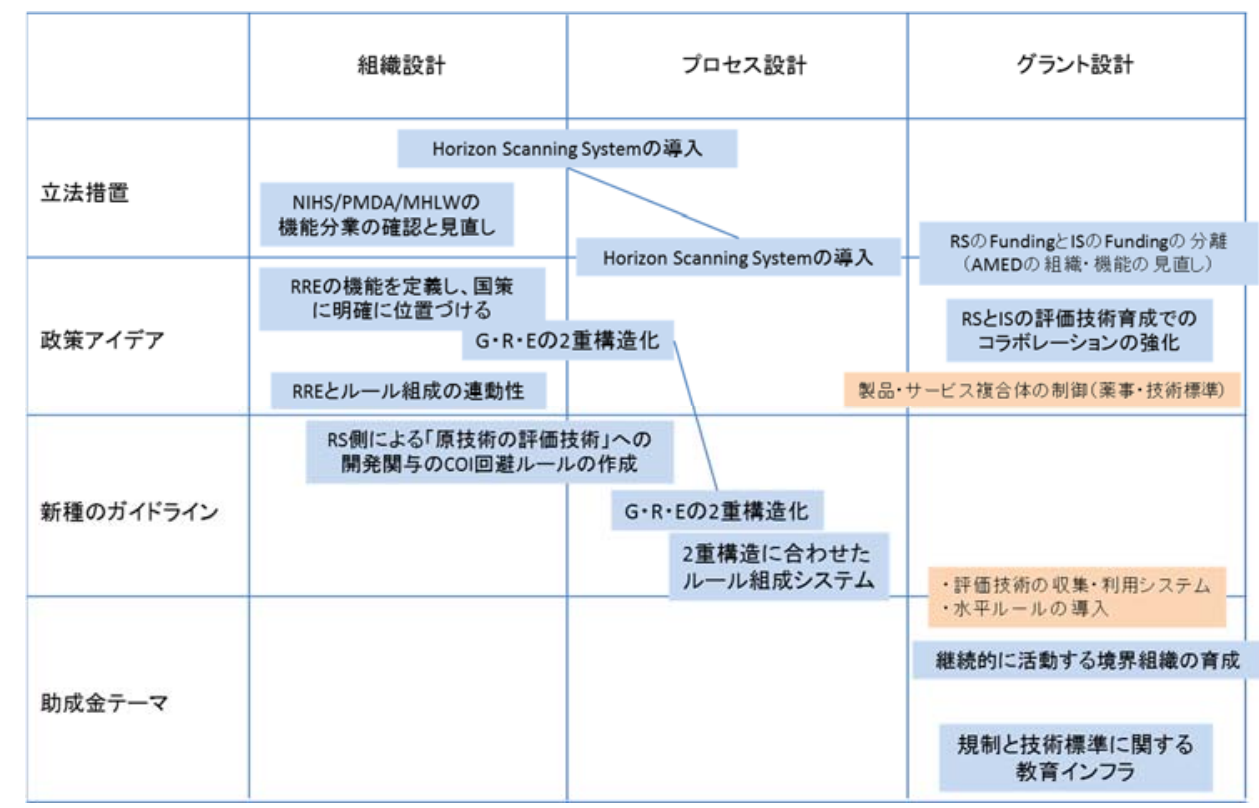

図 41 具体的な政策テーマと政策の構造・種類の対応関係

\section{3-2. 各成果の詳細}

図 41 に示す具体的な政策提案の詳細は以下の通りである。提言先となる対象は、直接的には、 技術標準を担当する METI 及び産業総合研究所、薬事規制を担当する NIHS-PMDA-MHLW であ り、これらを統括する内閣府及び現在、医療の研究開発のファンディング・エージェンシーであ る AMED であり、間接的には薬事規制と技術標準のユーザーである民間企業である。

\section{3-2-1．薬事規制・技術標準整備のための技術予測システムの設定}

政策バリューチェーンの最上流に位置する、技術予測（あるいは Horizon Scanning）と優先順 位付けを実施するシステムを整備すること、これにより薬事規制や技術標準を新技術の出現に迅 速に対応したルール整備が実現する。立法措置を伴う制度化から、グラントデザインまで手段は 多様に想定できるが、予測のための手法、技術分類の手法の継続的な開発を伴うため、恒常的な 制度が望まれる。

\section{3-2-2. ルールの研究開発の強化とそのためのファンディング構造・組織設計の見直し}

ルールの研究開発を強化することにより、日本発の技術に対して独自に審查基準や技術標準を 迅速に整備することを可能にする。このためには、現在 AMED レギュラトリー・リサーチに対す るファンディング・システムとイノベーションに対するファンディング・システムから独立させ ることにより、独立に実施する部分と共同で実施する部分を明確に分けることができ、混線によ る混乱を回避すると同時に共同プロジェクトの位置づけを明確にすることができる。また、国立 医薬品衛生研究所、PMDA、厚生省における組織・機能分担を見直し、厚生省内外へのファンデ イング・システムをレギュラトリー・リサーチの能力向上と資源確保の観点、及び海外に対する 
レギュラトリー・イニシアティブの発揮という観点から、最適化する。立法措置を伴うことも想 定される。

\section{3-2-3． 評価技術の強化と評価技術のためのガイドラインの導入}

医療機器、再生医療、医薬品の全分野で、新規技術や新規製品カテゴリーの評価に必要な評価 技術を審查に利用できるようにする、汎用的な評価技術のためのガイドラインを整備し、評価技 術のゴールを設定すること。これにより、原技術とその評価技術が出現した場合に、迅速にそれ らを審査に組込み、技術標準の作成に用いることを可能にする。特に、再生医療では、幹細胞や 幹細胞から誘導された臓器・器官の安全性評価技術の強化が重要との認識は政策立案者の間でも 強く、評価技術のための汎用的なガイドラインは既に米国で DDT や MDDT という形で導入され ているだけに、我が国においても迅速に導入する必要がある。新種のガイドライン導入のための 研究会設置が必要である (グラントによる調査研究事業でも可)。

\section{3-2-4. レギュレーションの 2 重構造のシステム化}

ソフトロー、ハードローに拘ることなく、薬事審査において製品特異的なガイドライン作成の ためのガイドライン（ガイドライン・オブ・ガイドライン）や技術非特異的な評価技術ガイドラ インを整備し、ガイドラインをより迅速に作成できるようにすること、合わせてその作成プロセ スを明示することにより、製品技術や製品の評価技術の保有者に対して透明性とインセンティブ を与えることが求められる。アウトリーチでは、政策立案者側からも欧州と米国では定義されて いる Good Guideline Practice に相当するものについては整備の必要性を感じているとのコメン トがあった。

\section{3-2-5. 継続性のある境界組織のデザインと強化}

日本の人事システムの特徵である定期的な人事異動による、経験知と人的ネットワークの喪失 の弊害を防ぐため、専門家の継続的なコミットメントの確保とそのネットワークを維持し、次世 代の課題への対応を可能にするイノベーターとレギュレーターをつなぐ境界組織を分野別の強化 すること。境界組織の安定性と継続性を確保するため、シングルタスクではなく、マルチタスク 型のシンクタンク機能を持つ集団を育成すること。グラント設計により、対応可能である。

\section{3-2-6. 製品・サービス複合体の制御}

個別化医療における製品と検查サービスの関係、人工知能やビッグデータを用いることが含ま れるような製品とサービスの組合せにおいては、薬事規制と技術標準の両方を目的に対して、同 時的に組成していくことが必要であり、製品とサービスを複合体として制御していく必要が生じ ている。制御する目的に対して、状況に応じて薬事規制で担保するか、技術標準で担保するかの 選択も重要であり、技術標準間のリンケージ、薬事規制・技術標準間のリンケージ、薬事規制間 のリンケージを産業戦略として立案可能とするだけの俯瞰的な知識と経験が必要であり、連結に 基づく技術的な優位を発揮するための理論構築と戦略構築を支援するグラント制度が必要である。

\section{3-2-7. 薬事規制と技術標準に関する教育インフラの充実}

企業における技術標準の担当者の位置づけと意識が高めるための教育カリキュラムが求められ る。ビジネス教育の一環として位置づけるためには、専門職大学院やビジネススクールでのカリ キュラム強化のために助成金制度や関連学会への補助、語学問題に対応できる高度な英語教育な どのカリキュラム編成に助成金をつけるなどの対応が想定される。 


\section{3-3. 学術的成果、人材育成やネットワーク拡大への貢献等}

\section{3-3-1. 学術的成果}

・レギュレーションの政策バリューチェーンの全体プロセスを初めて定義したこと。これにより イノベーターとレギュレーターの相互作用をプロセス毎に記載することを可能としたこと。加 えて、全体プロセスを国際ルールが先にくる Outside-in と国内ルールが先にくる Inside-out に区分して定義することにより、双方のプロセスを比較可能としたこと。

・レギュレーション・フロンティア概念により、レギュレーションの組成限界（薬事法的なポジ ティブリストでの制御限界）を提案したことにより、レギュレーターとイノベーターの相互作 用を軌道として描くことを可能とし、薬事法準拠と医師法・医療法準拠で異なる軌道を描くこ とに初めて成功したこと。これまでの Regulatory Space を定義する研究は、これまでダイナミ ックな状態定義と図式化に失敗しており、技術開発の進展と規制整備のための準備活動の進展 の双方を考慮しながら、しかも時系列的に変動するレギュレーションの対応限界を想定したダ イナミックな状態定義を可能としたこと。

・再生医療のガイドラインの内容を統一基準で初めて日米欧の国際比較したこと。

・評価技術のためのガイドラインとガイドラインのためのガイドラインが、イノベーターのサイ エンスからレギュレーターのサイエンスへの分離過程で必須であることを指摘したこと

・ISO のマネジメントモデルを一般定義で初めて提示したこと。

・薬事規制の整備における境界組織の機能を高い分解能をもつて解析可能とする分析フレームワ ークを提示したこと。

・レギュラトリーサイエンスのイノベーターサイエンスからの分離過程をテキストマイニングを 用いて、レギュレーションの内容が含まれる程度として、初めて定量的に観測したこと。

・ガイドラインに引用されるガイドラインと技術標準の引用分析を行い、個々のガイドラインの 相対的な関係をはじめて定量化し、ガイドラインの引用分析によるプロファイリングに道筋を つけたこと。

\section{3-4. 成果の発展の可能性}

・安全性薬理試験の新パラダイム提唱に向けた境界組織のマネジメントプログラムの作成 境界組織を主語にしたシナリオ・プランニングを実施し、日本発のパラダイム提唱のための方 策を検討する。

・日本における評価技術のガイドラインとルール・オブ・ルールの導入における条件検討 評価技術のガイドラインと一般的なガイドライン・オブ・ガイドラインは、制度設計上整合を とる必要があり、そのための米国における運用状況を比較対照として、日本版を設計していく 必要がある。

・製品・サービス複合体の制御のための薬事規制・技術標準のリンケージ解析

製品・サービス複合体は、知的財産権、技術標準、薬事規制の 3 つの視点から検討する必要が あり、特に個別化医療や再生医療では検討が必要である。

・先端医療の技術予測システムのための技術分類に関する研究

Horizon Scaninng などの技術予測から下流へのプロセスで常に問題になっているのは、あたら 行く出現してくる技術に対する分類概念であり、各国で分類概念が異なるために国際比較も難 しい状態にある。このため、技術予測のための技術分類を検討する必要がある。 


\section{4. 関与者との協働、成果の発信・アウトリーチ活動}

\section{4-1. 研究開発の一環として実施した会合・ワークショップ等}

\begin{tabular}{|c|c|c|c|c|}
\hline 名 称 & 年月日 & 場 所 & \begin{tabular}{c|} 
規模 \\
(参加人数等) \\
\end{tabular} & 概 要 \\
\hline $\begin{array}{l}\text { 個別化医療の将来像 } \\
\text { 検討のための特別研 } \\
\text { 究会 }\end{array}$ & 2015/11/16 & $\begin{array}{l}\text { 伊藤国際学術研究 } \\
\text { センター }\end{array}$ & $\begin{array}{l}25 \text { 名 } \\
\text { クローズド }\end{array}$ & $\begin{array}{l}\text { 個別化医療に関する将来 } \\
\text { シナリオの検討 (理研林崎 } \\
\text { 先生講演とそれを元にし } \\
\text { たメンバーとのブレイン } \\
\text { ストーミング) }\end{array}$ \\
\hline \begin{tabular}{|l|} 
「先端医療を対象と \\
した規制・技術標準整 \\
備のための政策シミ \\
ユレーション」インタ \\
ラクティブ・ワークシ \\
ヨップ \\
\end{tabular} & $2016 / 3 / 1$ & $\begin{array}{l}\text { 伊藤国際学術研究 } \\
\text { センター }\end{array}$ & \begin{tabular}{|l|}
32 名 \\
クローズド
\end{tabular} & $\begin{array}{l}\text { AMED、経済産業省生物 } \\
\text { 化学産業課、技術標準課な } \\
\text { ど、ステークホルダーを対 } \\
\text { 象とした、シナリオプラン } \\
\text { ニングの結果や今後望む } \\
\text { テーマに対する意見聴取 }\end{array}$ \\
\hline $\begin{array}{l}\text { SciREX セミナー:「イ } \\
\text { ノベーションとレギ } \\
\text { ュレーションの共進 } \\
\text { 化」 }\end{array}$ & $2016 / 10 / 25$ & $\begin{array}{l}\text { 霞ヶ関ナレッジス } \\
\text { クエア エキスパー } \\
\text { 卜俱楽部 }\end{array}$ & $\begin{array}{l}20 \text { 名 } \\
\text { セミオープ } \\
\text { ン }\end{array}$ & $\begin{array}{l}\text { 政策担当者等のステーク } \\
\text { ホルダー(METI、MHLW, } \\
\text { PMDA)を招いて、結果説 } \\
\text { 明と意見交換。アウトリー } \\
\text { チも兼ねる。 }\end{array}$ \\
\hline
\end{tabular}

\section{4-2. アウトリーチ活動}

4-2-1. 主催したイベント

(1) 名称：第 3 回 JMAC シンポジウム バイオ市場拡大戦略としての国際標準化（JMAC と 当プロジェクトの共催国際シンポジウム)、開催年月日 : 2015/11/20、場所 : 東京ウィメンズ プラザ地下 1 階ホール、規模 : 200 名(オープン)、概要 : 当プロジェクトから 4 名の GL（中 野、中江、関野、加納）がプレゼンテーションし、技術標準と薬事規制の整備が企業にとつ ての所与の外部環境ではなく、経営課題として関与していく必要性を参加者に喚起した。

\section{4-2-2. 書籍、DVD など発行物}

(1) Shingo Kano, "Technology Provider and Receiver Interactions: The Capability Threshold Concept and Its Application to Technology Assessment,", KIT Scientific Publishing, Karlsruhe, p147-161, 2016

\section{4-2-3. ウェブサイト構築}

（1） 情報共有・整理のための内部メンバー向けのサイトを構築

\section{4-2-4. 招聘講演}

（1）加納 信吾 (東京大学)、「再生医療における国家プロジェクトと技術パラダイムシフト」、 国家プロジェクトの変遷と技術のパラダイムシフト（主催：商工会館 協力：独立行政法人 経済産業研究所、日本MO T学会)、場所：商工会館、2014 年 10 月 17 日、参加者 : 60 名 


\section{5. 論文、特許等}

\section{5-1. 論文発表}

\section{5-1-1． 查読付き（4 件)}

(1) Haruya, M., Kano, S. (2015), A New Look at the Corporate Capability of Personalized Medicine Development in the Pharmaceutical Industry, R\&D Management, Volume 45, Issue 1, pages 94-103

(2) Kuni Itoh and Shingo Kano (2016), Comparison of international guidelines for regenerative medicine: knee cartilage repair and replacement using human-derived cells and tissues, Biologics, Volume 44, Issue 4, July, Pages 267-270

(3) Hayashi,Yuko; Kano,Shingo(2015) "Policy value chain of making regulation in ICH S7B/E14", "12th International Conference on Innovation and Management"

(4) Shingo Kano (2016), Interaction Analysis between Innovation and Regulation - The concept of regulatory science as a process (RaaP) and its applications -, ID: 16R0141, PICMET'16 Conference Paper

5-1-2. 查読なし（0 件 $)$

\section{5-2. 学会発表}

5-2-1．招待講演（国内会議 1 件、国際会議 0 件）

(1) 加納信吾, MOT 研究における未来研究手法の組込み -シナリオプランニング技法利用上の課 題-，日本 MOT 学会 2015 年度年次研究発表会要旨集 2016 年 3 月 12 日

5-2-2. 口頭発表（国内会議 17 件、国際会議 6 件）

(1) 加納信吾(東大), 林裕子(山口大), 中野壮陛(医療機器センター),「レギュレーションフロンティ ア概念に基づく先端医療のルール組成過程の解析」, 2013 研究・技術計画学会要旨集 28:755-758、研究技術計画学会、於政策研究大学院大学、2013 年 11 月

（2）林裕子(山口大)，加納信吾（東大），「境界組織に着目したレギュレーターとイノベーター間 相互作用の分析フレームワーク構築」, 日本 MOT 学会 2013 年度年次研究発表会要旨集、於 東京理科大学、 2014 年 3 月 15 日

（3）林裕子(山口大), 加納信吾(東大)，「戦略的レギュレーションがもたらすイノベーション：先端 医療を事例として」, 日本 MOT 学会 2013 年度年次研究発表会要旨集、於東京理科大学、2014 年 3 月 15 日

（4）伊藤紗也佳(東大), 加納信吾(東大), 「再生医療分野におけるルール組成初期過程のフレームワ 一ク分析」, 日本 MOT 学会 2013 年度年次研究発表会要旨集、於東京理科大学、2014 年 3 月 15 日

(5) Shingo Kano(東大), How innovation and regulation interact? A new definition of regulatory space and its implication for technology assessment, 科学技術イノベーション政 策のための科学 研究開発プログラム 第 3 回国際ワークショップ "TA under Pressure", 於 JST 市ヶ谷、July 11th 2014

(6) Shingo Kano(東大), Sayaka Ito(東大), How technology forecasting affects the jurisdiction of technology - A case of Japanese medical device forecasting survey -, Technology 
Assessment in East Asia: Experiences and New Approaches, 2nd European TA Conference: The Next Horizon of Technology Assessment, Berlin, Germany, February 25, 2015

(7) Shingo Kano(東大), The Concept of Regulatory Frontier as a Boundary of Jurisdiction in Medicine: A Case of Regenerative Medicine in Japan, PaperID_14A0105, PICMET2014, Kanazawa,

（8）加納信吾(東大),「イノベーションとレギュレーションの相互作用-先端医療のルール組成を事 例として」, 日本 MOT 学会 2014 年度年次研究発表会要旨集, 於東京大学、 2015 年 3 月 14 日

（9）木戸舞(東大)，山中隆幸(東大)，中江裕樹(JMAC)，加納信吾(東大)，「先端医療における日本主 導の技術標準形成過程の分析〜ISO16578 の事例研究〜」，日本 MOT 学会 2014 年度年次研 究発表会要旨集、於東京大学、2015 年 3 月 14 日

（10）伊東久仁(東大)，山中隆幸(東大)，加納信吾(東大)，「日米欧 再生医療関連ガイドラインの国 際比較 ガイドラインの分析フレームワークの構築」, 日本 MOT 学会 2014 年度年次研究発 表会要旨集、於東京大学、2015 年 3 月 14 日

（11）伊藤紗也佳(東大)，加納信吾(東大)，「技術予測における技術分類概念が医療のルール策定に 与える影響の解析〜次世代医療機器評価指標ガイドラインを事例として〜」, 日本 MOT 学会 2014 年度年次研究発表会要旨集、於東京大学、2015 年 3 月 14 日

(12) 林裕子(山口大)，加納信吾(東大)，「医療分野の国際ルール組成における境界組織の分析 -ICHS7B/E14 を事例として-」, 日本 MOT 学会 2014 年度年次研究発表会要旨集、於東京大 学、2015 年 3 月 14 日

（13）林裕子(東大), 加納信吾(東大),「先端医療のレギュレーション策定における媒介機能の分析」, 2015 研究・技術計画学会要旨集 30：15-19,於早稲田大学、2015 年 10 月 11 日

(14) 加納信吾(東大)，「レギュラトリー・イニシアティブに関する研究 - 新技術に対応したルール 組成の国際競争力の要因分析-」,2015 研究・技術計画学会要旨集 30: 11-14, 於早稲田大学、 2015 年 10 月 11 日

(15) 石田瑞(東大), 加納信吾(東大)，「先端医療におけるレギュラトリーサイエンスの発生過程に 関する研究」, 2015 研究・技術計画学会要旨集 30: 229-232, 於早稲田大学、2015 年 10 月 11 日

(16) Shingo Kano(東大), Interaction Analysis between Innovation and Regulation - The concept of regulatory science as a process (RaaP) and its applications -, 16R0141, PICMET'16 Conference、於ハワイ、2016 年 9 月 6 日

（17）林裕子（山口大学）“Policy value chain of making regulation in ICH S7B/E14”，第 12 回 International Conference on Innovation and Management, Wuhan University of Technology(中国) 2015 年 11 月 21 日(土)

(18) 加納信吾(東大), 先端医療の薬事規制におけるルール・オブ・ルールに関する研究，第 31 回 研究・イノベーション学会年次学術大会 $2 \mathrm{I} 03$, 於青山学院大学、2016 年 11 月 6 日

(19) 木戸舞(東大), 加納信吾(東大), 薬事規制と技術標準のリンケージ解析 - 次世代医療機器・再 生医療等製品評価指標を事例に-, 第 31 回研究・イノベーション学会年次学術大会 $2 \mathrm{I} 04$, 於 青山学院大学、 2016 年 11 月 6 日(予稿集提出 9 月 30 日)

(20) 永倉千沙(東大), 加納信吾(東大), 先進医療におけるレギュラトリーパスの選択に関する研究 -癌細胞免疫療法を事例として-, 第 31 回研究・イノベーション学会年次学術大会 $2 \mathrm{I} 05$, 於青 山学院大学、2016 年 11 月 6 日(予稿集提出 9 月 30 日)

(21) 林裕子(山口大), 加納信吾(東大), 政策バリューチェンにおける媒介組織・機能の変遷, 第 31 回研究・イノベーション学会年次学術大会 $1 \mathrm{~A} 02 、 2016$ 年 11 月 6 日(予稿集提出 9 月 30 日) 
(22) Yuko Hayashi(山口大), US-Japan Comparative study on strategic regulation of new Biomedical Technologies - A case study on Microarray, International Conference on Innovation and Management, Nov. 17-19, 2014, Vaasa, Finland

（23）松岡修(東大)，山中隆幸（東大），加納信吾（東大），「検査の価值評価とイノベーション 子 宮頸がんウィルス検査の事例研究」, 日本 MOT 学会 2014 年度年次研究発表会要旨集 2015 年 3 月 14 日

5-2-3. ポスター発表（国内会議 0 件、国際会議 0 件） なし

\section{6. 研究開発実施体制}

6-1. 体制

研究開発実施体制

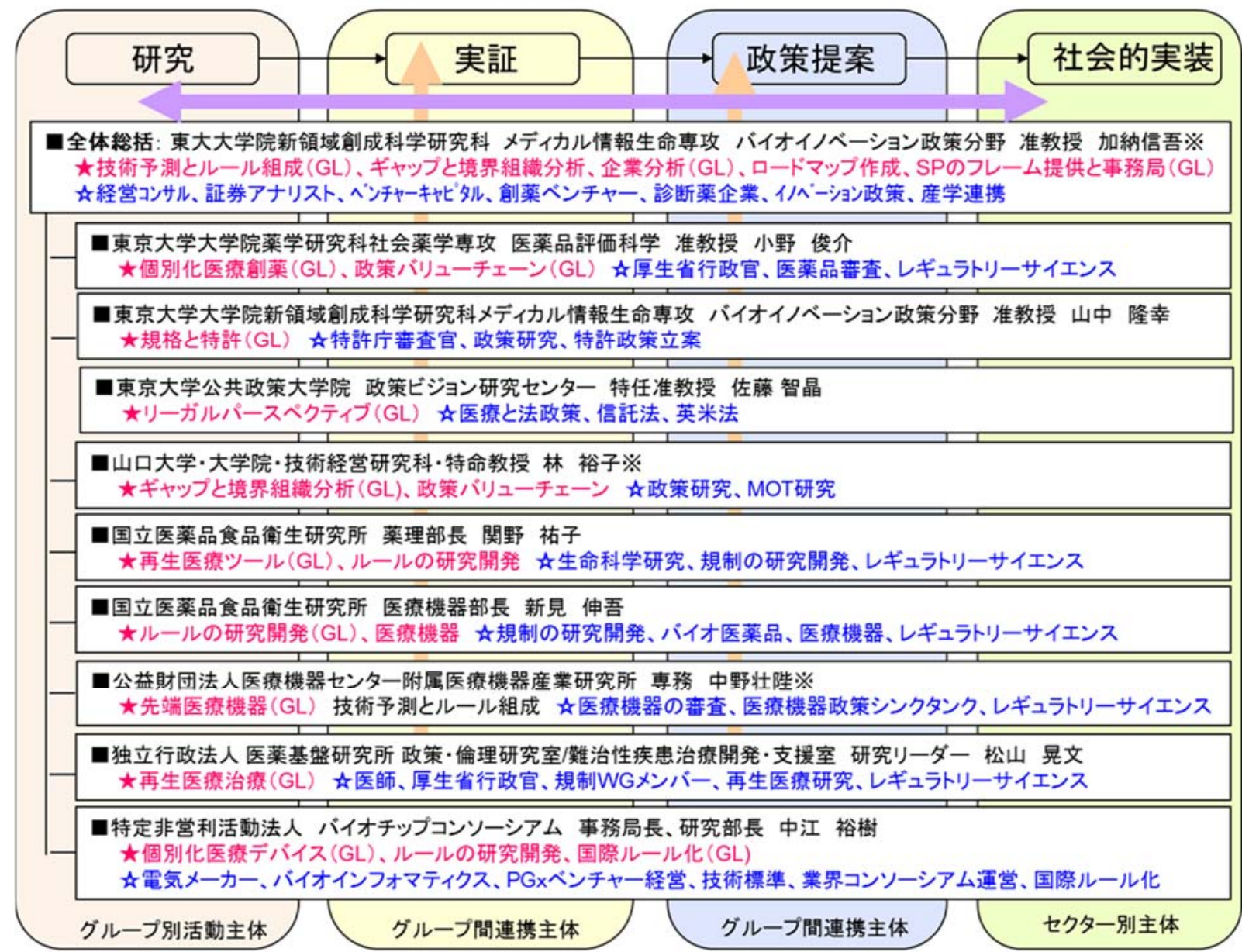

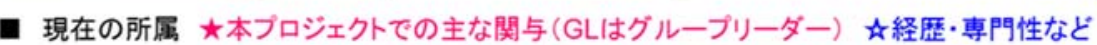

※ 科研費基盤研究(B): 先端医療分野のレギュレーションギャップ・マネジメントに関する研究(07-09)参加者

【特記事項】

研究段階では、セクター軸と機能解析軸のマトリックス型の組織設計となっており、内容的に 
オーバーラップ部分がマトリックスの各交点に存在するため、セクター軸のリーダーは機能解析 軸の作業を一部分担する形式となっている。本プロジェクトは、マトリックスのすべての交点を 網羅することは意図しておらず、選択された事例や特定の課題として認識された部分を中心に解 析を進めた。研究段階における情報収集は、若手研究者である東京大学大学院新領域創成科学研 究科の博士課程学生の参加協力により実施された。

一方、実証・政策提案・社会実装段階では、シナリオプランニングにおけるワークショップは メンバー全員がエキスパート・オピニオンの出し手となって参加し、セクター軸のリーダーはシ ナリオプランニングのセクター責任者とした。シナリオプランニングの実施にあたっては、4回 のシナリオプランニングのための勉強会を実施し、レギュラトリーサイエンスの実務家と社会科 学系の研究者の知識ギャップを埋めるための作業を要した。

研究代表者は、実証・政策提案・社会実装段階ではシナリオプランニングのワークショップ事 務局となり、シナリオプランニング特有のドキュメンテーションを担当するとともに、社会実装 段階での情報交換を主として担った。

フェーズによって異なる実施体制

研究

マトリックス型 の実施体制
実証

SP事務局による 全員参加型運営
政策提案

SP事務局による 全員参加型運営
社会的実装

SPチーム別に政策

実装の担い手との

情報交換

\section{6-2. 研究開発実施者}

末尾に掲載

\section{6-3. 研究開発の協力者 - 関与者}

末尾に掲載 